\title{
Ground-Water Geochemistry at the South Ramp Jet Fuel Leak, Diego Garcia Atoll, 1993-94
}

\section{U.S. GEOLOGICAL SURVEY}

Water-Resources Investigation Report 01-4090

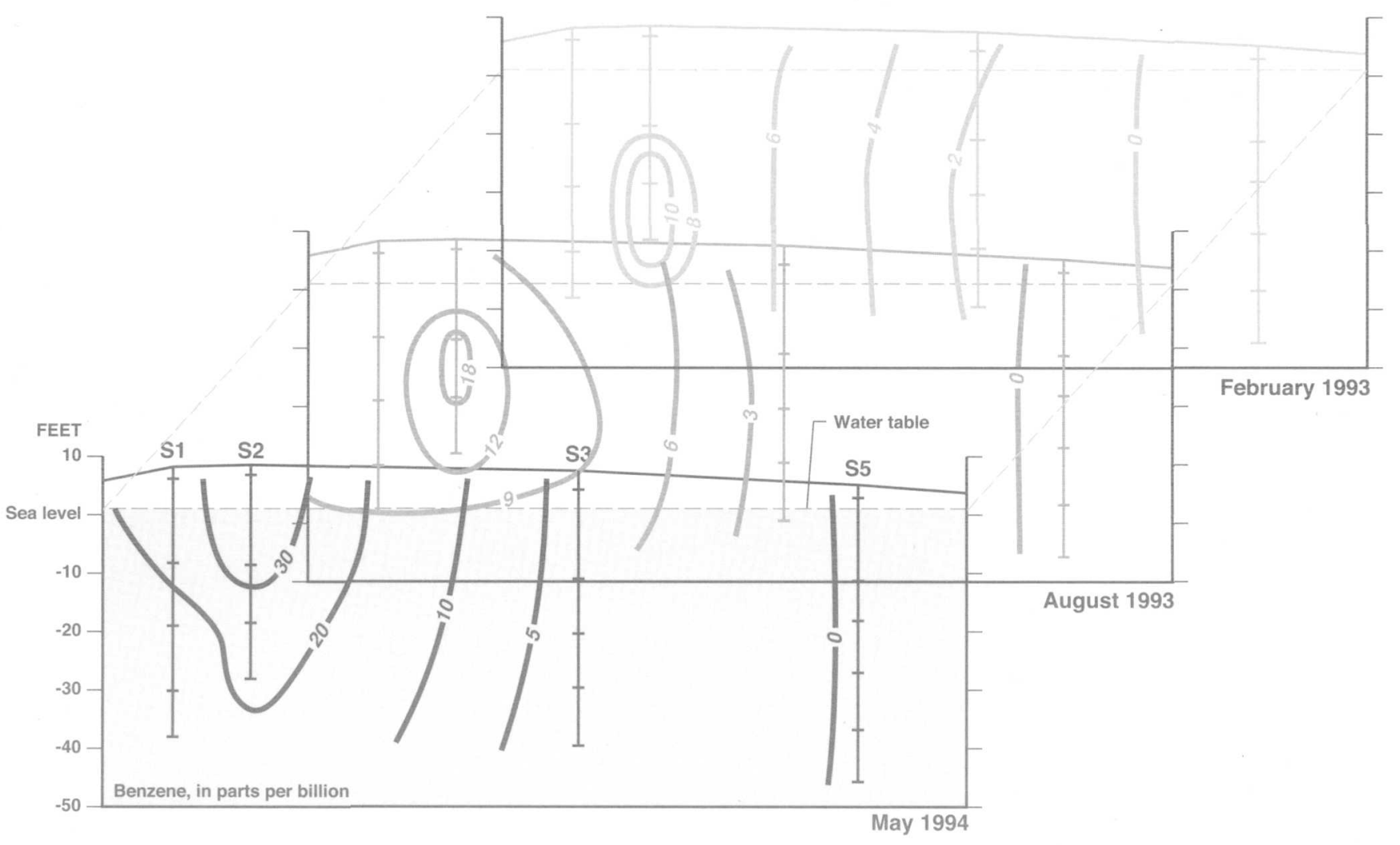

Prepared in Cooperation with the U.S. DEPARTMENT OF THE NAVY NAVY SUPPORT FACILITY, DIEGO GARCIA 
i - 


\section{GROUND-WATER GEOCHEMISTRY AT THE SOUTH RAMP JET FUEL LEAK, DIEGO GARCIA ATOLL, 1993-94}

By Gordon W. Tribble

U.S. GEOLOGICAL SURVEY

Water-Resources Investigations Report 01-4090

Prepared in cooperation with the U.S. DEPARTMENT OF THE NAVY NAVY SUPPORT FACILITY, DIEGO GARCIA 


\section{U.S. DEPARTMENT OF THE INTERIOR \\ GALE A. NORTON, Secretary}

U.S. GEOLOGICAL SURVEY

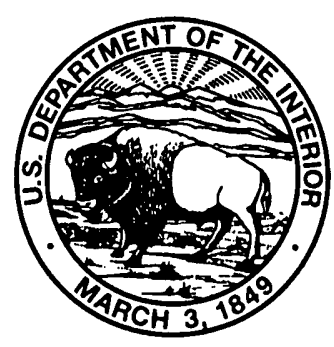

Charles G. Groat, Director

The use of firm, trade, and brand names in this report is for identification purposes only and does not constitute endorsement by the U.S. Geological Survey.

For additional information write to:

District Chief

U.S. Geological Survey

677 Ala Moana Blvd., Suite 415

Honolulu, HI 96813
Copies of this report can be purchased from:

U.S. Geological Survey

Branch of Information Services

Box 25286

Denver, CO 80225-0286 


\section{CONTENTS}

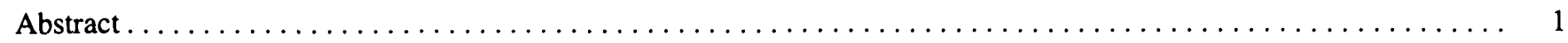

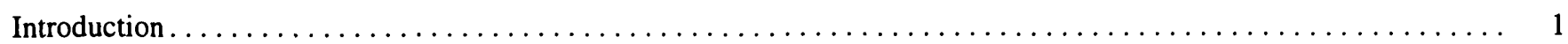

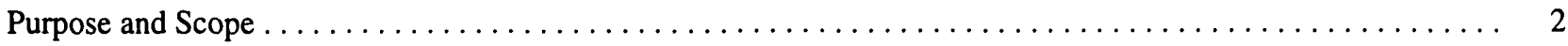

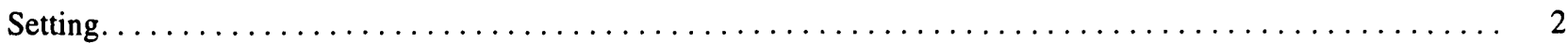

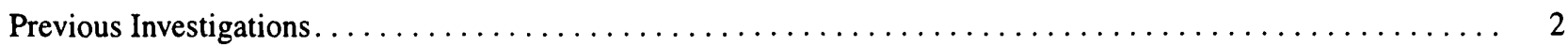

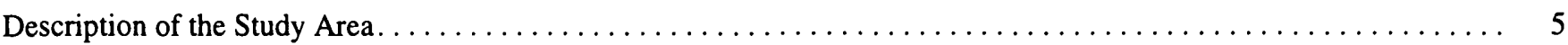

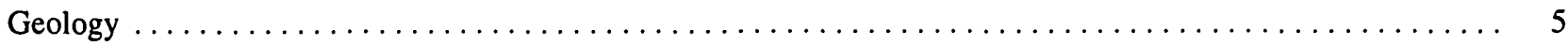

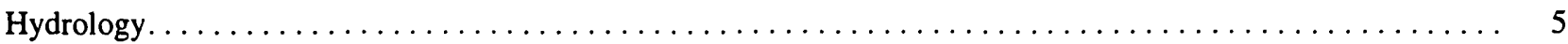

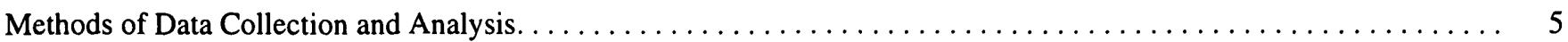

Installation and Sampling of Monitor Wells, Lysimeters, and Vapor Points . . . . . . . . . . . . . 6

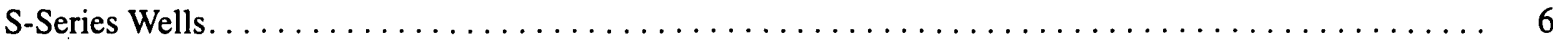

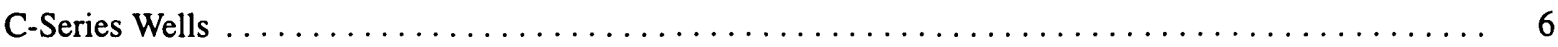

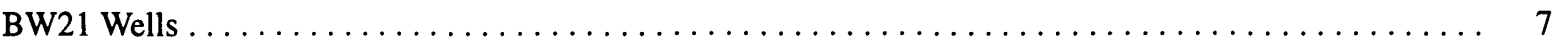

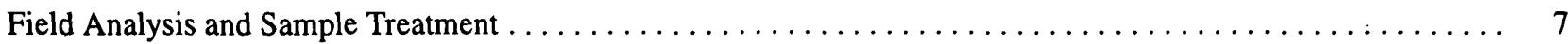

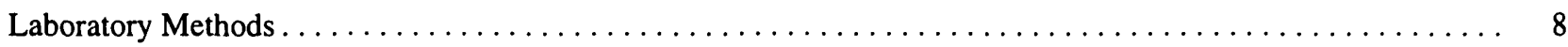

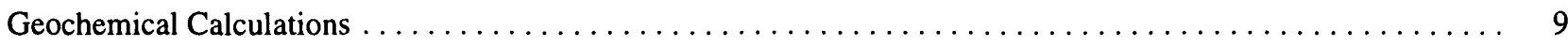

Geochemistry of Ground Water, Gases in the Unsaturated Zone, and Fuel Hydrocarbons . . . . . . . . . . . 10

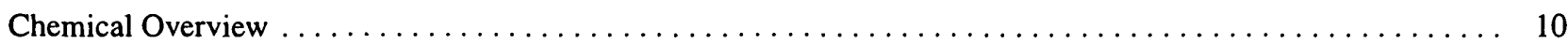

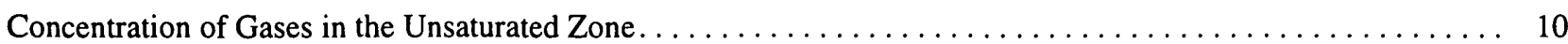

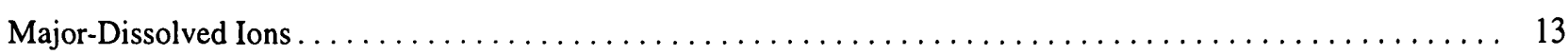

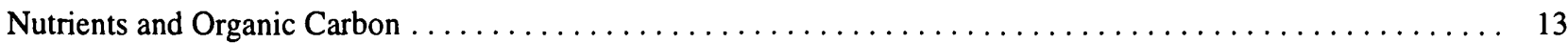

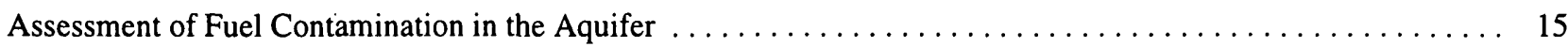

Hydrocarbons in Ground Water and Soil Vapor. . . . . . . . . . . . . . . . . . . . . 18

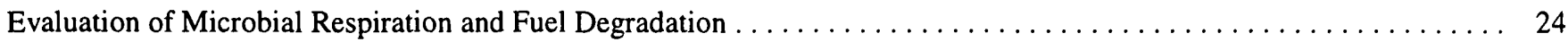

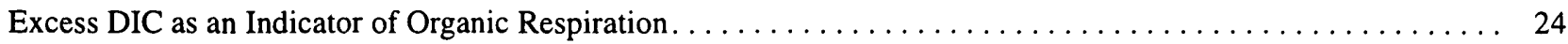

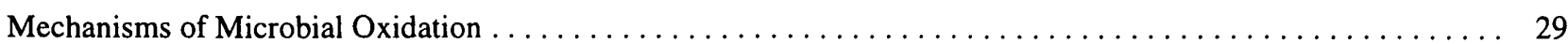

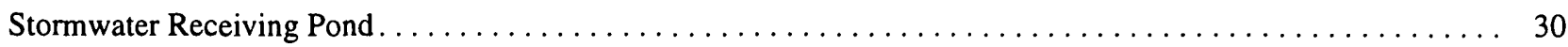

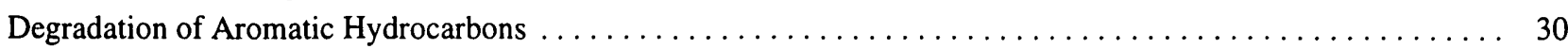

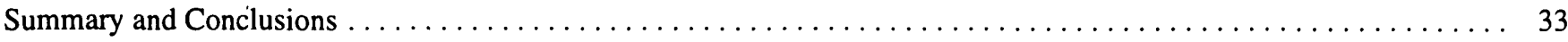

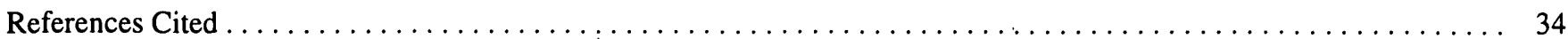

\section{Figures}

1-2. Maps showing:

1. Diego Garcia Atoll in the Indian Ocean and location of the study area $\ldots \ldots \ldots \ldots$

2. South Ramp and locations of fuel leak and monitoring wells, Diego Garcia Atoll, 1993-94. . . . . . . . 4

3. Diagram of carbon dioxide $\left(\mathrm{CO}_{2}\right)$ and methane $\left(\mathrm{CH}_{4}\right)$ concentrations in the unsaturated zone of the aquifer near the South Ramp in May 1994, as a percentage of total gas concentration, Diego Garcia Atoll, 1993-94 . . 12

4-9. Graphs showing:

4. Concentrations of dissolved sodium $\left(\mathrm{Na}^{+}\right)$, dissolved potassium $\left(\mathrm{K}^{+}\right)$, and dissolved sulfate $\left(\mathrm{SO}_{4}{ }^{2-}\right)$ compared with dissolved chloride $\left(\mathrm{CL}^{-}\right)$in ground-water samples from S-series wells and lysimeters in February 1993, August 1993, and May 1994, Diego Garcia Atoll. 
5. Concentrations of dissolved calcium $\left(\mathrm{Ca}^{2+}\right)$, dissolved magnesium $\left(\mathrm{Mg}^{2+}\right)$, and dissolved strontium $\left(\mathrm{Sr}^{2+}\right)$ compared with dissolved chloride $\left(\mathrm{Cl}^{-}\right)$in ground-water samples from S-series wells and lysimeters in February 1993, August 1993, and May 1994, Diego Garcia Atoll. . . . . . . . . . . . . . . . . . . . . .

6. Concentrations of dissolved phosphate $\left(\mathrm{PO}_{4}{ }^{3+}\right)$ and dissolved silica ( $\mathrm{Si}$ ) compared with total dissolved inorganic nitrogen $\left(\mathrm{NO}_{3}{ }^{-}+\mathrm{NH}_{4}{ }^{+}\right)$in ground-water samples from $\mathrm{S}$-series wells and lysimeters in February 1993, August 1993, and May 1994, Diego Garcia Atoll. ........................

7. Concentrations of dissolved organic phosphorus (DOP) and dissolved organic nitrogen (DON) compared with dissolved organic carbon (DOC) in ground-water samples from S-series wells and lysimeters in

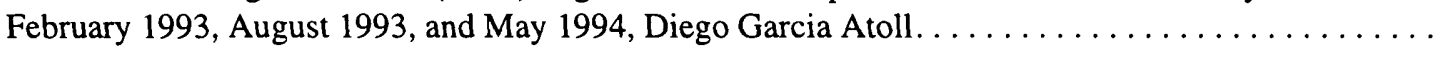

8. Relation between dissolved organic carbon (DOC) to dissolved organic phosphorus (DOP) and dissolved organic carbon (DOC) to dissolved organic nitrogen (DON) compared with dissolved organic carbon (DOC) in ground-water samples from S-series wells and lysimeters in February 1993, August 1993,

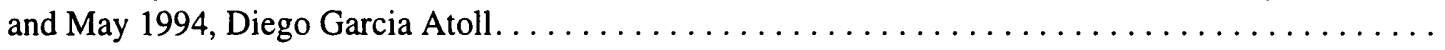

9. Relation between benzene and dissolved organic carbon (DOC) in ground-water samples from S-series wells in February 1993, August 1993, and May 1994, Diego Garcia Atoll . . . . . . . . . . . . . .

10. Hydrologic sections of benzene concentration at well sites S1, S2, S3, and S5 in February 1993, August 1993,

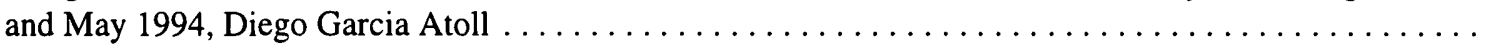

11-12. Graphs showing:

11. Distribution of charge balance calculated using WATEQ4F for ground-water samples collected in February 1993, August 1993, and May 1994, Diego Garcia Atoll . . . . . . . . . . . . . . . . . . . . . .

12. Relation between dissolved inorganic carbon (DIC) released from carbonate mineral dissolution and dissolved inorganic carbon (DIC) released from microbial respiration for ground-water samples collected in February 1993, August 1993, and May 1994, Diego Garcia Atoll . . . . . . . . . . . .

13. Hydrologic section of dissolved inorganic carbon concentration at well sites S1, S2, S3, and S5 in May

1994, Diego Garcia Atoll . . . . . . . . . . . . . . . . . . . . . . . . . . . . . . . .

Tables

1. Analytical precision, accuracy, and detection limits for selected chemical constituents in ground water from Diego Garcia Atoll, 1993-94

2. Field data and concentrations of dissolved hydrogen sulfide and oxygen in ground-water, rain, seawater,

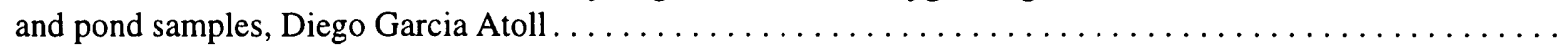

3. Concentration of oxygen, carbon dioxide, and methane in vapor samples from the unsaturated zone, Diego Garcia Atoll

4. Concentrations of major dissolved ions in ground-water, rain, seawater, and pond samples, Diego Garcia

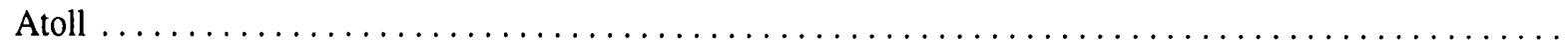

5. Concentrations of dissolved inorganic and organic nutrients in ground-water, rain, seawater, and pond samples,

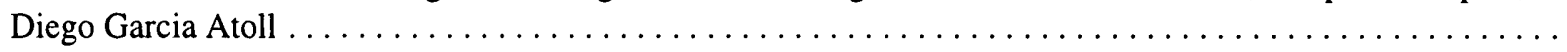

6. Approximate thickness of free-phase fuel at South Ramp wells and recovery pits, Diego Garcia Atoll .........

7. Concentrations of benzene, dissolved organic carbon, oil and grease, and total petroleum hydrocarbons in

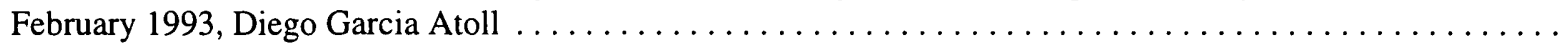

8. Concentrations of volatile organic carbon compounds in vapor and water samples, Diego Garcia Atoll ........

9. Concentrations of selected volatile organic carbon compounds found in ground water, Diego Garcia Atoll .....

10. Charge balance, saturation index with respect to aragonite, and total dissolved inorganic carbon in ground-water samples, Diego Garcia Atoll. . . . . . . . . . . . . . . . . . . . . . . . . . . .

11. Concentrations and relative percentage of three major groups of aromatic hydrocarbons in ground water, Diego

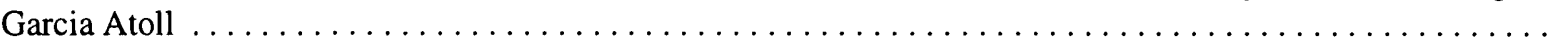




\section{Conversion Factors}

\begin{tabular}{rll}
\hline Multiply & \multicolumn{1}{c}{ By } & To obtain \\
\hline foot $(\mathrm{ft})$ & 0.3048 & meter \\
gallon $(\mathrm{gal})$ & 0.003785 & cubic meter \\
gallon per minute $(\mathrm{gal} / \mathrm{min})$ & 0.06308 & liter per second \\
million gallons per day (Mgal/d) & 0.04381 & cubic meter per second \\
mile (mi) & 1.609 & kilometer \\
inch (in.) & 25.4 & millimeter \\
\hline
\end{tabular}

Temperature is given in degrees Celsius $\left({ }^{\circ} \mathrm{C}\right)$, which can be converted to degrees Fahrenheit $\left({ }^{\circ} \mathrm{F}\right)$ by using the equation:

$$
{ }^{\circ} \mathrm{F}=1.8 \times{ }^{\circ} \mathrm{C}+32
$$

Abbreviations used in water quality descriptions:

DIC, dissolved inorganic carbon

DOC, dissolved organic carbon

DON, dissolved organic nitrogen

DOP, dissolved organic phosphorus

GC, gas chromatography

GC-MS, gas chromatography - mass spectroscopy

IR, infrared

meq/L, milliequivalents per liter

$\mathrm{mg} / \mathrm{L}$, milligrams per liter

$\mathrm{mM}$, millimoles per liter

ppb, parts per billion

ppm, parts per million

$\mu \mathrm{g} / \mathrm{L}$, micrograms per liter

$\mu \mathrm{m}$, micron

$\mu \mathrm{S} / \mathrm{cm}$, microsiemens per centimeter at $25^{\circ}$ Celsius

TPH, total petroleum hydrocarbons

UV, ultraviolet

VOC, volatile organic carbon 



\title{
Ground-Water Geochemistry at the South Ramp Jet Fuel Leak, Diego Garcia Atoll, 1993-94
}

\author{
By Gordon W. Tribble
}

\section{Abstract}

In 1991, a leak of jet fuel from an underground pipe near the South Ramp of Diego Garcia was detected. The leaked fuel contaminated part of the shallow aquifer and threatened several nearby production wells. To assess the extent of contamination and microbial degradation of fuel, a geochemical analysis was used to characterize the prevailing chemical reactions in the aquifer. Data for this study were collected from a network of wells, vapor points, and lysimeters in February 1993, August 1993, and May 1994. Chemical processes were deduced through analysis of major ions, gases, nutrients, and fuel constituents. The study determined the total amount of microbial respiration. Dissolved gases such as oxygen, hydrogen sulfide, and methane were used to provide insight into the respiratory processes of bacteria in the aquifer. In contaminated areas, the ratios of specific contaminant compounds gave a quantitative measure of the extent of aromatic degradation. Ground-water samples were anoxic, and gas from the unsaturated zone had low concentrations of oxygen. Gas samples near the contaminated area had high concentrations of methane. Dissolution of carbonate minerals and microbial oxidation of organic material, as measured by changes in geochemical indicators, were the principal reactions in the aquifer. Compared with uncontaminated sites, both processes occurred to a much higher degree at contaminated sites. The high levels of bacterial respiration at contaminated sites, compared with uncontaminated sites, showed that petroleum hydrocarbons were actively degraded by naturally occurring bacteria in the aquifer.

Petroleum hydrocarbons were found dissolved in ground water, as a vapor phase in the unsaturated zone, and floating as a free-phase layer on top of the water table. Despite the recovery of more than 134,000 gallons of fuel, substantial quantities of fuel remain in the aquifer. Benzene concentrations have shown a steady increase in both ground water and soil vapor. The ratio of benzene to more persistent aromatic compounds such as naphthalene, trimethyl benzene, and tetramethyl benzene, increased with depth in the aquifer, indicating that significant amounts of benzene were not being degraded under the reducing conditions in the aquifer.

\section{INTRODUCTION}

Diego Garcia atoll is part of the British Indian Ocean Territory and is a support base for U.S. Navy operations in the Indian Ocean. There are about 3,500 inhabitants on the island and the demand for freshwater averages 0.8 to $1.2 \mathrm{Mgal} / \mathrm{d}$. All of this water is pumped from the ground.

In May 1991, a rupture was discovered in an underground pipeline carrying JP-5 jet fuel. Fuel from this leak contaminated the soil and ground water near one of the major sources of freshwater on the island. The volume of leaked fuel is unknown. Work was initiated to recover free-phase fuel, retard the spread of fuel and contaminated ground water, and remediate the contaminated parts of the aquifer. The role of the U.S. Geological Survey (USGS) was to: (1) conduct computer simulations to aid in the containment of the contaminant 
plume and design of a fuel-recovery system; (2) monitor aquifer water levels to determine the direction of ground-water flow under different pumping scenarios; and (3) provide a characterization of chemical conditions and processes in both contaminated and uncontaminated parts of the aquifer.

\section{Purpose and Scope}

This report is part of a program to provide technical assistance to the U.S. Navy for remediation of the South Ramp fuel leak. This project started in June 1991 with a site visit and preliminary characterization following discovery of the spill (C.D. Hunt, Jr., USGS, written commun., 1991). Since 1991, trips to Diego Garcia have been conducted to install wells for collecting water samples and monitoring water levels, service the waterlevel recording equipment, and conduct water-chemistry studies. The data in this report were collected during three trips in January and February 1993, August 1993, and May 1994.

The purpose of this report is to describe the chemical characteristics of ground water near the South Ramp of Diego Garcia Atoll. This characterization includes the overall chemical composition of ground water in the shallow aquifer, the extent of chemical reactions in the aquifer, and factors that influence the breakdown of fuel contaminants dissolved in ground water. The evaluation of microbial activity and fuel degradation can assist in the selection of appropriate remediation methods following the removal of freephase fuel.

A general description of the water chemistry in the aquifer near the South Ramp is obtained from analysis of the ions and gases dissolved in ground water. Major reactions in the aquifer are deduced from chemical analysis of water and gas from contaminated and uncontaminated parts of the aquifer. A major component of the study is estimating, through increases in the amount of dissolved inorganic carbon (DIC), the amount of respiration that has occurred in contaminated and uncontaminated parts of the aquifer. Compounds such as $\mathrm{O}_{2}, \mathrm{H}_{2} \mathrm{~S}$, and $\mathrm{CH}_{4}$ are diagnostic to specific types of metabolism, and provide insight into microbial respiratory processes in the aquifer. Finally, ratios of specific contaminant compounds in contaminated areas give an independent measure of the extent of petroleum degradation.

\section{Setting}

Diego Garcia is a low carbonate atoll, located in the central Indian Ocean at latitude $7^{\circ} \mathrm{S}$ and longitude $72^{\circ} \mathrm{E}$ (fig. 1). The atoll lagoon is nearly completely enclosed and is open to the ocean only along the northern edge. The climate is tropical, with an average annual temperature of $27^{\circ} \mathrm{C}$ and an average annual humidity of 80 percent. Average annual rainfall from 1951 to 1990 was 106 in., with most rain falling in September to February. Land surface elevation is typically less than $10 \mathrm{ft}$ above mean sea level.

Diego Garcia has been a British territory since the late 18 th century. It was used as a copra plantation, a coaling station, and a military outpost. U.S. Navy activities started in the 1970's. In the early 1980's, a large area (the South Ramp) for parking and fueling airplanes was constructed along the southern half of the airfield. The construction involved filling and grading of coastal wetlands with carbonate sediment dredged from the lagoon. An underground fuel pipeline with many subsurface hydrants was installed. The ramp was capped with packed carbonate sediment and about 18 in. of reinforced concrete. Several asphalt swales collect runoff from the ramp and parts of the taxiway. This runoff is discharged to a pond at the north end of the South Ramp through a covered storm drain. The general layout of the South Ramp is shown in figure 2.

\section{Previous Investigations}

The geohydrology of Diego Garcia was described in a series of unpublished reports prepared for the U.S. Navy (PRC Toups, 1983). More recently, Hunt (1991) showed that changes in the size of the freshwater lens could be related to changes in rainfall over both annual and interannual time scales.

Tribble and others (1994) describe the South Ramp fuel spill and outlined the work in progress for both fuel recovery and aquifer geochemistry. Concentrations of benzene, $\mathrm{CH}_{4}, \mathrm{H}_{2} \mathrm{~S}$, and $\mathrm{CO}_{2}$ at three sites during the January and February 1993 trip were presented. These data indicated the amount of microbial respiration (on the basis of $\mathrm{CO}_{2}$ ) was higher at sites contaminated by fuel than at uncontaminated sites. However, the amount of microbial activity was not quantitatively assessed. 


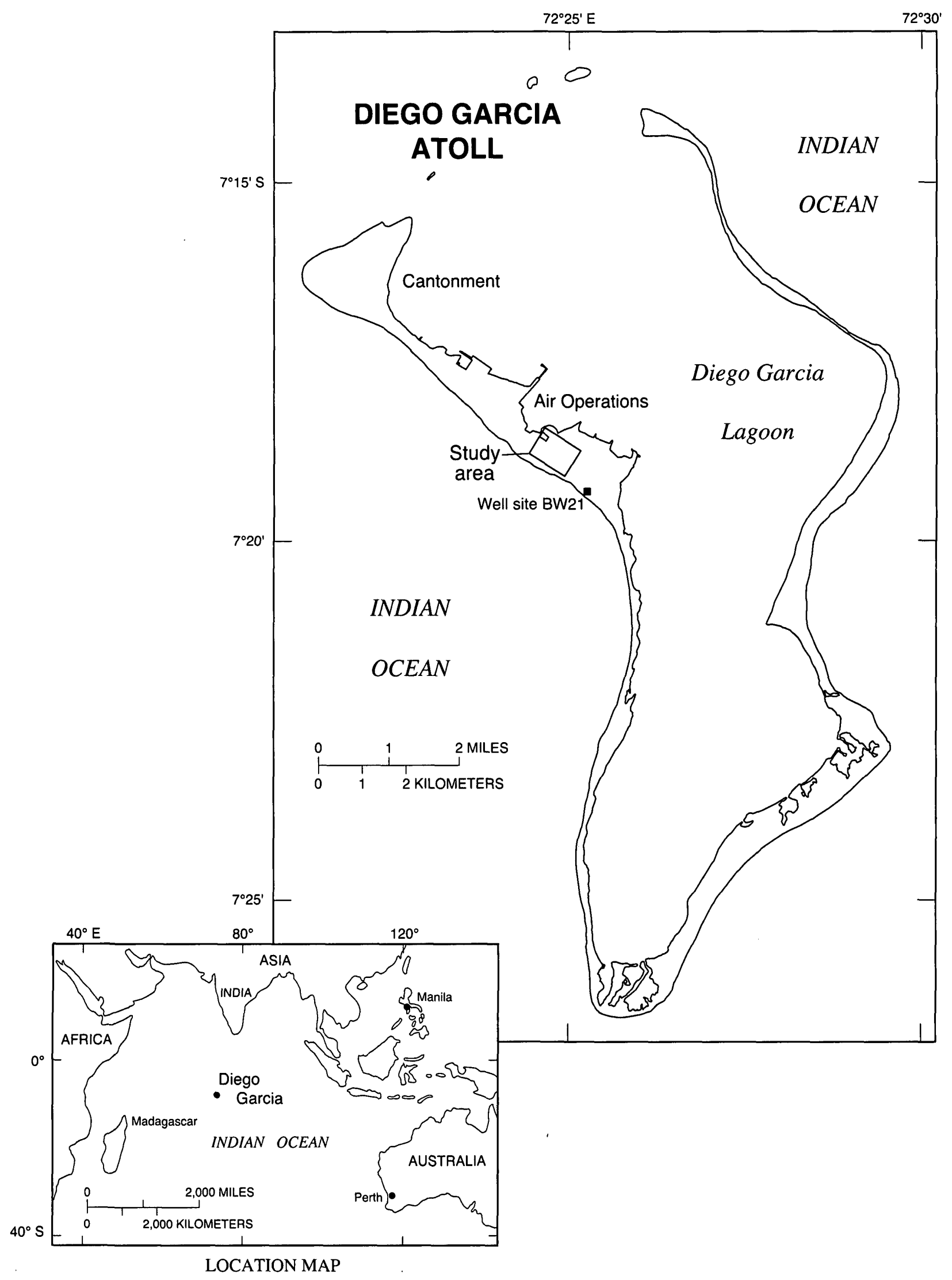

Figure 1. Diego Garcia Atoll in the Indian Ocean and location of the study area. 


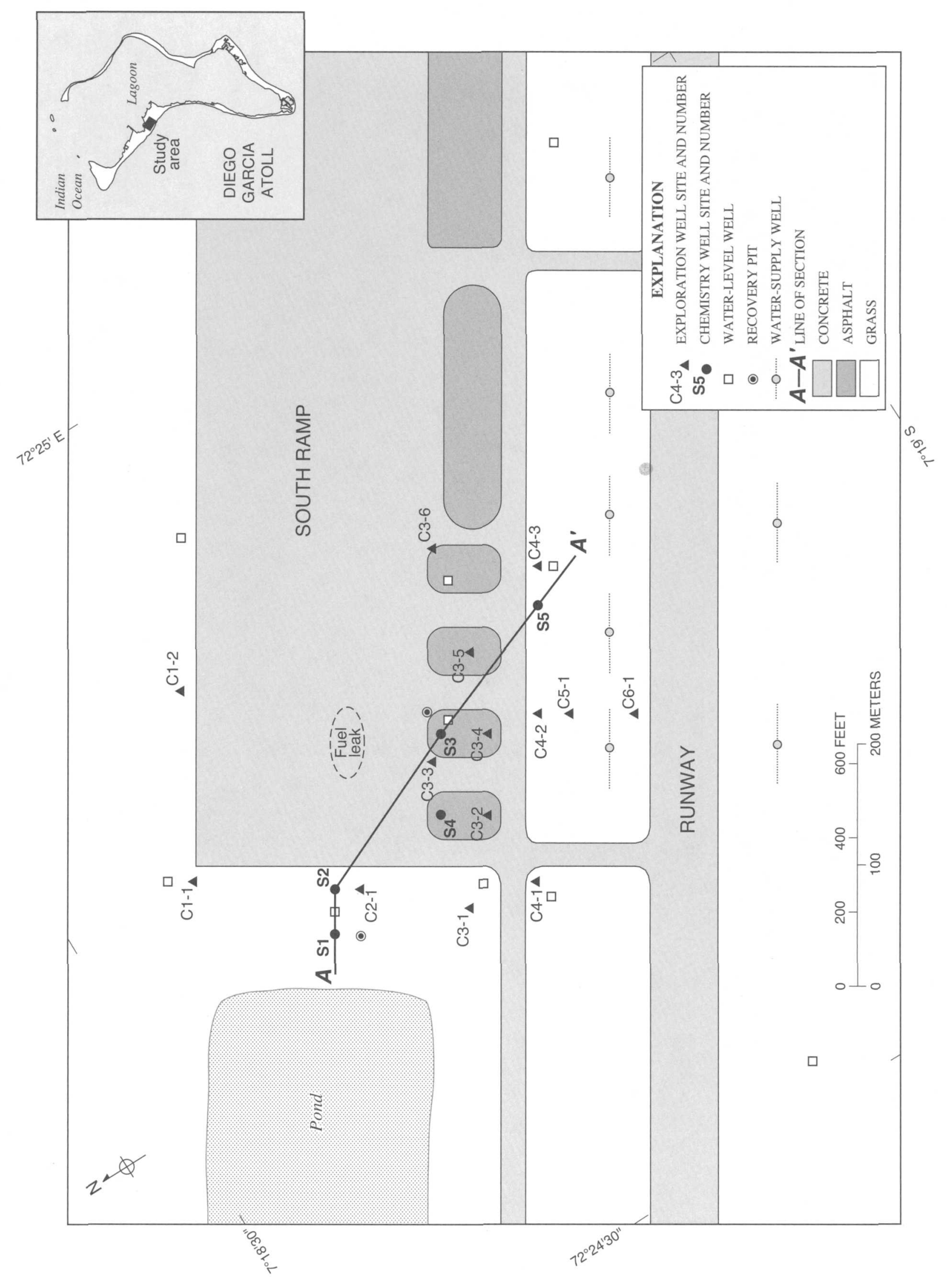

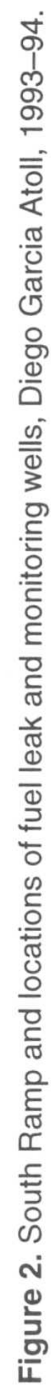




\section{DESCRIPTION OF THE STUDY AREA}

\section{Geology}

Atolls are shoal-water structures that rise from the deep ocean floor and enclose a relatively shallow (less than $300 \mathrm{ft}$ ) lagoon. The base of the atoll is a basaltic volcano that has subsided. The amount of subsidence of the islands of the Chagos Archipelago is unknown. Drilling at the Marshall Islands in the Pacific reached basalt 4,500 ft below mean sea level (Emery and others, 1954). Reef growth during the subsidence of the volcano results in a cap of calcium carbonate minerals that spans the distance from the top of the now-submerged volcanic edifice to the sea surface.

The shallow subsurface geology of atolls is determined by marine precipitation and deposition of carbonate minerals, the chemical alteration (or diagenesis) of these minerals, and changes in sea level. During the most recent ice age $(18,000$ years ago), sea level was at least $300 \mathrm{ft}$ below its current height (Kennett, 1982) and atolls such as Diego Garcia were emergent structures subject to enhanced physical and chemical erosion by waves and rain. The rise in sea level since the last ice age has allowed resumption of reef growth at the top of the atoll and deposition of new carbonate minerals on top of the limestone that was recrystallized during the Pleistocene ice ages. Calcium carbonate from shallowwater reefs is originally precipitated principally as the minerals aragonite and magnesian calcite. But both aragonite and magnesian calcite are more soluble than pure calcite. Over time, diagenetic reactions transform the aragonite and magnesian calcite to a more consolidated and permeable calcitic limestone (Morse and Mackenzie, 1990).

In several well-studied atolls in the Pacific (Vacher and Quinn, 1997), the result is a three-layer structure (from bottom to top) of: (1) dense, well-consolidated Pleistocene limestone; (2) unconsolidated lagoonal sediments of mud, sand, and gravel; and (3) unconsolidated and well-sorted beach sand and gravel. The upper two layers are relatively young, unaltered, and have moderate permeabilities. The lower limestone has a high permeability that formed during the subaerial exposure and recrystallization to calcite (Hamlin and Anthony, 1987). Drilling on Diego Garcia indicated that there was a slight ocean-to-lagoon dip in these layers, and the depth to the unconformity between the Pleistocene limestone and younger sediments appeared to be about $70 \mathrm{ft}$ below mean sea level (PRC Toups, 1983). At other atolls, this depth is typically 20 to $70 \mathrm{ft}$ (Under-wood, 1990).

\section{Hydrology}

Atoll aquifers are recharged by rain infiltrating through a thin unsaturated zone. Recharge from rain typically forms a lens of freshwater that is buoyantly supported by dense saline ground water from the ocean. Mixing between the infiltrated rain and saltwater forms a zone of transitional salinity. The thickness of this transition zone is determined by the rate of recharge, tidal dynamics, and the hydraulic properties of the carbonate aquifer.

According to studies by Hunt (1991) and PRC Toups (1983), the freshwater part of the aquifer at Diego Garcia, as defined by the U.S. Environmental Protection Agency (USEPA) secondary drinking water standard (USEPA, 1989) of $250 \mathrm{mg} / \mathrm{L}$ dissolved $\mathrm{Cl}^{-}$, is composed almost entirely of unconsolidated sand and gravel, with some coral and a few cemented layers of sandstone and conglomerate. The principal freshwater bodies are in the Cantonment and Air Operations areas, where the island is relatively wide. These two areas have provided greater than 99 percent of the supply of freshwater on Diego Garcia. Total ground-water withdrawals average 0.8 to $1.2 \mathrm{Mgal} / \mathrm{d}$.

The aquifer in the Air Operations site is the smaller of the two principal water production areas. Since 1986, about one-third of the water supply for Diego Garcia was pumped from a series of shallow horizontal wells in the Air Operations area. The water table tends to be relatively flat, with a maximum elevation of about $2 \mathrm{ft}$ above mean sea level. The maximum thickness of the freshwater lens is about $65 \mathrm{ft}$. Diurnal oscillations in the water level of the aquifer of several feet are caused by ocean tides propagating through the permeable matrix of the aquifer.

\section{METHODS OF DATA COLLECTION AND ANALYSIS}

The methods used in the collection and analysis of data in this report are given below. This includes a description of the well construction and field sampling methods, field and laboratory techniques for the chemical analysis of water and vapor samples, and numerical 
methods for the analysis of chemical data. Figure 2 shows the Air Operations area, the location of nearby water-supply wells, and the monitoring wells used in this study.

\section{Installation and Sampling of Monitor Wells, Lysimeters, and Vapor Points}

A network of 37 wells was used to collect water chemistry samples from the saturated part of the aquifer. Vapor and water samples from the unsaturated zone were collected using five vapor points and six lysimeters installed at selected sites. The location of the sampling sites (some sites comprise more than one well) is shown in figure 2 . Three types of wells, distinguished by their prefix and method of construction, were constructed and sampled as part of this chemical investigation. Differences in well construction and the type of sample collected required different sampling protocols to be used with each type of well. Water chemistry samples were not collected from wells used to measure water levels.

\section{S-Series Wells}

Twenty S-series wells at five sites (fig. 2) were drilled in October 1992 specifically for collecting water for chemical analysis. The number after the $S$ designates the site. In this report the numeric suffix of a well designates the approximate elevation (in feet below mean sea level) of the screen midpoint. The wells were designed to permit the sampling of water from specific depth intervals below the water table. All wells were drilled using a truck-mounted $31 / 4$-in. inside diameter hollow-stem auger to the target depth. Well casings (2in. inside diameter flush-jointed schedule PVC pipe with a $5 \mathrm{ft}$ screened interval) were assembled inside the auger, a wooden plate at the bottom of the auger was knocked out, and the auger sections were retracted, leaving the casing in the borehole. Water was added during retraction to minimize the upward flow of loose sand inside the auger. Native material was allowed to fill in around the casing as the auger was retracted. Wells were finished at the surface with a cement pad and a locking cap. Wells at sites contaminated by fuel had a temporary surface casing of 10-in. PVC set from the surface to 12 to $13 \mathrm{ft}$ below ground during drilling; this casing prevented the direct contamination of the auger and well casing by free-phase fuel floating on the water table. An additional well (S2-38) apparently cracked near the water table during installation and is contaminated by free-phase fuel. This well was not used to sample dissolved constituents.

The S-series wells were sampled with a batterypowered downhole pump with a packer. The packer was inflated 6 to $8 \mathrm{ft}$ above the bottom of the well and 9 to $12 \mathrm{gal}$ of water were typically purged at a rate of 1 to 2 $\mathrm{gal} / \mathrm{min}$ prior to sampling. After sampling wells contaminated by fuel, the pump was cleaned by pumping about 5 gal of soapy water followed by a 10-gal rinse of potable water. The effectiveness of the decontamination procedure was confirmed by the negative detection of volatile aromatic hydrocarbons at the end of the potable water rinse.

A vapor point also was installed at each $S$ site to permit collection and analysis of gaseous constituents in the unsaturated part of the aquifer. A 1-in. diameter hole was opened to a depth of about $3 \mathrm{ft}$ below land surface using a metal rod and drop hammer. A slotted stainless steel tip with a length of 1/8-in. inside diameter polypropylene tubing was lowered down the hole.

Small glass beads were used as packing around the slotted tip to maintain air flow. A grout seal above the beads was added to secure the tubing and prevent atmospheric vapors from being entrained down the sides of the hole. Vapor points were sampled using a peristaltic pump after purging about $4 \mathrm{~L}$ of vapor through the collection system.

To sample water from the unsaturated zone, lysimeters were installed to depths of 2 and $3 \mathrm{ft}$ below land surface (elevation of 3 to $7 \mathrm{ft}$ above mean sea level) at the three $\mathrm{S}$ sites not overlain by asphalt (S1, S2, and S5). A pilot hole was drilled using the truck-mounted auger. The lysimeter was set into the hole and a slurry of native sand was poured around the ceramic cup. The hole was then backfilled with native material. Water from the lysimeters was collected with a hand pump after being held at vacuum for about 10 days. Yields typically were 400 to $800 \mathrm{~mL}$.

\section{C-Series Wells}

Seventeen C-series wells were drilled in June 1991 following discovery of the leak to permit an areal survey of the contaminant plume. These exploratory wells were constructed of 2-in. inside diameter flush-jointed PVC pipe and installed to a depth of less than $10 \mathrm{ft}$ below the water table. They had a broad screened interval that crossed the water table, and extended above 
land surface at some wells. In this study, 14 of these wells were used to measure volatile aromatic hydrocarbons such as benzene, toluene, ethylbenzene, and xylene concentrations in both the top of the water table and unsaturated parts of the aquifer. Concentrations of $\mathrm{CO}_{2}, \mathrm{O}_{2}$, and $\mathrm{CH}_{4}$ in the unsaturated part of the aquifer also were measured.

Water for the $\mathrm{C}$ wells was collected using a disposable bailer. Prior to collecting water for analysis, the wells were purged by removing at least three well volumes. Water from the bailer was immediately transferred to vials. Wells that had free-floating fuel were not sampled for dissolved constituents. Vapor from the unsaturated part of the aquifer was collected in glass syringes as a battery-powered air blower pulled air from the aquifer through the well screen and up the well bore. About $30 \mathrm{~L}$ of vapor was purged through the collection system prior to sampling.

\section{BW21 Wells}

A site near the south end of the airfield (fig. 1), and far-removed from the fuel leak, was also sampled in this study. The three wells at this site were installed in 1982 as part of a network of monitoring wells throughout both the Cantonment and Air Operations aquifers (PRC Toups, 1983). The wells were constructed of 1.75-in. inside diameter flush-jointed PVC pipe with a screened interval of $5 \mathrm{ft}$. These wells were purged by removing several well volumes of water with a gasoline-powered pump and collecting samples with a battery-powered peristaltic pump.

\section{Field Analysis and Sample Treatment}

At each of the S-series and BW21 wells, ground water was transferred from the pump to a closed cell using gas-impermeable tubing to minimize atmospheric contact during the measurement of $\mathrm{pH}$, dissolved $\mathrm{O}_{2}$, and temperature. The $\mathrm{pH}$ electrode was calibrated against NBS (National Bureau of Standards)-traceable standards $( \pm 0.01)$. Dissolved $\mathrm{O}_{2}$ was determined by use of a polarographic electrode $( \pm 0.2 \mathrm{ppm}, 0.1 \mathrm{ppm}$ detection limit). Temperature ( \pm 0.1$)$ was measured using a thermistor. Samples for the determination of total sulfide $\left(\mathrm{H}_{2} \mathrm{~S}\right)$ were collected, without filtration and minimal atmospheric contact, into 60 -mL glass bottles and immediately fixed with $\mathrm{ZnSO}_{4}$ and $\mathrm{NaOH}$. Samples for measurement of volatile aromatic hydrocarbons in the field lab were collected into two 40-mL glass vials; an additional two vials were collected so that laboratory analysis by gas chromatograph-mass spectrometer (GC-MS) could be done if the field measurement indicated the presence of contaminants.

Samples of water from the unsaturated zone for major-ion and nutrient analysis were collected in disposable 1-gal semirigid polyethylene containers and filtered in a nearby laboratory within 30 minutes of collection. Samples were not filtered at the well head because of the potential contamination introduced by wind and squalls. Water was passed through a 42-mm diameter Watman GF/F filter (nominal pore size 0.7 $\mu \mathrm{m})$ under vacuum filtration. Comparison of samples filtered using GF/C (nominal pore size $1 \mu \mathrm{m}$ ) and ultrafiltration (nominal pore size $3 \mathrm{~nm}$ ) found that ultrafiltered samples were not different in titration alkalinity, $\mathrm{NO}_{3}{ }^{-}+\mathrm{NO}_{2}{ }^{-}$, and $\mathrm{Si}, 1$ percent lower in $\mathrm{NH}_{4}{ }^{+}$, and 3 percent lower in $\mathrm{PO}_{4}{ }^{3+}$. However, ultrafiltration did remove 30 to 70 percent of the organic $C, N$, and $P$; this was attributed to bacteria smaller than $1 \mu \mathrm{m}$ (Hollibaugh and others, 1991). This indicates that the GF/F filters used in this study remove essentially the entire inorganic non-dissolved fraction from a water sample, but that bacterial biomass may be a component of what is reported as dissolved organic carbon, dissolved organic nitrogen, and dissolved organic phosphorus.

Prior to sample filtration, the filtering apparatus was washed with phosphate-free soap and rinsed with demineralized water, followed by two $200-\mathrm{mL}$ aliquots of sample water. Filtered water for determination of titration alkalinity was stored in 175-mL high-density polyethylene bottles and kept chilled; the titration alkalinity samples were filtered to remove small particles of $\mathrm{CaCO}_{3}$ that would otherwise affect the outcome of the alkalinity titration. Filtered water for determination of major ions was stored in $125-\mathrm{mL}$ high-density, $\mathrm{HNO}_{3}$ washed polyethylene bottles, acidified to $\mathrm{pH} 2$ with high-purity $\mathrm{HNO}_{3}$, and kept chilled. Filtered water for determination of nutrients was stored in $\mathrm{HCl}$-washed 125-mL high-density polyethylene bottles. In general, field methods follow procedures described by Tribble and others (1990), Smith and others (1991), and Tribble (1997).

The concentrations of $\mathrm{CO}_{2}, \mathrm{O}_{2}$, and $\mathrm{CH}_{4}$ in the vapor phase of the unsaturated part of the aquifer were measured in the field lab using a portable gas chromatograph with a thermal conductivity detector (GC-TCD). 
The GC-TCD was calibrated against three standard reference gases before and after each field trip. The concentration of volatile aromatic hydrocarbons in water samples from the saturated zone and vapor samples from the unsaturated zone were measured at the field lab using a portable gas chromatograph with a photoionization detector (GC-PID). During the August 1993 and May 1994 trips, wells that tested positive for aromatic hydrocarbons were subject to more complete analysis by GC-MS (see below). The GC-PID was calibrated daily against aromatic hydrocarbon standards and blanks, and had a detection limit of $0.1 \mathrm{ppb}$.

\section{Laboratory Methods}

Analyses for major ions and nutrients were performed at the University of Hawaii Department of Oceanography. This laboratory participates in the USGS standard reference water sample program, and has been approved by the USGS Branch of Quality Assurance. $\mathrm{Ca}^{2+}, \mathrm{Mg}^{2+}, \mathrm{Sr}^{2+}$, and $\mathrm{Na}^{+}$were determined by inductively coupled plasma/ optical emission spectroscopy. $\mathrm{K}^{+}$was determined by atomic absorption spectroscopy. $\mathrm{Cl}^{-}$was determined by titration with $\mathrm{AgNO}_{3} . \mathrm{SO}_{4}{ }^{2-}$ was determined either by ion chromatography or gravimetrically as a $\mathrm{BaSO}_{4}$ precipitate, depending on the sample concentration. Titration alkalinity was determined by multi-point titration with $\mathrm{HCl}$. $\mathrm{H}_{2} \mathrm{~S}$ was determined by potassium iodide titration. $\mathrm{PO}_{4}{ }^{3+}, \mathrm{NO}_{3}{ }^{-}+\mathrm{NO}_{2}{ }^{-}, \mathrm{NH}_{4}{ }^{+}$, and $\mathrm{Si}$ were determined colorimetrically on an autoanalyzer. DOP was calculated as the difference between $\mathrm{PO}_{4}{ }^{3+}$ and total $\mathrm{P}$ following ultraviolet oxidation. DON was calculated as the difference between inorganic and total $\mathrm{N}$ following ultraviolet oxidation. DOC was determined by infrared absorption following ultraviolet oxidation.

The analytical accuracy (agreement between the measured and the calculated or most probable value) of a determination was estimated by comparison with laboratory standards. Standards included both USGS standard reference samples and solutions prepared in the University of Hawaii laboratory. Analytical precision (reproducibility of a measured value) was determined by submission of blind duplicate samples to the laboratory. Values for the precision and accuracy are given in table 1.

Table 1. Analytical precision, accuracy, and detection limits for selected chemical constituents in ground water from Diego Garcia Atoll, 1993-94

[TA, titration alkalinity; DOP, dissolved organic phosphorus; DON, dissolved organic nitrogen; DOC, dissolved organic carbon; >, actual value is greater than value shown; $\mathrm{mg} / \mathrm{L}$, milligrams per liter; meq/L, milliequivalents per liter; $\mu \mathrm{g} / \mathrm{L}$, micrograms per liter;,-- not determined]

\begin{tabular}{|c|c|c|c|c|c|c|}
\hline \multirow[b]{2}{*}{ Constituent } & \multicolumn{2}{|c|}{ Precision $^{2}$} & \multicolumn{2}{|c|}{ Accuracy ${ }^{4}$} & \multirow[b]{2}{*}{$\begin{array}{c}\text { Detection } \\
\text { limit }\end{array}$} & \multirow[b]{2}{*}{ units } \\
\hline & $n^{1}$ & $\begin{array}{c}\text { Average } \\
\text { (percent) }\end{array}$ & $n^{3}$ & $\begin{array}{c}\text { Average } \\
\text { (percent) }\end{array}$ & & \\
\hline $\mathrm{Ca}$ & 13 & 0.60 & 72 & 1.2 & 0.002 & $\mathrm{mg} / \mathrm{L}$ \\
\hline $\mathrm{Mg}$ & 13 & 0.85 & 72 & 0.8 & 0.002 & $\mathrm{mg} / \mathrm{L}$ \\
\hline $\mathrm{Sr}$ & 13 & 1.10 & 72 & 0.6 & 0.002 & $\mathrm{mg} / \mathrm{L}$ \\
\hline $\mathrm{Na}$ & 13 & 0.52 & 56 & 0.2 & 0.1 & $\mathrm{mg} / \mathrm{L}$ \\
\hline $\mathrm{SO}_{4}$ & 13 & 1.02 & 77 & 0.0 & 0.1 & $\mathrm{mg} / \mathrm{L}$ \\
\hline K & 13 & 0.06 & 19 & -1.1 & 0.01 & $\mathrm{mg} / \mathrm{L}$ \\
\hline $\mathrm{Cl}$ & 13 & 1.04 & 103 & -0.6 & 0.2 & $\mathrm{mg} / \mathrm{L}$ \\
\hline $\mathrm{H}_{2} \mathrm{~S}$ & 13 & 0.01 & -- & -- & 0.1 & $\mathrm{mg} / \mathrm{L}$ \\
\hline $\mathrm{TA}$ & 13 & 0.06 & 49 & -0.02 & 0.04 & $\mathrm{meq} / \mathrm{L}$ \\
\hline $\mathrm{PO}_{4}{ }^{3-}$ & 13 & 7.8 & $>50$ & 3 & 0.3 & $\mu \mathrm{g} / \mathrm{L}$ \\
\hline $\mathrm{NO}_{3}^{-}$ & 13 & 64 & $>50$ & 3 & 0.3 & $\mu \mathrm{g} / \mathrm{L}$ \\
\hline $\mathrm{NH}_{4}^{+}$ & 13 & 2.0 & $>50$ & 3 & 0.3 & $\mu \mathrm{g} / \mathrm{L}$ \\
\hline $\mathrm{Si}(\mathrm{OH})_{4}$ & 13 & 0.7 & $>50$ & 3 & 0.006 & $\mathrm{mg} / \mathrm{L}$ \\
\hline DOP & 13 & 33 & $>50$ & 5 & 0.3 & $\mu \mathrm{g} / \mathrm{L}$ \\
\hline DON & 13 & 27 & $>50$ & 5 & 0.3 & $\mu \mathrm{g} / \mathrm{L}$ \\
\hline DOC & 13 & 1.0 & $>50$ & 5 & 0.3 & $\mathrm{mg} / \mathrm{L}$ \\
\hline
\end{tabular}

${ }^{1}$ Number of paired samples

${ }^{2}$ Precision calculated as the average percentage of difference between blind duplicate samples

${ }^{3}$ Number of analyses

${ }^{4}$ Accuracy calculated as the average percentage of difference between a measured value and a primary standard 
Analysis of volatile aromatic compounds by GCMS was done at the Central Laboratory of the USGS. The procedure is similar to USEPA method 524.2. Total petroleum hydrocarbons were analyzed according to USEPA method 418.1; oil and grease were analyzed according to USEPA method 413.2.

\section{Geochemical Calculations}

Calculation of charge balance, saturation state with respect to carbonate minerals, and total dissolved inorganic carbon $\left(\mathrm{DIC}=\mathrm{CO}_{2(\mathrm{aq})}+\mathrm{H}_{2} \mathrm{CO}_{3}+\mathrm{HCO}_{3}{ }^{-}+\right.$ $\mathrm{CO}_{3}{ }^{2-}$ ) were performed using the computer program WATEQ4F (Ball and Nordstrom, 1991). The charge balance, in percent, was used as an overall check of analytical accuracy for the major-ionic constituents, and calculated as:

$$
\text { ChargeBalance }=100 \frac{(\mathrm{Cat}-\mathrm{An})}{\left[\frac{(\mathrm{Cat}+\mathrm{An})}{2}\right]},
$$

where Cat and An are the measured total number of equivalents of cations and anions respectively. A negative charge balance indicates that one or more of the cations was underdetermined, one or more of the anions was overdetermined, or both. Conversely, a positive charge balance indicates that one or more of the cations was overdetermined, one or more of the anions was underdetermined, or both. A charge balance of zero indicates equivalence between the number of cations and anions, as demanded by the law of electrical neutrality, and strongly indicates accuracy in the analytical determinations (Hem, 1989). In practice, a charge balance of less than \pm 5 percent is considered good, and a balance in excess of \pm 10 percent is considered suspect.

The saturation state of a water sample is used to predict if a specific mineral is thermodynamically favored to dissolve or precipitate. For water samples from Diego Garcia, the saturation state with respect to the carbonate mineral aragonite was calculated because it is an abundant mineral in the reefs that build atolls and its solubility constant $\left(\mathrm{K}_{\mathrm{sp}}\right)$ is better defined than that of the magnesian-calcite solid solution series. The degree of saturation is expressed as a saturation index (SI):

$$
S I=\frac{\log I A P}{K_{s p}}
$$

where IAP is the ion activity product of the appropriate ions and $\mathrm{K}_{\mathrm{sp}}$ is the solubility constant for the mineral in question (Drever, 1988; Krauskopf, 1979). An SI of zero occurs when the solution is at equilibrium with the mineral. A positive SI indicates thermodynamic oversaturation and a tendency for the mineral to precipitate. A negative SI indicates thermodynamic undersaturation and a tendency for the mineral to dissolve. Analytic and thermodynamic uncertainty suggest that a range of \pm 0.2 be ascribed to the calculated value of SI for a particular sample.

Bacterial respiration and fuel degradation is evaluated in three ways. First, the concentration of dissolved inorganic carbon (DIC) was used to indicate the total amount of respiration. Because the dissolution of carbonate minerals also releases DIC to the aquifer, it is necessary to remove the contribution of inorganic reactions from the total DIC to calculate the amount of DIC released by bacterial respiration. For each sample, the amount of DIC contributed by the inorganic reaction of carbonate minerals was calculated from the concentrations of $\mathrm{Ca}^{2+}, \mathrm{Mg}^{2+}$, and $\mathrm{Sr}^{2+}$. This amount was then subtracted (on a molar basis) from the total amount of DIC in the sample to calculate the amount of DIC contributed by microbial respiration. DIC from microbial respiration results from both the oxidation of naturally occurring organic matter and the degradation of petroleum hydrocarbons. Comparison of the levels of bacterial respiration between contaminated and uncontaminated areas gives an estimate of the amount of respiration from the microbial oxidation of hydrocarbons.

The amount of microbial respiration resulting from specific metabolic processes was evaluated by comparing the concentrations of either oxidants or by-products specific to the processes. Oxic respiration was evaluated by changes in $\mathrm{O}_{2}$ concentration. Sulfate and nitrate reduction were evaluated by the presence of dissolved sulfide and the depletion of nitrate, respectively. The amount of methane in the unsaturated zone was used to indicate the degree of methanogenesis. This approach does not give a complete accounting of microbial activity, but does indicate the relative contributions of different metabolic processes to total microbial respiration.

The degradation of specific volatile aromatic hydrocarbons was evaluated by calculating the ratio of benzene to more persistent compounds such as trimethyl benzenes, tetramethyl benzenes, and naphthalene (Wilson and others, 1994). 


\section{GEOCHEMISTRY OF GROUND WATER, GASES IN THE UNSATURATED ZONE, AND FUEL HYDROCARBONS}

\section{Chemical Overview}

Field measurements during February 1993, August 1993, and May 1994 of temperature, $\mathrm{pH}$, and dissolved $\mathrm{O}_{2}$ are presented in table 2 (at end of report). Concentrations of dissolved $\mathrm{H}_{2} \mathrm{~S}$ are also shown in table 2 .

Water from the saturated zone was typically warm and exhibited only a narrow range in temperature (27 to $32^{\circ} \mathrm{C}$ ). The average temperature was $29.0^{\circ} \mathrm{C}$. The warm temperatures result from the warmth of rainwater $(25$ to $29^{\circ} \mathrm{C}$ ) in addition to solar warming of ground water. The warmest water was from the shallowest wells at sites S3 and $S 4$, which are in asphalt swales between the cement-covered parking ramp and taxiway. The constantly warm water is conducive to a steady rate of microbial metabolism because lag effects caused by changing temperatures are absent. The warmth of ground water also favors high rates of microbial metabolism (Chapelle, 1993).

Water from the unsaturated zone, collected by lysimeter, had an average temperature of $30.4^{\circ} \mathrm{C}$ and tended to be warmer than water from below the water table. This difference is especially obvious when water temperatures in the unsaturated zone are compared with the average temperature of water below the water table at sites with lysimeters $\left(28.5^{\circ} \mathrm{C}\right)$. Although this may be somewhat a consequence of water from lysimeters heating during the lengthy (typically 10 minutes) sample collection, it also appears that water undergoes more solar heating while in the unsaturated zone than in the saturated zone.

The $\mathrm{pH}$ of ground water from the saturated part of the aquifer was 6.7 to 7.8 , the average $\mathrm{pH}$ was 7.2. Water that had an odor of fuel hydrocarbons (sites S1, $\mathrm{S} 2$, and S3) tended to have the lowest $\mathrm{pH}$ values. There was no large or consistent difference in $\mathrm{pH}$ between water from the saturated zone and water from the unsaturated zone. However, because the unsaturated zone samples were collected by suction lysimeter, it is likely that the loss of $\mathrm{CO}_{2}$ resulted in the measured $\mathrm{pH}$ values being somewhat too high.

Dissolved $\mathrm{O}_{2}$ concentrations in water from wells below the water table were low. Values ranged from 0.9 to greater than $0.1 \mathrm{ppm}$. The average concentration was
$0.2 \mathrm{ppm}$, which is the instrument level of precision and near the detection limit. Because it is possible that trace amounts of atmospheric $\mathrm{O}_{2}$ contaminated the sample during collection, it is reasonable to consider the saturated part of the aquifer as essentially anoxic. Low concentrations of dissolved $\mathrm{O}_{2}$ are common in ground water (White and others, 1990). The concentrations in ground water were significantly different than those measured in rain $(5.6 \mathrm{ppm})$ and seawater $(4.1 \mathrm{ppm})$. The depletion of $\mathrm{O}_{2}$ in ground water results from metabolic consumption by bacteria in the aquifer. Oxygen and $\mathrm{H}_{2} \mathrm{~S}$ concentrations were not measured in water samples from the unsaturated zone because sample water was exposed to the atmosphere during collection.

$\mathrm{H}_{2} \mathrm{~S}$ concentrations in ground water were variable, and ranged from 0.1 to $10.2 \mathrm{ppm} . \mathrm{H}_{2} \mathrm{~S}$ was not detected in any of the rain samples. One seawater sample registered $0.1 \mathrm{ppm} \mathrm{H}_{2} \mathrm{~S}$, which is the level of detection and may be a false positive. Samples that had high concentrations of $\mathrm{H}_{2} \mathrm{~S}$ were from the deepest wells at sites $\mathrm{S} 3$ and S4. These wells tended to be the most saline (see below) and consequently had a larger pool of $\mathrm{SO}_{4}{ }^{2-}$ available for bacterial sulfate reduction.

\section{Concentration of Gases in the Unsaturated Zone}

The concentration of $\mathrm{O}_{2}, \mathrm{CO}_{2}$, and $\mathrm{CH}_{4}$ in the unsaturated zone during the three sampling trips was measured at each the five S-sites using a permanently installed gas point. In the May 1994 trip, additional sampling was done on selected C-wells. Oxygen concentrations were low in all samples, typically about 3 percent (table 3), in contrast with an atmospheric value of about 16 percent. Carbon dioxide and $\mathrm{CH}_{4}$ concentrations were quite variable; $\mathrm{CO}_{2}$ concentrations ranged from 0.1 percent to 13.2 percent (average $=1.9$ percent) and $\mathrm{CH}_{4}$ concentrations ranged from 0 to 55.4 percent (average $=8.1$ percent). This is in sharp contrast to atmospheric values of 0.03 percent for $\mathrm{CO}_{2}$ and $1.6 \mathrm{ppb}$ for $\mathrm{CH}_{4}$. Samples from sites contaminated by fuel hydrocarbons, such as S1, S2, S3, and C2-1 had the highest values of $\mathrm{CO}_{2}$ and $\mathrm{CH}_{4}$ (fig. 3). The lines in figure 3 near the leak are speculative because samples could not be collected from beneath the cement ramp. However, it is clear that sites closest to the leak have the most elevated concentrations of $\mathrm{CO}_{2}$ and $\mathrm{CH}_{4}$ in the unsaturated zone. These values result from the microbial degrada- 
Table 3. Concentration of $\mathrm{O}_{2}, \mathrm{CO}_{2}$, and $\mathrm{CH}_{4}$ in vapor samples from the unsaturated zone, Diego Garcia Atoll [Values in percent]

\begin{tabular}{|c|c|c|c|c|c|}
\hline Well site & Date & Time & $\mathrm{O}_{2}$ & $\mathrm{CO}_{2}$ & $\mathrm{CH}_{4}$ \\
\hline S1 & $1-30-93$ & 1400 & 2.6 & 3.6 & 33.6 \\
\hline S1 & $5-7-94$ & 1600 & 0.2 & 1.2 & 26.1 \\
\hline S2 & $2-2-93$ & 1000 & 3.5 & 3.4 & 24.0 \\
\hline S2 & $8-20-93$ & 1108 & 2.9 & 1.2 & 12.5 \\
\hline S2 & $5-7-94$ & 1600 & 0.3 & 3.0 & 55.4 \\
\hline S3 & $2-1-93$ & 1130 & 2.1 & 13.2 & 0.1 \\
\hline S3 & $8-20-93$ & 1000 & 8.9 & 6.8 & 0.5 \\
\hline S3 & $5-7-94$ & 1600 & 2.2 & 3.1 & 35.2 \\
\hline S4 & $1-30-93$ & 1530 & 13.2 & 0.4 & 2.4 \\
\hline S4 & $8-20-93$ & 928 & 9.4 & 0.4 & 2.6 \\
\hline S4 & $5-7-94$ & 1600 & 2.2 & 0.7 & 5.6 \\
\hline S5 & $2-2-93$ & 1500 & 16.2 & 4.1 & 0 \\
\hline S5 & $8-20-93$ & 1025 & 1.5 & 0.5 & 0.2 \\
\hline S5 & $5-6-94$ & 1655 & 2.9 & 0.1 & 0 \\
\hline $\mathrm{Cl}-1$ & $5-9-94$ & 1540 & 3.4 & 0.7 & 0 \\
\hline $\mathrm{Cl}-2$ & $5-9-94$ & 1708 & 3.5 & 0.2 & 0 \\
\hline C2-1 & $5-12-94$ & 1327 & 3.4 & 2.3 & 11.7 \\
\hline C3-1 & $5-12-94$ & 1230 & 3.3 & 0.3 & 0 \\
\hline C $3-3$ & $5-12-94$ & 1320 & 3.3 & 0.1 & 0 \\
\hline C3-4 & $5-9-94$ & 1725 & 3.1 & 1.3 & 1.4 \\
\hline C3-5 & $5-9-94$ & 1718 & 3.4 & 0.2 & 0 \\
\hline C3-6 & $5-9-94$ & 1536 & 3.3 & 0.1 & 0 \\
\hline C4-1 & $5-9-94$ & 1528 & 3.0 & 2.3 & 0 \\
\hline C4-3 & $5-9-94$ & 1420 & 3.4 & 0.1 & 0 \\
\hline C5-1 & $5-9-94$ & 1412 & 3.5 & 0.1 & 0 \\
\hline C6-1 & $5-9-94$ & 1400 & 3.4 & 0.1 & 0 \\
\hline
\end{tabular}




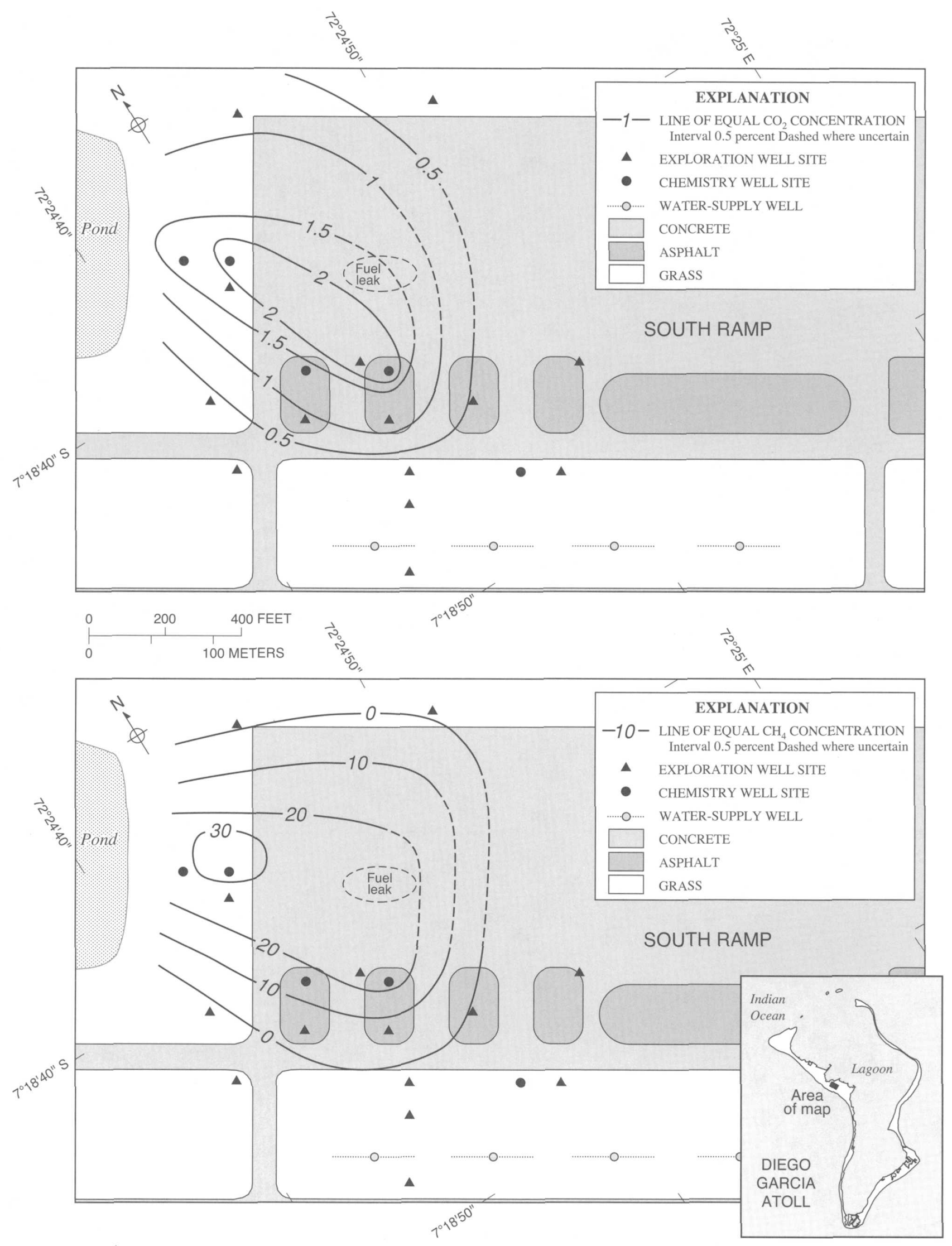

Figure 3. Carbon dioxide $\left(\mathrm{CO}_{2}\right)$ and methane $\left(\mathrm{CH}_{4}\right)$ concentrations in the unsaturated zone of the aquifer near the South Ramp in May 1994, as a percentage of total gas concentration, Diego Garcia Atoll, $1993-94$. 
tion of fuel in the unsaturated zone and near the top of the water table.

The water table in the Air Operations area is quite shallow (typically less than $6 \mathrm{ft}$ below ground surface) and aquifer water levels exhibit diurnal tidal changes of 3 to $4 \mathrm{ft}$ (this is about 60 to 80 percent of the tide range in the ocean). Consequently, about half of the volume of gas in the unsaturated zone is displaced or compressed with every tide cycle. Thus, it is likely that the concentrations of gases in the unsaturated zone are highly variable and follow a tidal pattern. Preliminary data (R.W. Lee, USGS, written commun., 1995) shows 5- to 8-fold tidal fluctuations in the concentrations of $\mathrm{O}_{2}, \mathrm{CO}_{2}$, and $\mathrm{CH}_{4}$. The dynamic physical processes in the unsaturated zone may explain much of the variability seen at a given site over time.

\section{Major-Dissolved lons}

For the purposes of this report, the major-dissolved ions are considered to include the cations $\mathrm{Ca}^{2+}, \mathrm{Mg}^{2+}$, $\mathrm{Sr}^{2+}, \mathrm{Na}^{+}$, and $\mathrm{K}^{+}$and the anions $\mathrm{Cl}^{-}, \mathrm{SO}_{4}{ }^{2-}$, and $\mathrm{HCO}_{3}{ }^{-}$ . Previous work at other atolls (for example, Kwajalein Atoll, Tribble, 1997) has shown that as recharge water from rain mixes with deep saline water from the ocean, the ions $\mathrm{Cl}^{-}, \mathrm{Na}^{+}$, and $\mathrm{K}^{+}$undergo little if any chemical reaction and mix conservatively. In contrast, $\mathrm{Ca}^{+2}$, $\mathrm{Mg}^{+2}, \mathrm{Sr}^{+2}$ and $\mathrm{HCO}_{3}{ }^{-}$showed a significant excess over what would be expected from conservative mixing. This excess was attributed to both the dissolution of carbonate minerals and, for DIC, oxidation of organic matter.

Ground-water samples from Diego Garcia had low $\mathrm{Cl}^{-}$concentrations (table 4, at end of report). The highest value measured (site $S 3$ at a depth of $40 \mathrm{ft}$ below mean sea level) was $54.6 \mathrm{mg} / \mathrm{L}$, or less than 0.3 percent the concentration of seawater. The two rain samples had $\mathrm{Cl}^{-}$concentrations of $0.1 \mathrm{mg} / \mathrm{L}$. However, the average $\mathrm{Cl}^{-}$concentration of water from the unsaturated zone collected by lysimeters was $8.6 \mathrm{mg} / \mathrm{L}(\mathrm{n}=13)$, suggesting that the salinity of water recharging the aquifer is higher than the two rain samples collected. Two reasons for this are the loss of water (but not salt) from evapotranspiration and the dry deposition of marine aerosols.

The concentrations of $\mathrm{Na}^{+}, \mathrm{K}^{+}$, and $\mathrm{SO}_{4}{ }^{2-}$ were also low in the ground-water samples. When the concentrations of these ions are plotted against dissolved $\mathrm{Cl}^{-}$concentrations, there is broad scatter around the lines for conservative mixing between rain and seawater (fig. 4). This scatter is somewhat greater than would be expected from analytical uncertainty alone. $\mathrm{SO}_{4}{ }^{2-}$ showed the greatest deviation from conservative mixing, with both excesses and deficiencies. Several wells also appeared to have excesses of $\mathrm{K}^{+}$. $\mathrm{Na}^{+}$shows the closest correspondence to the conservative mixing line, but also exhibited some departures. The departures in these elements is probably a result of biological activity (especially with respect to $\mathrm{SO}_{4}{ }^{2-}$, which is removed by dissimilatory sulfate reduction and added by the subsequent oxidation of the resulting sulfide) and the dry deposition of marine aerosols having ion ratios different from seawater (Andrae and others, 1986; Mouri and Okada, 1993).

The bivalent cations $\mathrm{Ca}^{2+}, \mathrm{Mg}^{2+}$, and $\mathrm{Sr}^{2+}$ showed extreme enrichments over what would be expected from conservative mixing between rain and seawater (fig. 5). These excesses are a result of the dissolution of the carbonate minerals aragonite and magnesium-calcite. The ratio of the excess cations (on a molar basis) indicates the net dissolution of a carbonate mineral having the composition $\mathrm{Ca}_{0.47} \mathrm{Mg}_{0.52} \mathrm{Sr}_{0.01} \mathrm{CO}_{3}$. Although this composition is close to that of the mineral dolomite, the geochemical setting of Diego Garcia suggests that the presence of dolomite is unlikely because dolomite is a very rare mineral in modern reef and atoll sediments (Morse and Mackenzie, 1990). More likely, the observed excesses result from the dissolution of high$\mathrm{Mg}$ calcites and partial reprecipitation as a less soluble calcite with a lower $\mathrm{Mg}$ content. The 1 percent enrichment in $\mathrm{Sr}$ also indicates the dissolution of aragonite, which typically has a Sr content of less than 1 percent (Morse and Mackenzie, 1990).

\section{Nutrients and Organic Carbon}

Ground-water (saturated and unsaturated) nutrient concentrations tended to be elevated over both rain and seawater (table 5 , at end of report). $\mathrm{PO}_{4}{ }^{3+}$ concentrations in ground water averaged $16.6 \mu \mathrm{g} / \mathrm{L}$, in contrast with rain and seawater concentrations of 2.8 and 6.7 $\mu \mathrm{g} / \mathrm{L}$ respectively. $\mathrm{NO}_{3}{ }^{-}$concentrations in ground water averaged $20.3 \mu \mathrm{g} / \mathrm{L}$, in contrast with rain and seawater concentrations of 14.5 and $5.1 \mu \mathrm{g} / \mathrm{L}$ respectively. $\mathrm{NH}_{4}{ }^{+}$concentrations in ground water averaged 796 $\mu \mathrm{g} / \mathrm{L}$, in contrast with rain and seawater concentrations of 9 and $16 \mu \mathrm{g} / \mathrm{L}$ respectively. Samples from the unsaturated zone had much more of the inorganic $\mathrm{N}$ as 


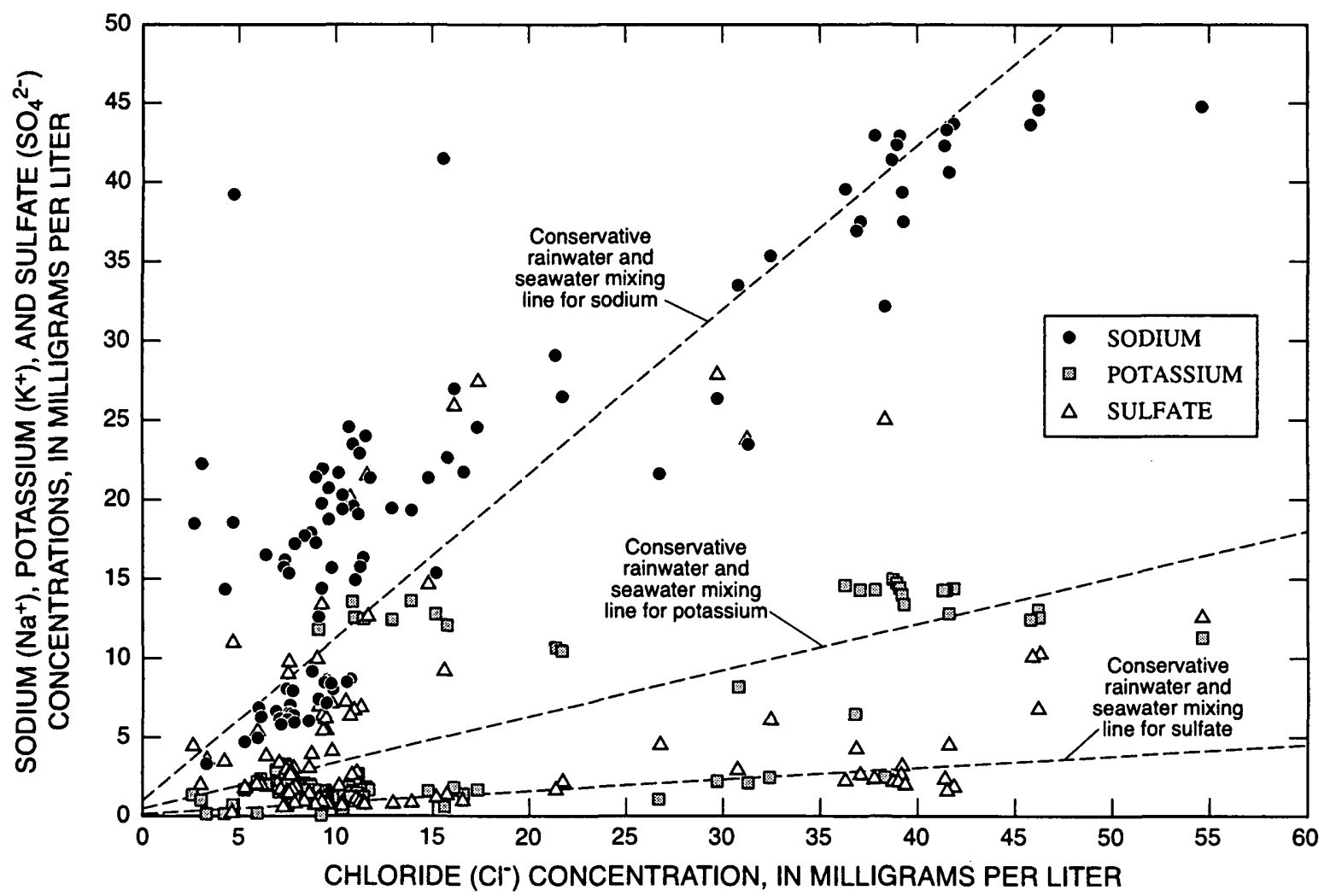

Figure 4. Concentrations of dissolved sodium $\left(\mathrm{Na}^{+}\right)$, dissolved potassium $\left(\mathrm{K}^{+}\right)$, and dissolved sulfate $\left(\mathrm{SO}_{4}{ }^{2-}\right)$ compared with dissolved chloride $\left(\mathrm{CL}^{-}\right)$in ground-water samples from S-series wells and lysimeters in February 1993, August 1993, and May 1994, Diego Garcia Atoll.

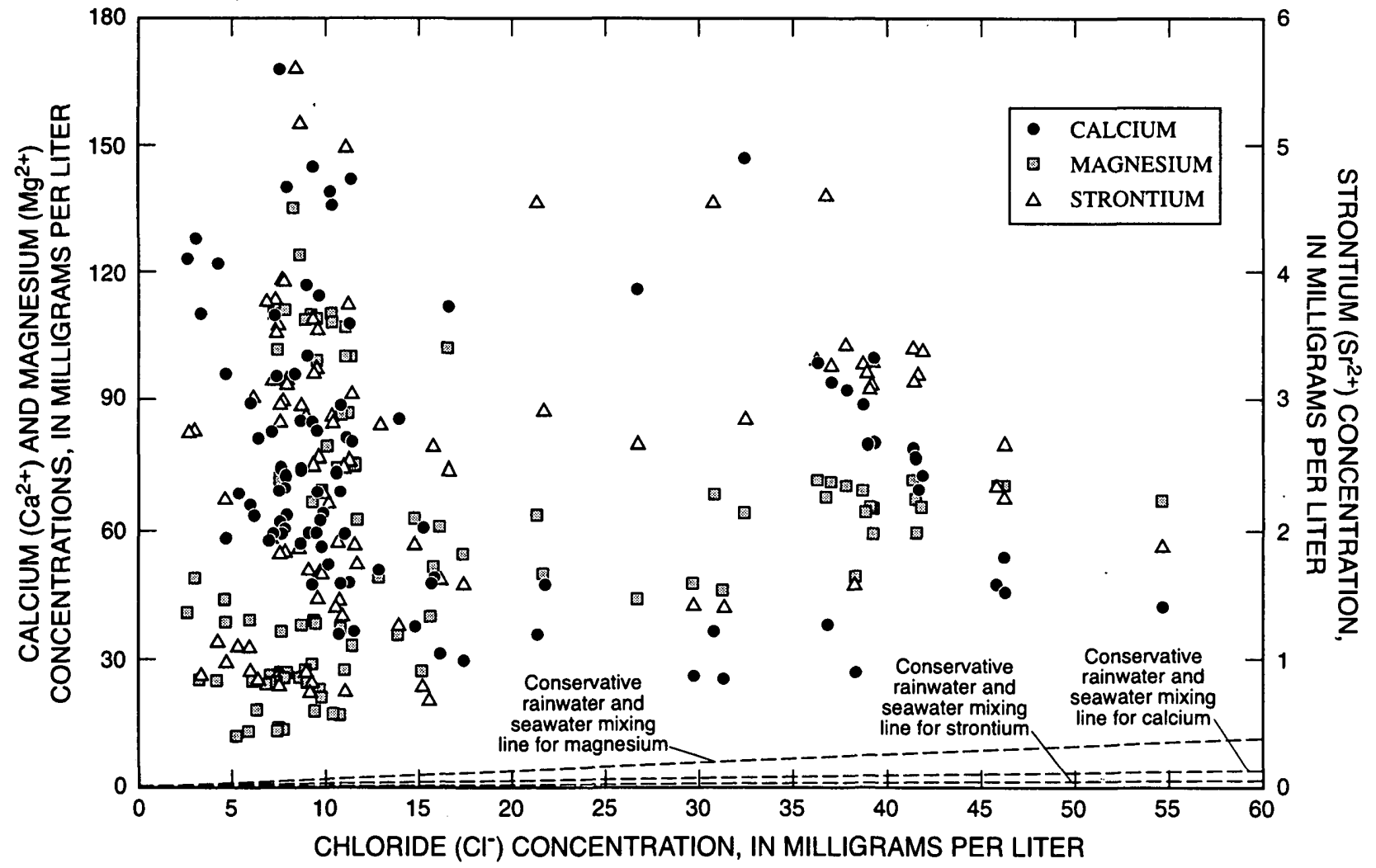

Figure 5. Concentrations of dissolved calcium $\left(\mathrm{Ca}^{2+}\right)$, dissolved magnesium $\left(\mathrm{Mg}^{2+}\right)$, and dissolved strontium $\left(\mathrm{Sr}^{2+}\right)$ compared with dissolved chloride $(\mathrm{Cl})$ in ground-water samples from $\mathrm{S}$-series wells and lysimeters in February 1993, August 1993, and May 1994, Diego Garcia Atoll. 
$\mathrm{NO}_{3}{ }^{-}$compared with $\mathrm{NH}_{4}{ }^{+}$(average 30 percent $\mathrm{NO}_{3}{ }^{-}$) than samples from below the water table (average 2 percent $\mathrm{NO}_{3}{ }^{-}$). This is a result of the reducing conditions below the water table and loss of $\mathrm{NO}_{3}{ }^{-}$to denitrification. The average concentration of dissolved $\mathrm{Si}$ in ground-water samples was $1,098 \mu \mathrm{g} / \mathrm{L}$. This is much higher than the concentrations measured in rain $(6$ $\mu \mathrm{g} / \mathrm{L}$ ) and seawater (average $=87 \mu \mathrm{g} / \mathrm{L}$ ). Dissolved $\mathrm{Si}$ is considered a nutrient because the absence of Si-containing minerals means that the chemistry of dissolved $\mathrm{Si}$ is controlled by biologic, rather than geologic, reactions. The elevated concentrations of dissolved inorganic $\mathrm{N}$, $\mathrm{P}$, and $\mathrm{Si}$ are consistent with the microbial oxidation of organic matter and the concomitant release of nutrients.

A plot of dissolved $\mathrm{PO}_{4}{ }^{3+}$ as a function of dissolved inorganic $\mathrm{N}\left(\mathrm{NO}_{3}{ }^{-}+\mathrm{NH}_{4}{ }^{+}\right.$, fig. 6) shows no relation between the release of $\mathrm{N}$ and $\mathrm{P}$ in the organic matter undergoing oxidation in the ground-water samples. Similarly, dissolved $\mathrm{Si}$ as a function of dissolved inorganic $\mathrm{N}$ (fig. 6) also shows little relation between the release of $\mathrm{N}$ and $\mathrm{Si}$ from the oxidation of organic matter. Possible reasons for this are multiple sources of organic matter with different $\mathrm{N}: \mathrm{P}$ ratios, removal of $\mathrm{P}$ by sorbtion onto carbonate minerals, and removal of $\mathrm{N}$ by denitrification.

Concentrations of organic $\mathrm{C}, \mathrm{N}$, and $\mathrm{P}$ in ground water were variable and reflected the bulk composition of natural dissolved organic material and dissolved fuel constituents. Dissolved organic carbon (DOC) concentrations averaged $5.2 \mathrm{mg} / \mathrm{L}$ and ranged from 1.2 to 17.6 $\mathrm{mg} / \mathrm{L}$. DOC concentrations in ground water were much higher than the concentrations measured in either rain (average $0.8 \mathrm{mg} / \mathrm{L}$ ) or seawater (average $0.4 \mathrm{mg} / \mathrm{L}$ ). Dissolved organic phosphorus (DOP) concentrations averaged $5.3 \mu \mathrm{g} / \mathrm{L}$ and ranged from 0 to $13.6 \mu \mathrm{g} / \mathrm{L}$. Ground-water concentrations of DOP were close to those measured in rain (average $=4.3 \mu \mathrm{g} / \mathrm{L}$ ) and seawater (average $=6.0 \mu \mathrm{g} / \mathrm{L})$. Dissolved organic nitrogen $(\mathrm{DON})$ concentrations averaged $197 \mu \mathrm{g} / \mathrm{L}$ and ranged from 45 to $621 \mu \mathrm{g} / \mathrm{L}$. DON concentrations in ground water were, on average, about twice the concentrations measured in both rain $(\mathrm{DON}=95 \mu \mathrm{g} / \mathrm{L})$ and seawater $(106 \mu \mathrm{g} / \mathrm{L})$.

Within a water sample, there was no consistent relation between the concentrations of DOC, DON, and DOP (fig. 7). The ratios of organic $\mathrm{C}, \mathrm{N}$, and $\mathrm{P}$ were extremely variable, ranging from 110 to 44,800 (average $=2,160$ ) for DOC:DOP and 3.9 to 97 (average=30) for DOC:DON. When the organic C:N and C:P ratios are plotted against the DOC concentration, there is a trend towards organic matter with lower $\mathrm{N}$ and $\mathrm{P}$ ratios in samples having high DOC concentrations (fig. 8). Thus, ground-water samples having elevated DOC concentrations do not show a concomitant increase in DOP or DON. Hydrocarbon contamination was evident in samples with high concentrations of DOC (see below). The low $\mathrm{N}$ and $\mathrm{P}$ organic content of hydrocarbons tends to raise the organic $\mathrm{C}: \mathrm{N}$ and $\mathrm{C}: \mathrm{P}$ ratios in water with high levels of DOC.

\section{Assessment of Fuel Contamination in the Aquifer}

Because high priority was given to immediate remediation and recovery of free-phase fuel while maintaining the operational status of the South Ramp, a formal site characterization was not done. Following the initial characterization of June 1991 (C.D. Hunt, Jr., USGS, written commun., 1991), the chemical work done during this study was designed to provide an overview of geochemical process in both contaminated and uncontaminated parts of the aquifer. The goal of this work was to determine the amount of bacterial activity in both uncontaminated and hydrocarbon-affected areas so that post-fuel recovery remedial methods could be selected. Sampling for contaminant hydrocarbons was not designed to show the spatial distribution of all fuel constituents in the aquifer. However, the data does permit a generalized characterization of the plume. Hydrocarbons were found dissolved in ground water, as a vapor phase in the unsaturated zone, and floating as a free-phase layer on top of the water table.

Following discovery of the leak in May 1991, a reconnaissance trip was performed by USGS personnel (C.D. Hunt, Jr., USGS, written commun., 1991). During this trip, $17 \mathrm{C}$-wells were installed to map the areal distribution of free-phase fuel. On the three subsequent trips that form the basis for this report (February 1993, August 1993, and May 1994) 14 remaining C-wells (three were destroyed during repair of the fuel line and groundskeeping activities), two fuel recovery pits, and well S2-50 (casing cracked) were examined for freephase fuel.

Fuel thickness in a well is not a direct measure of the thickness of the fuel layer in the surrounding aquifer. Typically, the fuel column in a well is several times larger than the actual thickness in the surrounding aqui- 


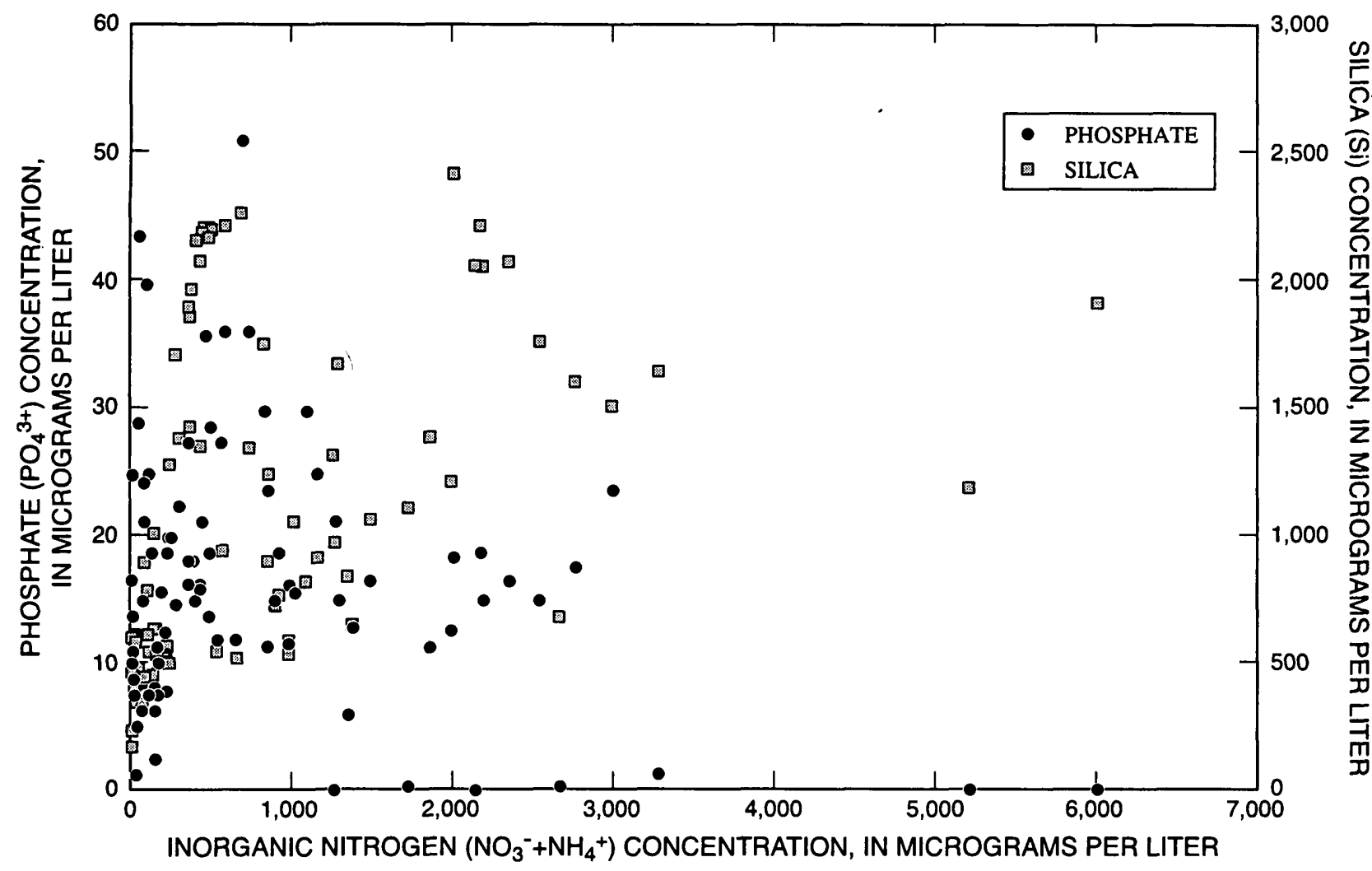

Figure 6. Concentrations of dissolved phosphate $\left(\mathrm{PO}_{4}{ }^{3+}\right)$ and dissolved silica (Si) compared with total dissolved inorganic nitrogen $\left(\mathrm{NO}_{3}{ }^{-}+\mathrm{NH}_{4}{ }^{+}\right)$in ground-water samples from S-series wells and lysimeters in February 1993 , August 1993, and May 1994, Diego Garcia Atoll.

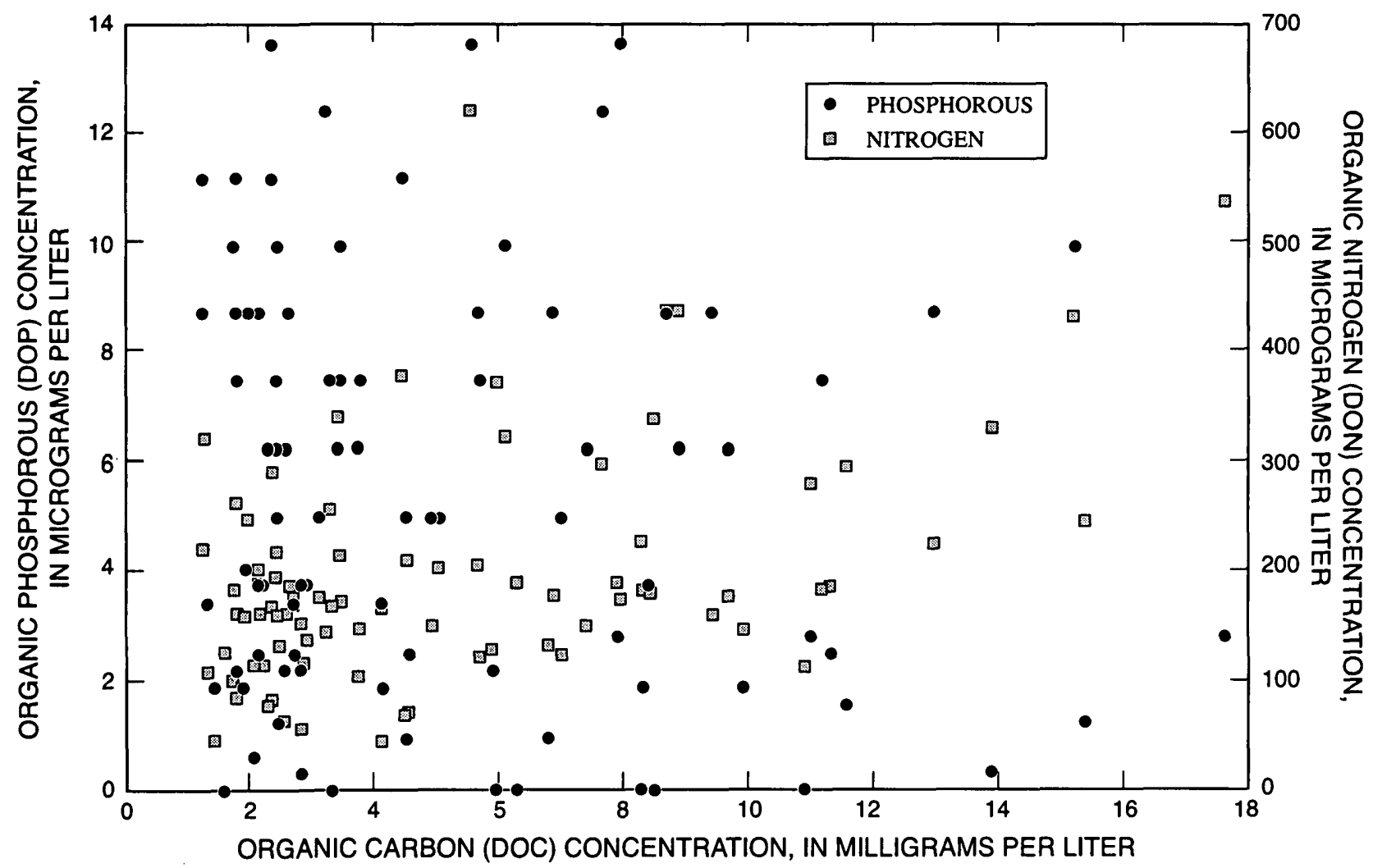

Figure 7. Concentrations of dissolved organic phosphorous (DOP) and dissolved organic nitrogen (DON) compared with dissolved organic carbon (DOC) in ground-water samples from S-series wells and lysimeters in February 1993, August 1993, and May 1994, Diego Garcia Atoll. 


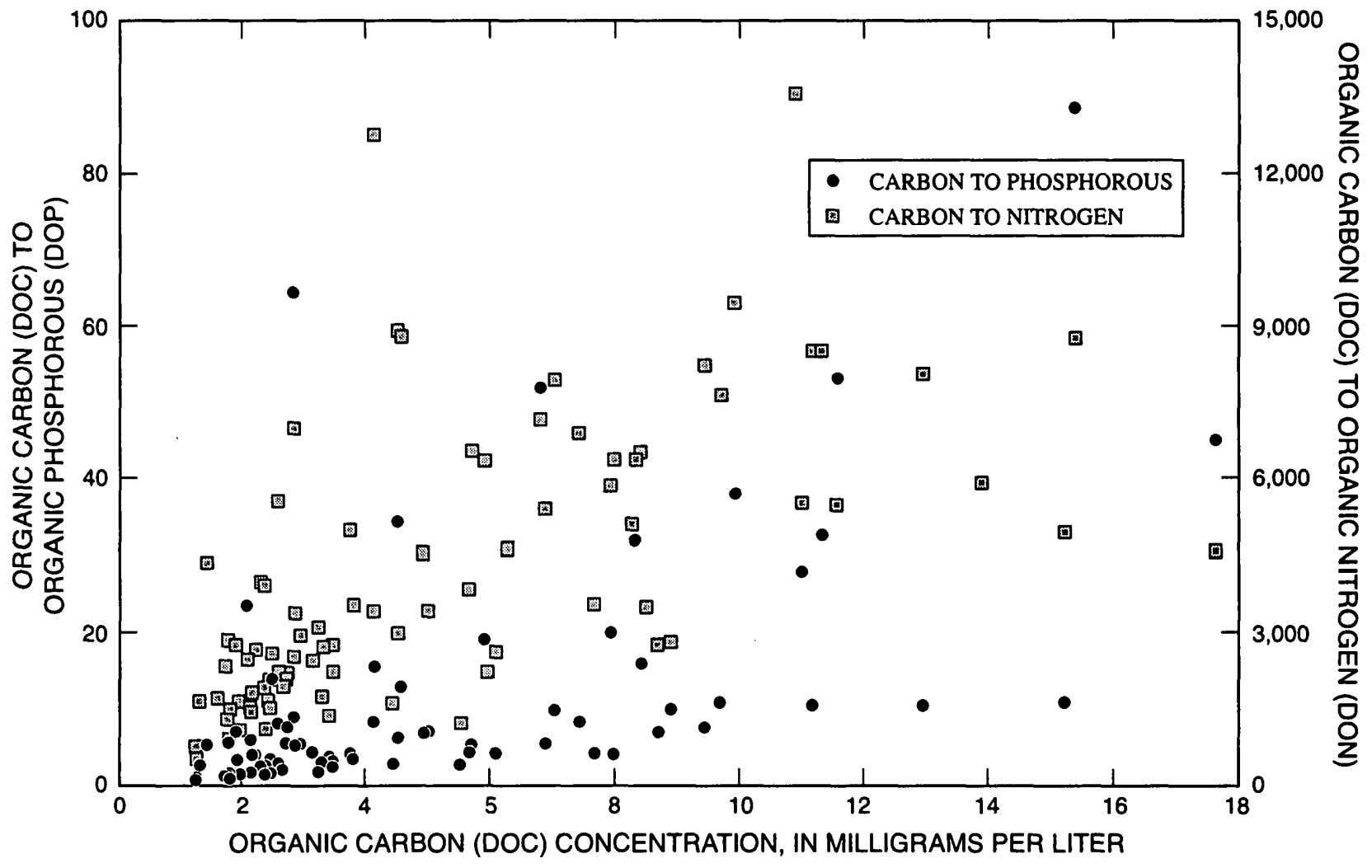

Figure 8. Relation between dissolved organic carbon (DOC) to dissolved organic phosphorous (DOP) and dissolved organic carbon (DOC) to dissolved organic nitrogen (DON) compared with dissolved organic carbon (DOC) in ground-water samples from S-series wells and lysimeters in February 1993, August 1993, and May 1994, Diego Garcia Atoll. 
fer (Ballestero and others, 1994; Huntley and others, 1994) because of differences in specific gravity, physical properties of the aquifer, temporal changes in pressure, and flow dynamics of both the fuel and water capillary fringes. At Diego Garcia, this is compounded by the large tidal oscillations in the water table. Fuelrecovery operators report that fuel thickness in the recovery pits varies with tidal stage, and is thickest at high tide. Consequently, measurements of free-fuel thickness do not give an accurate representation of thickness in the aquifer. However, the limited data available (table 6) suggest that substantial fuel remains in the aquifer as a free-phase layer on the water table, despite the recovery of $134,000 \mathrm{gal}$ of fuel from the recovery pits between May 1991 and April 1994 (BJS International Associates, Diego Garcia, written commun., 1994). However, since the initial characterization in June 1991, free-phase fuel has not been observed in wells that were initially sited outside the free-phase plume, suggesting that the free-phase portion of the plume does not appear to have spread over an extensive area during the period of observation.

\section{Hydrocarbons in Ground Water and Soil Vapor}

The extent of hydrocarbon contamination was assessed through (1) field measurements of volatile organic carbon (VOC) compounds in water and soil vapor using a GC-PID, (2) laboratory measurements of total petroleum hydrocarbons (TPH) and oil and grease in ground water, (3) laboratory measurements of dissolved organic carbon (DOC), and (4) laboratory GCMS scans of VOC compounds in ground water. Special attention was paid to determination of VOC because several aromatic compounds, such as benzene, are both highly soluble (relative to aliphatic hydrocarbons) and toxic. The GC-MS scans were not initially part of the sampling protocol, but were started after the February 1993 sampling trip. The laboratory GC-MS more accurately measures VOC compounds than the GC-PID used in the field, and by characterizing the entire VOC inventory, can be used to infer microbial activity and preferential degradation of selected compounds.

The analysis of TPH and oil and grease was discontinued after the February 1993 trip because the detection levels were high relative to the observed concentrations. Of 11 wells that pumped obviously contaminated water (as indicated by a strong fuel odor and subsequent detection of volatile aromatic compounds), the TPH value was above the detection limit at only three well sites (table 7). The oil and grease analysis confirmed contamination in 10 of the 11 wells, but at a low precision and gave what appeared to be a false positive for a well about $1 \mathrm{mi}$ from the site of the leak that exhibited no other signs of contamination. Also, the DOC measurements provide a reasonable proxy for the presence of hydrocarbons. Figure 9 shows the relation between DOC and field GC measurements of benzene. Typically, wells with DOC concentrations less than 3 ppm were uncontaminated by hydrocarbons, whereas nearly all samples with DOC concentrations greater than $4 \mathrm{ppm}$ had detectable levels of benzene.

High concentrations of DOC are not a reasonable predictor of benzene concentrations; however, samples from a given site tend to have similar DOC:benzene ratios. For example, S3 had high levels of DOC while maintaining relatively low benzene concentrations whereas sites S1 and S2 tended to have higher benzene and lower DOC concentrations. If the elevated DOC concentrations result from petroleum hydrocarbons, differences between sites may be a result of plume maturation and different amounts of aliphatic compared with aromatic hydrocarbons in ground water. Because benzene was found in all wells having a fuel odor, the combination of detectable benzene and elevated DOC concentrations is taken as a reliable indicator of fuel contamination.

Benzene concentrations in ground water and in soil vapor steadily increased during the course of the three sampling trips. Hydrologic sections of benzene concentrations measured with the GC-PID in the field at sites S1, S2, S3, and S5 are shown in figure 10. From February 1993 to May 1994, maximum measured concentrations in water have increased from about 10 to $30 \mathrm{ppb}$. Because the hydrologic section does not show the center of the plume nor is it aligned along a flow path, it is unclear if the increase is a result of advective flow of more contaminated water moving from the center of the plume past the wells, or if the increase is a result of continued partitioning from the free-phase fuel layer in ground water.

Despite the increasing concentration of contaminants within the defined plume, the extent of dissolved aromatic hydrocarbons does not appear to have spread substantially since the first sampling in February 1993. Table 8 shows the concentrations of benzene in ground water and soil vapor measured during the three trips. 
Table 6. Approximate thickness of free-phase fuel at South Ramp wells and recovery pits, Diego Garcia Atoll [--, not measured; D, destroyed during pipeline repair; >, actual values is greater than value shown; $\sim$, approximately]

\begin{tabular}{|c|c|c|c|c|}
\hline \multirow[b]{2}{*}{ Well site } & \multicolumn{4}{|c|}{$\begin{array}{c}\text { Fuel thickness } \\
\text { (feet) }\end{array}$} \\
\hline & June $1991^{1}$ & February $1993^{2}$ & August $1993^{3}$ & May $1994^{3}$ \\
\hline C2-1 & 1.8 & -2 & 1.91 & 1.78 \\
\hline $\mathrm{C} 2-2$ & 0.9 & D & D & D \\
\hline $\mathrm{C} 2-3$ & 0.02 & D & D & D \\
\hline S2-37 & not installed & $>3$ & 3.94 & 4.74 \\
\hline S3 recovery pit & 1.5 & -- & 0.95 & 0.67 \\
\hline S1 recovery pit & not installed & -- & 0.69 & 0.27 \\
\hline
\end{tabular}

1 Measurements made using fuel paste on a tape measure

2 Measurements made using a bailer lowered into the well

3 Measurements made using a Keck free-product interface probe

Table 7. Concentrations in ground water of benzene, dissolved organic carbon, oil and grease, and total petroleum hydrocarbons, February 1993, Diego Garcia Atoll

[All quantities in milligrams per liter except benzene in ppb; $\mathrm{ft}$, feet; ppb, parts per billion; ppm, parts per million; nd, no detection; $<$, actual value is less than value shown]

\begin{tabular}{|c|c|c|c|c|c|}
\hline Well site & $\begin{array}{l}\text { Altitude } \\
\text { (ft) }\end{array}$ & $\begin{array}{l}\text { Benzene } \\
\text { (ppb) }\end{array}$ & $\begin{array}{l}\text { Dissolved organic } \\
\text { carbon } \\
\text { (ppm) }\end{array}$ & $\begin{array}{l}\text { Oil and grease } \\
\text { (ppm) }\end{array}$ & $\begin{array}{l}\text { Total petroleum } \\
\text { hydrocarbons } \\
\text { (ppm) }\end{array}$ \\
\hline S1 & -9 & 7.2 & 13.9 & 3 & $<0.7$ \\
\hline S1 & -20 & 7.5 & 6.8 & 3 & 1 \\
\hline S1 & -31 & 6.3 & 5.9 & 3 & $<.7$ \\
\hline S1 & -39 & 5.7 & 4.1 & 2 & $<.7$ \\
\hline S2 & -9 & 11.5 & 10.9 & 2 & $<.7$ \\
\hline S2 & -19 & 4.9 & 8.3 & 2.5 & $<.7$ \\
\hline S2 & -29 & 10.2 & 11.6 & 2 & $<.7$ \\
\hline S3 & -11 & 0.8 & 17.6 & 5 & $<.7$ \\
\hline S3 & -21 & 1.9 & 11.0 & 2 & $<.7$ \\
\hline S3 & -30 & 2.0 & 9.9 & 3 & 1.5 \\
\hline S3 & -40 & 1.6 & 4.6 & $<1.3$ & 1 \\
\hline S4 & -11 & nd & 4.1 & $<1.3$ & $<.7$ \\
\hline S4 & -21 & nd & 4.5 & $<1.3$ & $<.7$ \\
\hline S4 & -31 & nd & 2.8 & $<1.3$ & $<.7$ \\
\hline S4 & -41 & nd & 2.5 & $<1.3$ & $<.7$ \\
\hline S5 & -11 & nd & 3.3 & $<1.3$ & $<.7$ \\
\hline S5 & -18 & nd & 2.8 & $<1.3$ & $<.7$ \\
\hline S5 & -27 & nd & 2.1 & $<1.3$ & $<.7$ \\
\hline S5 & -37 & nd & 1.9 & $<1.3$ & $<.7$ \\
\hline S5 & -46 & nd & 1.8 & $<1.3$ & $<.7$ \\
\hline BW21 & -8 & nd & 2.1 & 2 & $<.7$ \\
\hline BW21 & -23 & nd & 1.9 & $<1.3$ & $<.7$ \\
\hline BW21 & -48 & nd & 1.3 & $<1.3$ & $<.7$ \\
\hline
\end{tabular}




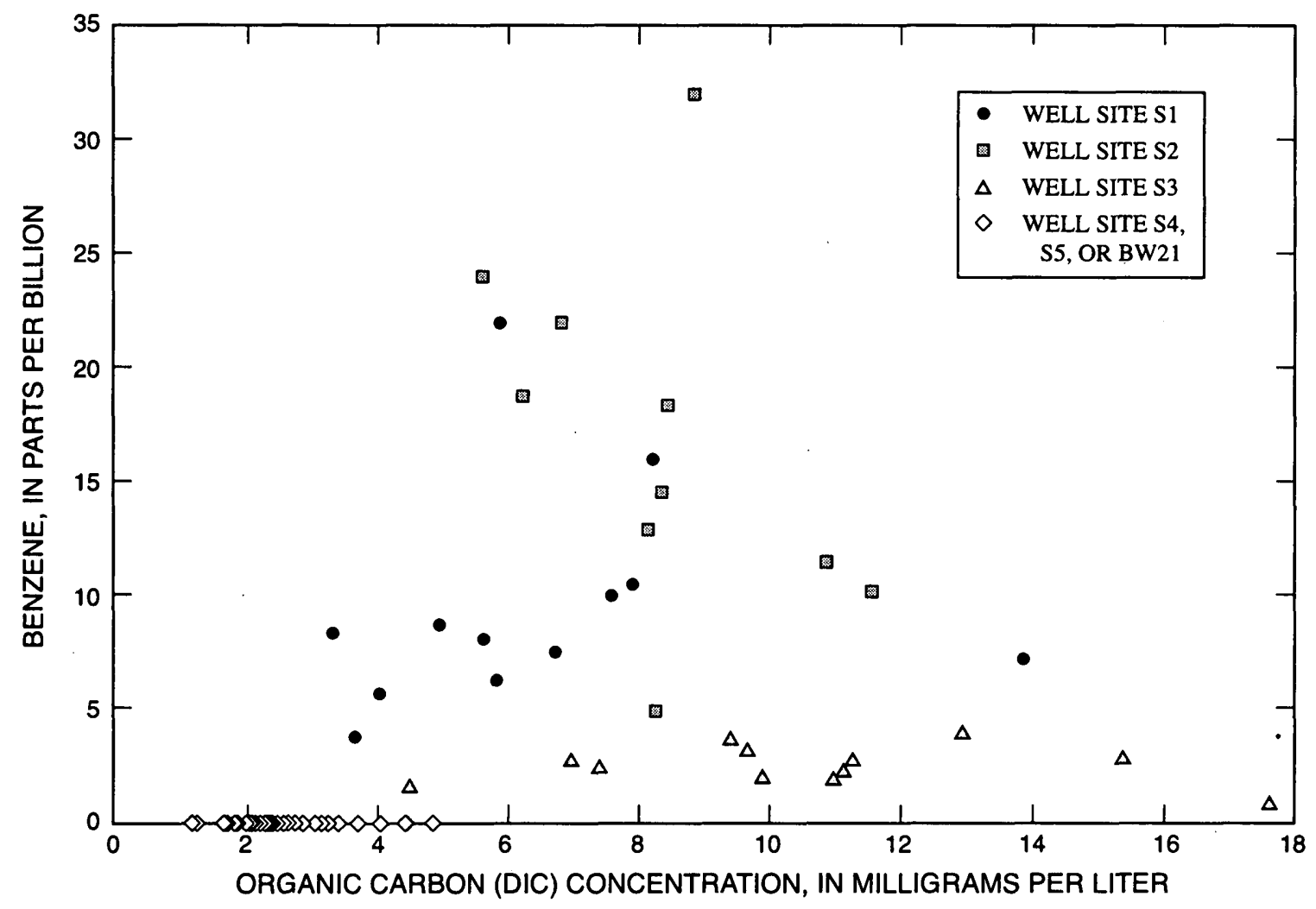

Figure 9. Relation between benzene and dissolved organic carbon (DOC) in ground-water samples from Sseries wells in February 1993, August 1993, and May 1994, Diego Garcia Atoll. 


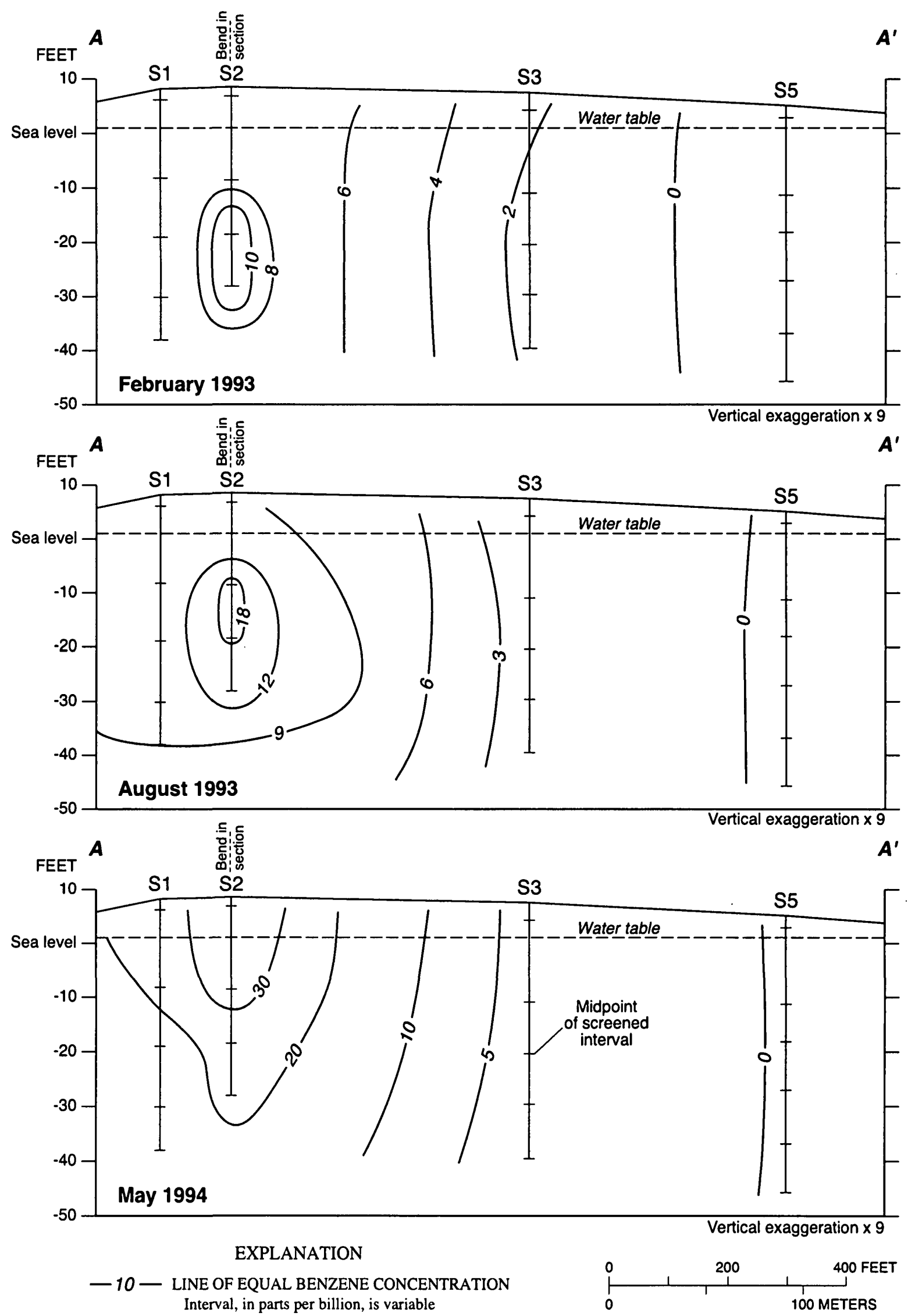

Figure 10. Hydrologic sections of benzene concentration at well sites S1, S2, S3, and S5 in February 1993, August 1993, and May 1994, Diego Garcia Atoll. Line of section shown in figure 2. 
Table 8. Concentrations of volatile organic carbon compounds in vapor and water samples, Diego Garcia Atoll

[Values are in parts per billion; measurements by gas chromatograph with a photoionization detector; --, no sample collected; nd, no detection; n.a., not applicable; tr, trace]

\begin{tabular}{|c|c|c|c|c|c|c|c|}
\hline \multirow{2}{*}{$\begin{array}{c}\text { Well or type } \\
\text { of sample }\end{array}$} & \multirow{2}{*}{$\begin{array}{c}\text { Altitude } \\
\text { (feet) }\end{array}$} & \multirow{2}{*}{$\begin{array}{c}\text { Water or } \\
\text { vapor } \\
\text { sample }\end{array}$} & \multicolumn{3}{|c|}{ February 1993} & \multirow{2}{*}{$\frac{\text { August } 1993}{\text { Benzene }}$} & \multirow{2}{*}{$\begin{array}{l}\text { May } 1994 \\
\text { Benzene }\end{array}$} \\
\hline & & & Benzene & Xylene $^{1}$ & Toluene $^{1}$ & & \\
\hline $\mathrm{S} 1$ & n.a. & vapor & -- & -- & -- & 6.6 & 5.0 \\
\hline S1 & -9 & water & 7.2 & 14.3 & nd & 10 & 22 \\
\hline S1 & -20 & water & 7.5 & 13.7 & nd & 11 & 16 \\
\hline $\mathrm{S} 1$ & -31 & water & 6.3 & 13.4 & nd & 8.1 & 8.7 \\
\hline S1 & -39 & water & 5.7 & 7.1 & nd & 3.8 & 8.4 \\
\hline $\mathrm{S} 2$ & n.a. & vapor & high & -- & -- & 7 & 45 \\
\hline $\mathrm{S} 2$ & -9 & water & 12 & 0.4 & 0.8 & 18 & 32 \\
\hline $\mathbf{S} 2$ & -19 & water & 5 & 1.2 & 0.2 & 19 & 24 \\
\hline $\mathrm{S} 2$ & -29 & water & 10 & 0.6 & 6.3 & 15 & 22 \\
\hline S3 & n.a. & vapor & 2.6 & 2.3 & nd & 2.2 & 3.8 \\
\hline S3 & -11 & water & 0.8 & 0.3 & 0.8 & 2.8 & 3.9 \\
\hline S3 & -21 & water & 1.9 & 1.0 & nd & 2.7 & 3.7 \\
\hline S3 & -30 & water & 2.0 & 1.4 & 0.4 & 2.2 & 3.2 \\
\hline S3 & -40 & water & 1.6 & 0.6 & 0.1 & 2.7 & 2.4 \\
\hline $\mathrm{S} 4$ & n.a. & vapor & 2.8 & nd & nd & $\mathrm{tr}$ & nd \\
\hline $\mathrm{S} 4$ & -11 & water & nd & nd & nd & nd & nd \\
\hline S4 & -21 & water & nd & nd & nd & nd & nd \\
\hline S4 & -31 & water & nd & nd & nd & nd & nd \\
\hline S4 & -41 & water & nd & nd & nd & nd & nd \\
\hline S5 & n.a. & vapor & - & - & - & nd & nd \\
\hline S5 & -11 & water & nd & nd & nd & nd & nd \\
\hline S5 & -18 & water & nd & nd & nd & nd & nd \\
\hline S5 & -27 & water & nd & nd & nd & nd & nd \\
\hline S5 & -37 & water & nd & nd & nd & nd & nd \\
\hline S5 & -46 & water & nd & nd & nd & nd & nd \\
\hline BW21 & -8 & water & nd & nd & nd & nd & nd \\
\hline BW21 & -23 & water & nd & nd & nd & nd & nd \\
\hline BW21 & -48 & water & nd & nd & nd & nd & nd \\
\hline Seawater & n.a. & water & nd & nd & nd & nd & nd \\
\hline Pond & n.a. & water & nd & nd & nd & nd & nd \\
\hline C1-1 & n.a. & vapor & -- & -. & -- & nd & nd \\
\hline $\mathrm{C} 1-1$ & n.a. & water & nd & nd & nd & nd & nd \\
\hline $\mathrm{Cl}-2$ & n.a. & vapor & -- & -- & -. & nd & nd \\
\hline $\mathrm{Cl}-2$ & n.a. & water & 4.9 & -- & -- & 5.0 & 0.5 \\
\hline C2-1 & n.a. & vapor & high & -- & -- & high & 32 \\
\hline C2-1 & n.a. & water & fuel & -- & -- & fuel & fuel \\
\hline C3-1 & n.a. & vapor & -- & -- & -- & nd & nd \\
\hline C3-1 & n.a. & water & -- & -- & -. & $\operatorname{tr}$ & $\operatorname{tr}$ \\
\hline C3-2 & n.a. & vapor & nd & nd & nd & nd & nd \\
\hline C3-3 & n.a. & vapor & -- & -. & -- & $\mathrm{tr}$ & tr \\
\hline C3-3 & n.a. & water & $\operatorname{tr}$ & -- & -- & $\mathrm{tr}$ & $\mathrm{tr}$ \\
\hline
\end{tabular}


Table 8. Concentrations of volatile organic carbon compounds in vapor and water samples, Diego Garcia Atoll-Continued

[Values are in parts per billion; measurements by gas chromatograph with a photoionization detector; --, no sample collected; nd, no detection; n.a., not applicable; tr, trace]

\begin{tabular}{|c|c|c|c|c|c|c|c|}
\hline \multirow{2}{*}{$\begin{array}{l}\text { Well or type } \\
\text { of sample }\end{array}$} & \multirow{2}{*}{$\begin{array}{c}\text { Altitude } \\
\text { (feet) }\end{array}$} & \multirow{2}{*}{$\begin{array}{c}\text { Water or } \\
\text { vapor } \\
\text { sample }\end{array}$} & \multicolumn{3}{|c|}{ February 1993} & \multirow{2}{*}{$\begin{array}{c}\text { August } 1993 \\
\text { Benzene }\end{array}$} & \multirow{2}{*}{$\begin{array}{l}\text { May } 1994 \\
\text { Benzene }\end{array}$} \\
\hline & & & Benzene & Xylene $^{1}$ & Toluene $^{1}$ & & \\
\hline C3-4 & n.a. & vapor & -- & -- & -- & nd & nd \\
\hline C3-4 & n.a. & water & nd & nd & nd & nd & nd \\
\hline C3-5 & n.a. & vapor & -- & -- & -- & nd & -- \\
\hline C3-5 & n.a. & water & nd & nd & nd & nd & nd \\
\hline C3-6 & n.a. & vapor & -- & -- & -- & nd & nd \\
\hline C3-6 & n.a. & water & nd & nd & nd & nd & nd \\
\hline C4-1 & n.a. & vapor & -- & - & -- & nd & nd \\
\hline C4-1 & n.a. & water & nd & nd & nd & nd & nd \\
\hline $\mathrm{C} 4-2$ & n.a. & vapor & -- & -- & -- & nd & -- \\
\hline $\mathrm{C} 4-2$ & n.a. & water & -- & -- & -- & nd & -- \\
\hline C4-3 & n.a. & vapor & -- & -- & -- & nd & nd \\
\hline $\mathrm{C} 4-3$ & n.a. & water & nd & nd & nd & nd & nd \\
\hline C5-1 & n.a. & vapor & -- & -- & -- & -- & nd \\
\hline C5-1 & n.a. & water & nd & nd & nd & nd & nd \\
\hline C6-1 & n.a. & vapor & -- & -. & -- & -. & nd \\
\hline C6-1 & n.a. & water & -- & -- & -- & nd & nd \\
\hline
\end{tabular}

\footnotetext{
${ }^{1}$ Xylene and toluene quantified by gas chromatograph-mass spectrometer (see table 9)
}

Notes:

$\begin{array}{ll}\text { S1 } & \text { All samples } \\ \text { S1-vapor } & \text { Feb. 1993 } \\ \text { S2 } & \text { All samples } \\ \text { S3 } & \text { All samples } \\ \text { C1-2 } & \text { May 1994 } \\ \text { C2-1 } & \text { All samples } \\ \text { C3-1 } & \text { May 1994 and Aug. 1993 } \\ \text { C3-2 } & \text { All samples } \\ \text { C3-3 } & \text { All samples } \\ \text { C3-5 } & \text { May 1994 } \\ \text { C4-2 } & \text { May 1994 }\end{array}$

Many hydrocarbons with unresolved high-level peaks
Line blocked, no sample
Many hydrocarbons with unresolved high-level peaks
Many hydrocarbons with unresolved low-level peaks
Water with few small peaks
Fuel in well, no water sample; many high-level peaks in vapor
Water with one low-level peak
No vapor sample, casing screened above ground
Unresolved low-level peaks in water and vapor
Hole in casing above ground, no vapor sample
Casing broken, plant roots in well, not sampled


Wells that were contaminated in February 1993

remained contaminated and showed increasing benzene concentrations. However, wells that were uncontaminated in February 1993 remained free of detectable contamination. The relatively coarse spatial distribution of wells prevents observing small-scale movement of the plume.

During the August 1993 and May 1994 trips, samples from wells that showed detectable benzene were subject to laboratory GC-MS analysis of VOC. These results are shown in table 9, as are the benzene concentrations measured in the field by GC-PID. For a given well, the laboratory GC-MS analysis gave lower benzene values than the field GC-PID because field GCPID is less efficient at separating compounds, so the benzene peak contains some non-benzene compounds.

Site $\mathrm{S} 2$ had the highest concentration of contaminants, followed closely by S1. Site S3 had the lowest concentration of volatile organic compounds. Typically, aromatic compounds dominated the VOC pool.

Because JP-5 is a relatively heavy distillate, it is not surprising that benzene was in much lower concentrations than several other aromatic compounds, and typically constituted less than 5 percent of the total mass of identified aromatic compounds. Naphthalene was consistantly the most common aromatic compound identified, and typically constituted 30 to 40 percent of the total mass of identified aromatic compounds; other common compounds were ethyl benzene, propylbenzenes (isoand $\mathrm{n}-$ ), trimethyl benzenes, and tetramethyl benzenes.

\section{EVALUATION OF MICROBIAL RESPIRATION AND FUEL DEGRADATION}

\section{Excess DIC as an Indicator of Organic Respiration}

The concentration of DIC in water samples from unsaturated and saturated parts of the aquifer was calculated using WATEQ4F (Ball and Nordstrom, 1991) and measured concentrations of major ions, $\mathrm{pH}$, and temperature. These results are shown in table 10 (at end of report), along with the calculated charge balance and saturation state with respect to the mineral aragonite.

The average charge balance for all samples was 3.1 percent, with a range of -2.5 percent to 20.6 percent. A histogram of the calculated charge balances is shown in figure 11. Most samples are in the range of 2 to 4 per- cent. The average positive charge balance indicates a slight bias in the analysis of major ions, either through overdetermination of cations (predominantly $\mathrm{Ca}^{2+}$ and $\mathrm{Mg}^{2+}$ ) or underdetermination of anions (predominantly titration alkalinity). The charge balance for most samples was quite reasonable, and indicates that the analytical results are accurate. Samples collected by lysimeter at site S1 had the worst charge balances; the results of this analysis must be considered suspect.

High concentrations of DIC were found in all water samples. This high DIC results from both the dissolution of carbonate mineral and the oxidation of organic carbon to inorganic carbon. The dissolution of carbonate minerals can be calculated from the stoichiometric release of bivalent cations $\left(\mathrm{Ca}^{2+}, \mathrm{Mg}^{2+}\right.$, and $\left.\mathrm{Sr}^{2+}\right)$. The difference between the total DIC and that released from mineral dissolution is attributed to organic respiration. For each water sample, the amount of organic respiration and mineral dissolution is given in table 10.

The relation between the release of DIC from respiration and the release of DIC from mineral dissolution is shown in figure 12. The data appear to define a reaction path whereby the release of DIC (and acidity) from the oxidation of organic material stimulates the dissolution of carbonate minerals. Although data from the unsaturated part of the aquifer (sampled by lysimeter) shows slightly greater scatter, the trend for all data can be described by a line having the regression (Model II in Sokal and Rohlf, 1969) equation: Org-C $=1.7^{*}$ Carb-C - $1.7\left(n=85, \mathrm{r}^{2}=0.91\right)$.

The saturation state of the water with respect to aragonite (table 10) or calcite (not shown) does not change with increasing amounts of carbonate mineral dissolution. Because most water samples were slightly oversaturated with respect to aragonite, it appears that the reactive phase is a high- $\mathrm{Mg}$ calcite. This is supported by the high $\mathrm{Mg}^{+2}: \mathrm{Ca}^{+2}$ ratios in ground-water samples.

The highest concentrations of DIC were found in samples in the contaminated part of the aquifer. A hydrologic section of DIC from respiration is shown in figure 13. As with figure 10 , some care must be taken in the interpretation because the section does not fall directly on a flow path and samples were not collected in the presumed center of the plume. However, when considered with measured contaminant concentrations, the data indicate that the presence of fuel contaminants 


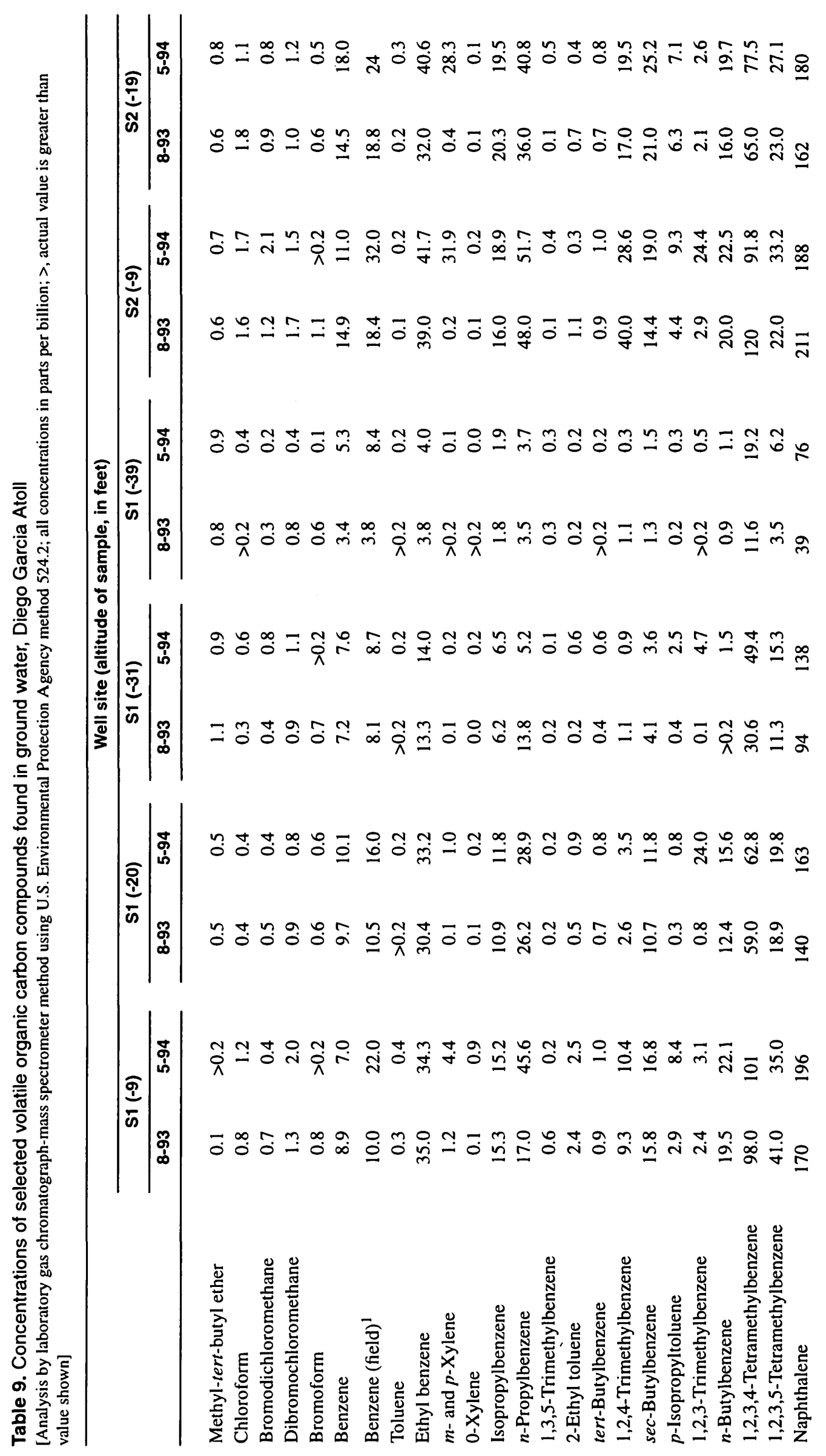




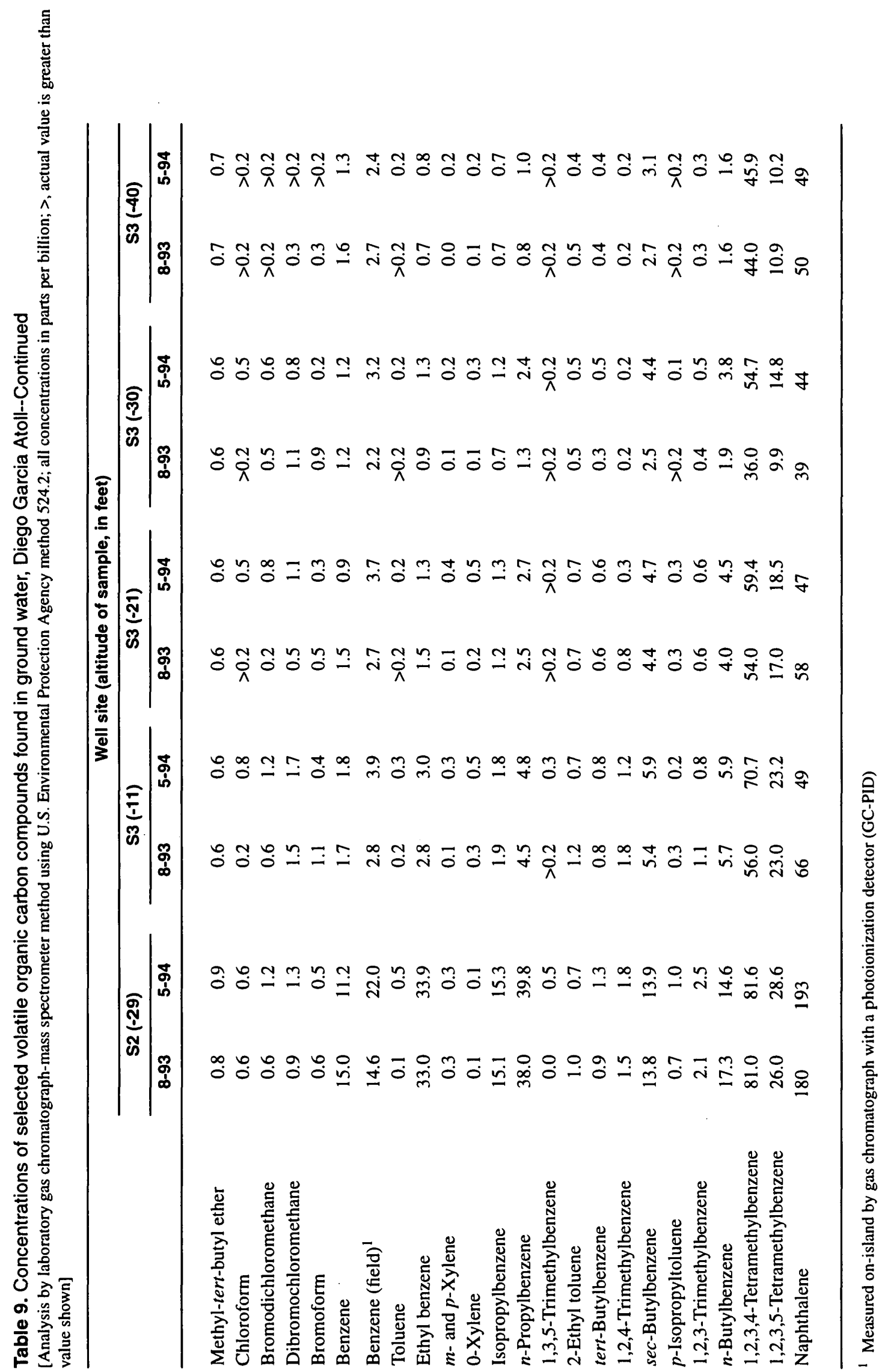




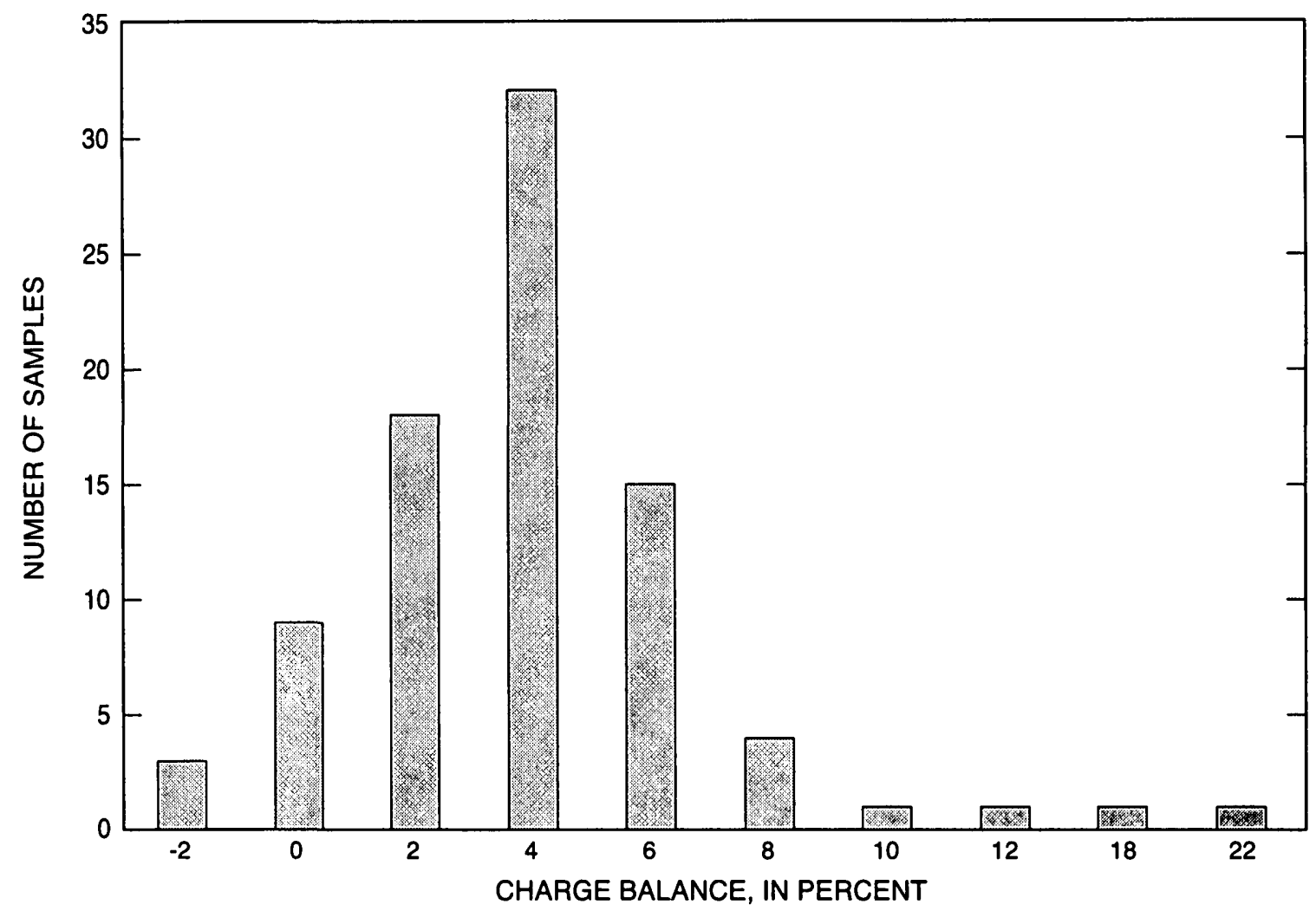

Figure 11. Distribution of charge balance calculated using WATEQ4F (Ball and Nordstrom, 1991) for ground-water samples collected in February 1993, August 1993, and May 1994, Diego Garcia Atoll.

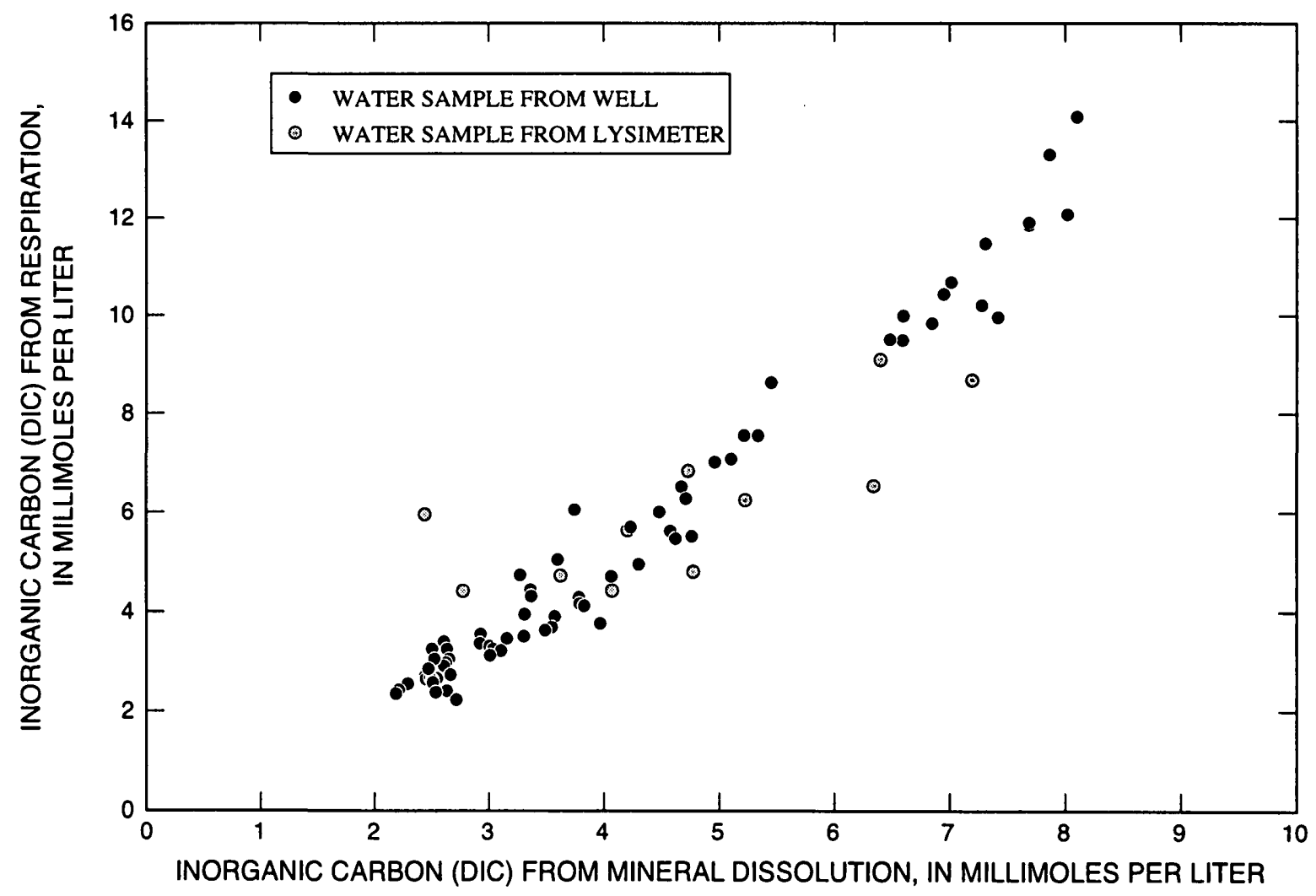

Figure 12. Relation between dissolved inorganic carbon (DIC) released from carbonate mineral dissolution and dissolved inorganic carbon (DIC) released from microbial respiration for ground-water samples collected in February 1993, August 1993, and May 1994, Diego Garcia Atoll. 


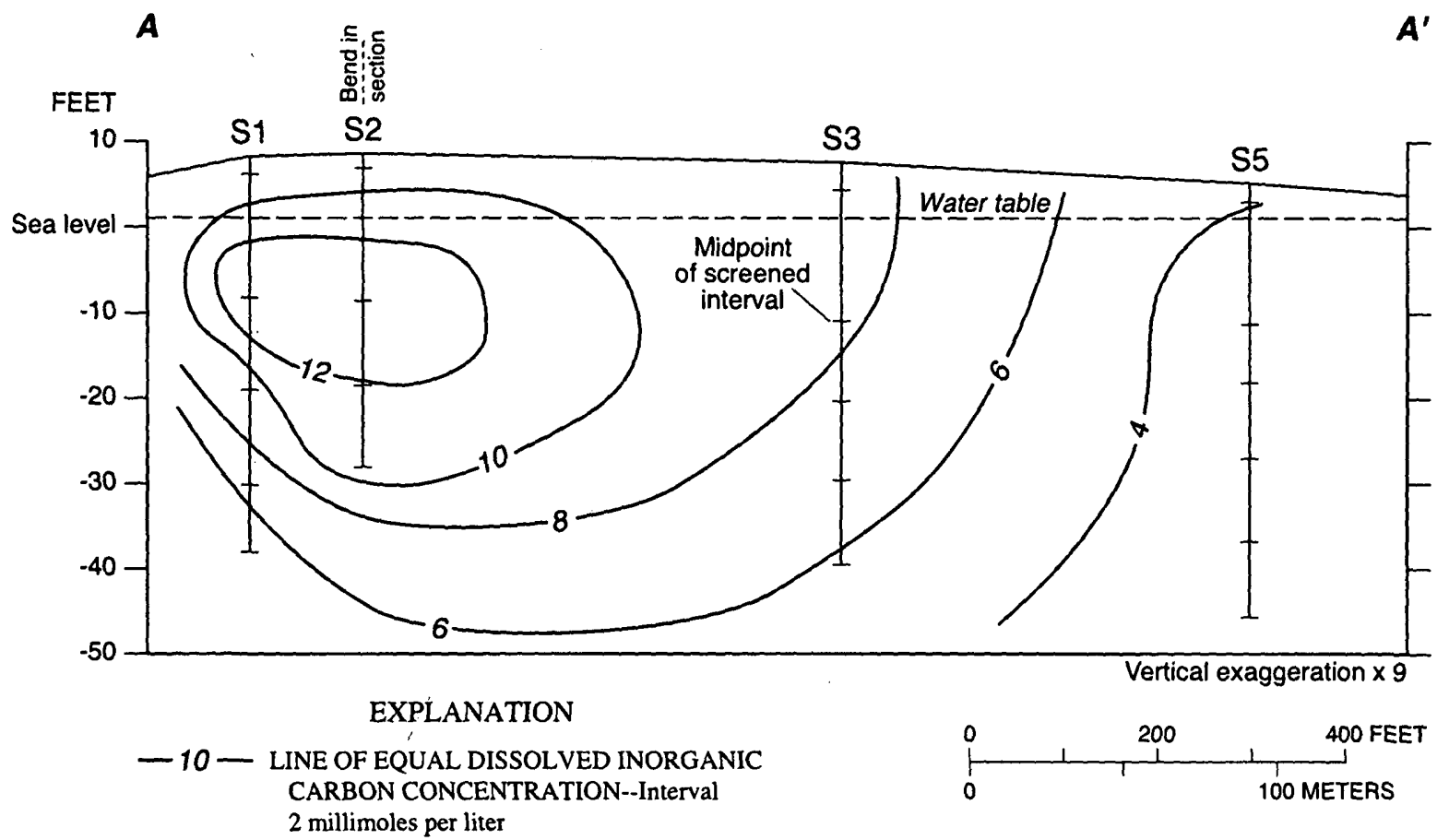

Figure 12. Hydrologic section of dissolved inorganic carbon concentration at well sites $\mathrm{S} 1, \mathrm{S2}, \mathrm{S} 3$, and $\mathrm{S} 5$ in May 1994, Diego Garcia Atoll. Line of section shown in figure 2. 
leads to much higher levels of organic respiration, and that bacterial activity in the aquifer is actively degrading the fuel.

At well sites S1 and S2, slightly more than half of the increase in DIC from respiration appeared to occur in the unsaturated zone. Although the highest levels of respired DIC were observed in the water table, it may be that most activity occurs in the unsaturated zone or very close to the water table. The tidal oscillations in the water table may provide a favorable environment for microbial respiration, with rewetting over a large interval followed by reexposure to gas phases in the unsaturated zone. At site S5, the unsaturated zone waters had higher levels of respired DIC than water from below the water table. It may be that transient storms with large rainfall create pulses of recharge than do not undergo substantial reaction in the unsaturated zone, and that these fluids were not sampled by the lysimeters.

\section{Mechanisms of Microbial Oxidation}

Heterotrophic bacteria oxidize organic carbon as a source of energy; this oxidation requires the reduction of a terminal electron acceptor. Different terminal electron acceptors have different thermodynamic efficiencies, and yield differing amounts of energy. In order of decreasing yield, the most common terminal electron acceptors (and their associated metabolic pathways) are: oxygen (oxic respiration), nitrate (nitrate reduction), iron (iron reduction), sulfate (sulfate reduction), and other organic molecules (methanogenesis). Per molecule of glucose oxidized, the energy yield from methanogenesis is about 11 percent of the energy released during oxic respiration (Froelich and others, 1979). Given a sufficient amount of organic carbon and nutrients for growth, bacteria will sequentially utilize the most energy-yielding terminal electron acceptor until it is depleted, then switch to the next most efficient acceptor.

At an atoll such as Diego Garcia, this process is somewhat simplified by the absence of appreciable quantities of iron. Furthermore, nitrate tends to be found in relatively low concentrations. Thus, the primary mechanisms of microbial oxidation are oxic respiration, sulfate reduction, and methanogenesis.

Oxygen concentrations in the unsaturated zone were considerably lower than in the atmosphere, indicating high amounts of oxic respiration in the unsatur- ated zone. Vapor samples from the most contaminated sites ( $\mathrm{S} 1$ and $\mathrm{S} 2$ ) tended to have the lowest $\mathrm{O}_{2}$ concentrations. It appears as if metabolic activity in the unsaturated part of the aquifer is high enough to consume most of the oxygen. The flow of oxygen into the aquifer is enhanced by the diurnal oscillations in water level, which displace about half of the volume of the unsaturated zone with every tide cycle. However, this exchange may be retarded throughout much of the area by the thick cement paving of the South Ramp and taxiway and also by the asphalt-covered stormwater collection areas between the ramp and taxiway.

Because oxygen concentrations in the unsaturated part of the aquifer are low, water recharging the basal aquifer arrives with little oxygen. Concentrations of dissolved oxygen from well samples were mostly at or near the level of detection. It is unlikely that significant amounts of organic carbon are respired by oxic respiration below the water table. If recharge water was in equilibrium with a soil vapor $\mathrm{O}_{2}$ concentration of 5 percent (table 3 ), the consumption of this oxygen would produce less than $0.06 \mathrm{mM}$ of DIC. Although most of the respiration may be occurring in the unsaturated zone, there appears to be significant respiration within the saturated aquifer. Because $\mathrm{O}_{2}$ concentrations are low, the oxidation of organic carbon in the saturated part of the aquifer is occurring principally by mechanisms other than oxic respiration.

Concentrations of $\mathrm{H}_{2} \mathrm{~S}$ in water from wells at contaminated sites (S1, S2, and S3) typically exceeded 5 $\mathrm{mg} / \mathrm{L}$. Assuming a 2:1 reaction stoichiometry between organic carbon and $\mathrm{SO}_{4}{ }^{2-}$, the observed rise would contribute about $0.3 \mathrm{mM}$ of DIC due to respiration.

Although this is more than can be attributed to oxic respiration, it is not enough to explain the apparent increase in DIC from respiration in the saturated zone.

The high levels of $\mathrm{CH}_{4}$ observed in the soil vapor at the most active (and contaminated sites) indicate that methanogenesis is an important contributor to total microbial respiration. Because methanogenesis is a strictly anaerobic process, it is unlikely to be a significant process in the unsaturated part of the aquifer, except perhaps in the most contaminated or microbially active parts of the unsaturated zone.

Taken as a whole, the data demonstrate that microbial activity exerts a major control on the aquifer geochemistry at the Air Operations area. Sites contaminated by fuel have much higher levels of microbial 
activity than uncontaminated sites, indicating that the fuel is being oxidized as an energy source for microbial metabolism. Most activity appears to be in the unsaturated part of the aquifer. The rate of this activity significantly lowers the concentration of oxygen. Oxygen concentrations typically were about 4 percent in much of the unsaturated zone. This may represent a metabolic threshold below which oxic respiration of organic matter in the aquifer slows or may reflect the average concentration of $\mathrm{O}_{2}$ across oxic and anoxic

microenvironments. It is likely the overall amount of oxic respiration is determined by the physics of oxygen delivery to the aquifer. Following oxygen depletion, denitrification and sulfate reduction account for minor amounts of the microbial respiration. However, because the pools of nitrate and sulfate are small, methanogenesis must be the predominant pathway for microbial respiration following the depletion of oxygen. The high concentrations of $\mathrm{CH}_{4}$ in the soil vapor at the most active sites support this interpretation. Because methanogenesis is a low-energy yielding process and the most easily degraded compounds will be oxidized first, it is likely that although microbial oxidation is clearly enhanced at sites contaminated by fuel, the breakdown of compounds that are resistant to oxidation will proceed slowly if at all.

\section{Stormwater Receiving Pond}

A pond at the north end of the South Ramp receives rain runoff from the ramp and parts of the taxiway. Rainwater reaches the pond through an underground culvert and storm drains located in asphalt swales between the ramp and taxiway. The pond is connected with the lagoon by a valve that allows discharge of rainwater but nominally prevents inflow of seawater. The pond is brackish, with a $\mathrm{Cl}^{-}$concentration corresponding to 1 to 3 percent that of seawater. The pond contains an active population of phytoplankton, as indicated by the green residue on filter paper, the high concentrations of dissolved $\mathrm{O}_{2}$, the high $\mathrm{pH}$ values, and the low concentrations of DIC.

Free-phase fuel was observed discharging along the margin of the pond closest to the ramp in June 1991, February 1993, August 1993, and May 1994. Fuel also appears to be entering the pond from the culvert. The bottom of the pond is covered with a thick layer of organic material that appears to be a microbial mat. Dis- turbing this mat near the edge causes release of both free-phase fuel and gas bubbles. Analysis of the gas bubbles by GC-PID in the field revealed high concentrations of VOC compounds. It appears that there is both a surface and subsurface flux of fuel contaminants into the pond.

Analysis with GC-PID in February 1993, August 1993, and May 1994 did not detect any VOC compounds in water collected from a depth of 6 in. in the pond (pond depth estimated at 6 to $10 \mathrm{ft}$ ). Samples were collected about $50 \mathrm{ft}$ from the edge of the pond. In August 1993, a series of five samples was collected from the pond edge to a distance of $50 \mathrm{ft}$. The sample closest to the edge showed a trace of VOC contamination; all others were clean. Despite having received a steady flux of fuel for several years, it appears the contaminants are not accumulating in pond waters. It is likely that volatilization and degradation prevent this accumulation. Although the assimilative capacity of the pond is unknown, the discharge of contaminants to pond waters is not necessarily detrimental to pond ecology. Contaminants do not appear to persist in the pond or to be transported to the lagoon.

\section{Degradation of Aromatic Hydrocarbons}

Concentrations of DIC and other compounds associated with microbial metabolism demonstrate that fuel is actively being degraded by naturally occurring bacteria within the aquifer. Although aromatic compounds are a minor component in JP-5, they pose the greatest health risk due to the combination of their high toxicity and solubility. Also, benzene is considered resistant to microbial degradation, particularly under the anaerobic conditions that prevail at Diego Garcia. Consequently, the degradation of aromatic compounds merits special attention. Degradation was evaluated using the GC-MS analysis for VOC conducted at contaminated wells in August 1993 and May 1994.

Table 11 summarizes the concentrations and abundances of selected aromatic compounds. Also shown are various ratios within a sample between compounds, as well as the changes in compounds and ratios between compounds at different wells at a given site. Finally, the concentration of benzene is calculated by assuming conservative behavior of compounds considered less susceptible to degradation than benzene (Wilson and others, 1994). 


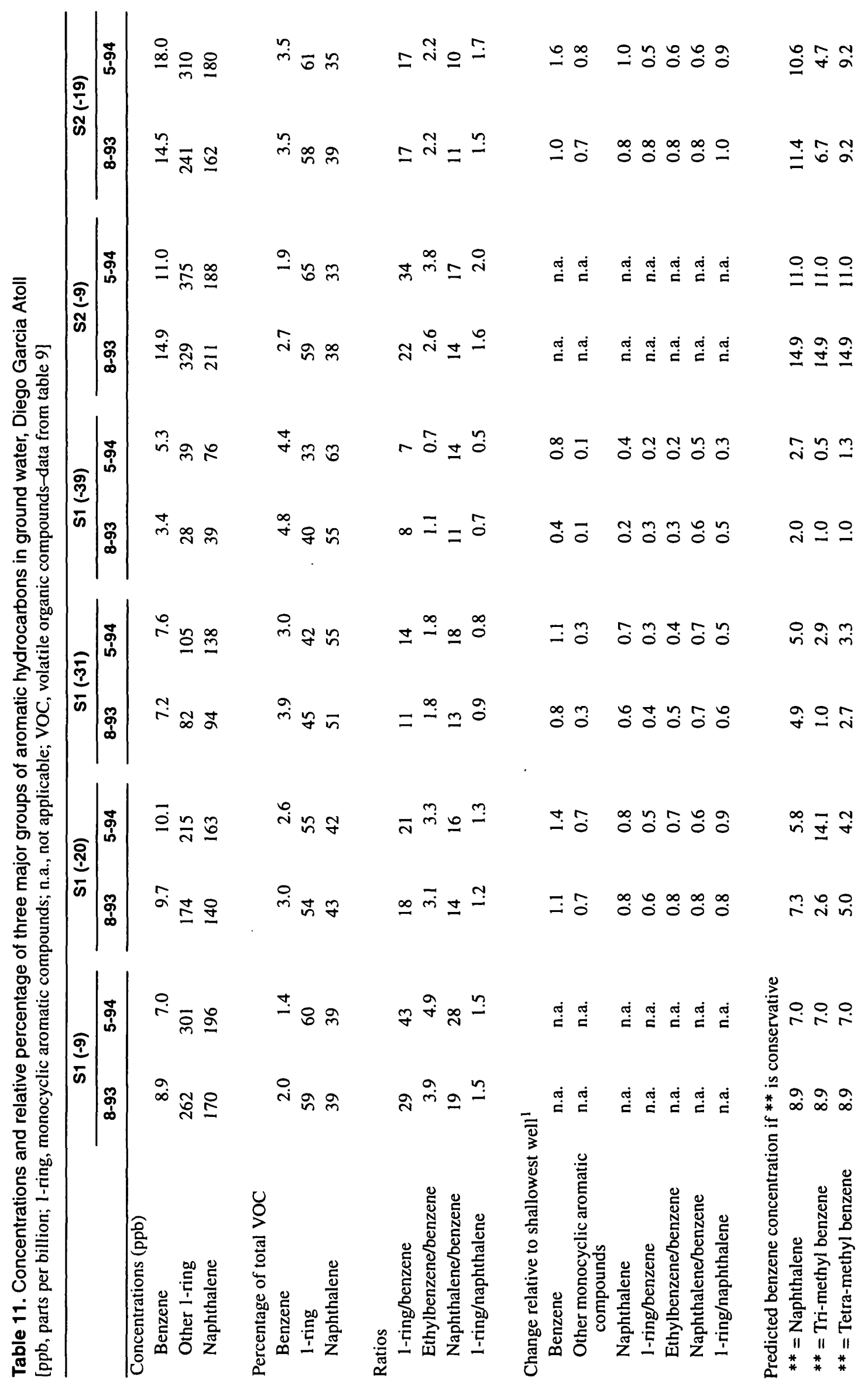

Evaluation of Microbial Respiration and Fuel Degradation 31 


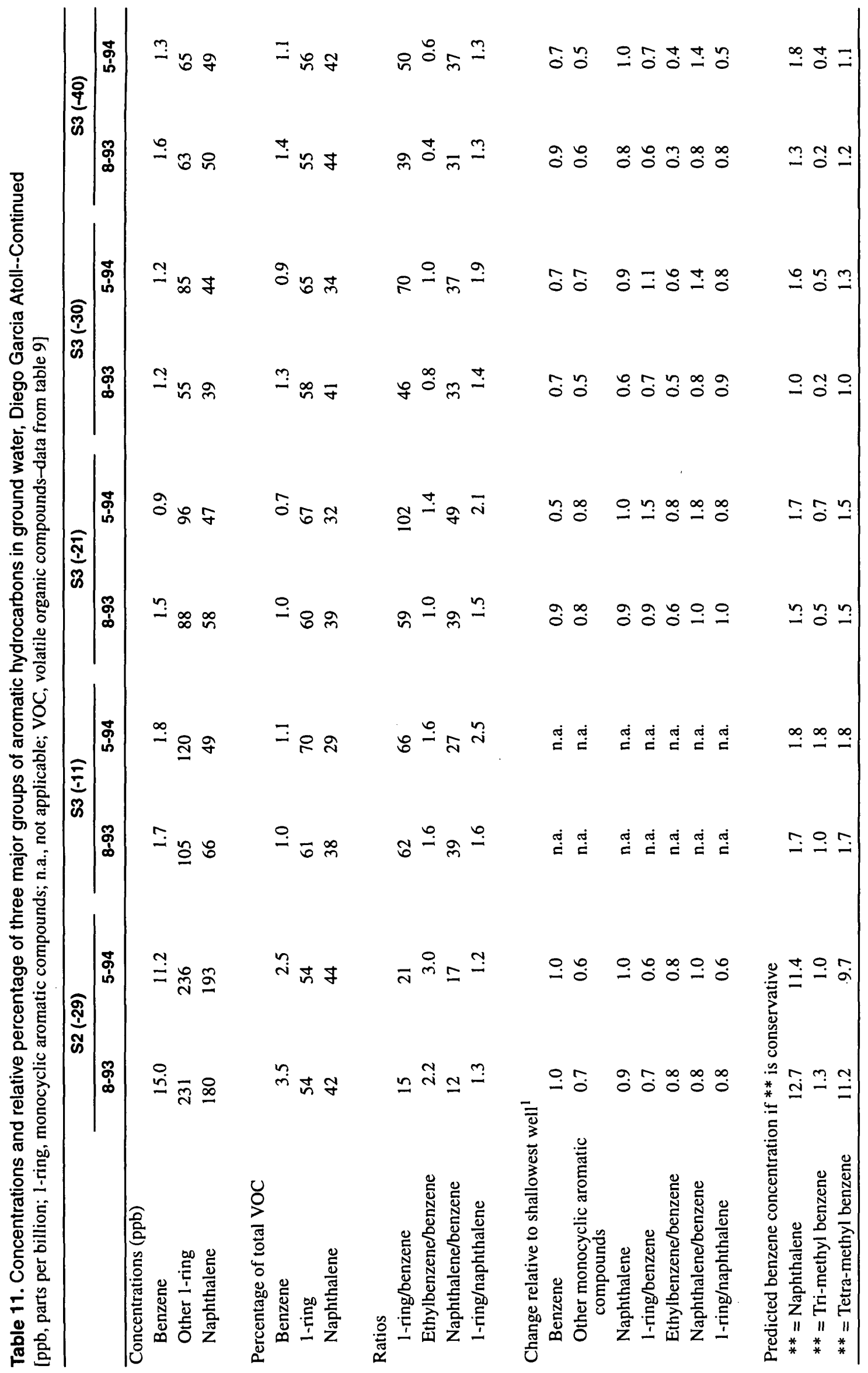


The concentrations of the predominant aromatic groups and their relative percentages showed a pattern with depth at all three sites. Although concentrations tended to decrease with depth, it appears the relative proportion of naphthalene increased with depth. The relative percentage of benzene also showed a slight tendency to increase with depth at given site and time, suggesting that the other monocyclic aromatics are being selectively degraded. This can also be seen by looking at the ratios of major groups and compounds at different depths and sites. Relative to benzene and naphthalene, other monocyclic aromatic hydrocarbons as a whole, as well as ethylbenzene, show a decrease with depth (ethylbenzene:naphthalene ratio not shown in table 11). Relative to benzene, naphthalene also shows a decrease with depth at sites S1 and S2, but not at S3. Using other compounds to predict a benzene concentration also indicates that benzene is persistent relative to naphthalene as well as other monocyclic aromatic hydrocarbons (including trimethyl- and tetramethyl benzenes). The predicted concentration is consistently higher than measured, indicating that benzene is recalcitrant relative to all other compounds considered.

Data from table 9 show a clear decrease in toluene and xylene both with depth at a site and with decreasing levels of contamination. The preferrential degradation of these compounds relative to benzene is well documented (Chapelle, 1993). However, trimethyl-, tetramethyl-, and ethylbenzene constituted the bulk of the pool of monocyclic aromatics. The apparent degradation of these compounds relative to benzene is surprising because they are considered less susceptible to microbial breakdown (Wilson and others, 1994). The same is true with respect to naphthalene. It is possible that differential partitioning between the free-fuel phase and water (and perhaps selective transport in the aquifer) of specific compounds explains this result. Nevertheless, the data do not indicate that the biodegradation of benzene is a significant phenomenon. Factors controlling the distribution and concentration of aromatic hydrocarbons need to be clarified by additional monitoring over time and removal of the free-phase fuel from the aquifer.

\section{SUMMARY AND CONCLUSIONS}

A jet fuel leak, detected in 1991, contaminated part of the aquifer near the South Ramp of Diego Garcia. Analyses of major ions, gases, nutrients, and fuel constituents were done to chemically characterize the contamination. Organic and inorganic reactions in the aquifer were deduced from chemical analysis of water and gas from the contaminated and the uncontaminated parts of the aquifer. The study determined the amount of respiration that has occurred at sampling locations.

Chemicals such as oxygen, hydrogen sulfide, and methane that are diagnostic to specific types of metabolism provide insight into respiratory processes in the aquifer. In contaminated areas, the ratios of specific contaminant compounds give an independent measure of the extent of contaminant degradation. A network of 23 wells was used to collect water samples for study of the chemistry of the saturated part of the aquifer. Unsaturated zone vapor and water samples were collected using five vapor points and six lysimeters installed at selected sites. Samples were collected in February 1993, August 1993, and May 1994.

Ground-water samples were warm, and had low concentrations of oxygen and high concentrations of hydrogen sulfide relative to atmospheric equilibrium. Gas from the unsaturated zone also had low concentrations of oxygen; samples near contaminated area had high levels of methane. Ground-water samples had high concentrations of bivalent cations and inorganic nutrients, resulting from inorganic dissolution of carbonate minerals and from microbial oxidation of organic material. Both processes occurred to a much higher degree at contaminated sites. The high levels of bacterial respiration at contaminated sites indicated that hydrocarbons were being actively degraded by naturally occurring bacteria in the aquifer.

Hydrocarbons were found dissolved in ground water, as a vapor phase in the unsaturated zone, and floating as a free-phase layer on top of the water table. Limited data indicate that, despite the recovery of more than 134,000 gallons, substantial fuel remained in the aquifer as a free-phase layer on the water table. Benzene concentrations have shown a steady increase in both ground water and soil vapor. Consideration of various aromatic compounds such as naphthalene, trimethyl benzene, and tetramethyl benzene, indicates that while hydrocarbons as a whole were being degraded, there was no evidence for the degradation of benzene under the reducing conditions observed in the aquifer. 


\section{REFERENCES CITED}

Andrae, M.O., Charlson, R.J., Bruynseels, F., Storms, H., Van Grieken, R., and Maenhaut, W., 1986, Internal mixture of sea salt, silicates, and excess sulfate in marine aerosols: Science, v. 232, p. 1620-1623.

Ball, J.W., and Nordstrom, D.K., 1991, WATEQ4F: User's manual with revised thermodynamic data base and test cases for calculating speciation of major, trace and redox elements in natural waters: U.S. Geological Survey Open-File Report 91-183, 208 p.

Ballestero, T.P., Fiedler, F.R., and Kinner, N.E., 1994, An investigation of the relationship between actual and apparent gasoline thickness in a uniform sand aquifer: Ground Water, v. 32, p. 708-718.

Chapelle, F.H., 1993, Ground-water microbiology and geochemistry: New York, John Wiley, 424 p.

Drever, J.I., 1988, The geochemistry of natural waters (2d ed.): Englewood Cliffs, N.J, Prentice-Hall, 437 p.

Emery, K.O., Tracy, J.I., Jr., and Ladd, H.S., 1954, Geology of Bikini and nearby atolls: U.S. Geological Survey Professional Paper 260-A, 256 p.

Froelich, P.N., Klinkhammer, G.P., Bender, M.L., Luedtki, N.A., Heath, R., Cullin, P., Dauphin, P., Hammond, D., Hartman, B., and Maynard, V., 1979, Early oxidation of organic matter in pelagic sediments of the eastern equatorial Atlantic: Suboxic diagenesis: Geochimica et Cosmochimica Acta, v. 43, p. 1075-1090.

Hamlin, S.N., and Anthony, S.S., 1987, Ground-water resources of the Laura area, Majuro atoll, Marshall Islands: U.S. Geological Survey Water-Resources Investigations Report 87-4047, 69 p.

Hem, J.D., 1989, Study and interpretation of the chemical characteristics of natural waters: U.S. Geological Survey Professional Paper 2254, 263 p.

Hollibaugh, J.T., Buddemeier, R.W., and Smith; S.V., 1991, Contributions of colloidal and high molecular weight dissolved material to alkalinity and nutrient concentra- tions in shallow marine and estuarine ecosystems: Marine Chemistry, v. 34, p. 1-27.

Hunt, C.D., Jr., 1991, Climate-driven saltwater intrusion in atoll, in Peters, H.J., ed, Ground Water in Pacific Rim Countries: Symposium of the Irrigation and Drainage Division - American Society of Civil Engineers, Honolulu, Hawaii, July 23-25, 1991, p. 43-49.

Huntley, D., Wallace, J.W., and Hawk, R.N., 1994, Nonaqueous phase hydrocarbon in a fine-grained sandstone: 2 . Effect of local sediment variability on the estimation of hydrocarbon volumes: Ground Water, v. 32, p. 778-783.

Kennett, J.P., 1982, Marine geology: Englewood Cliffs, N.J., Prentice-Hall, $752 \mathrm{p}$.

Krauskopf, K.B., 1979, Introduction to geochemistry (2d ed.): New York, McGraw-Hill, $617 \mathrm{p}$.

Morse, J.W., and Mackenzie, F.T., 1990, Geochemistry of sedimentary carbonates in Developments in Sedimentology 48: Amsterdam, Elsevier, 707 p.

Mouri, H., and Okada, K., 1993, Shattering and modification of sea-salt particles in the marine atmosphere: Geophysical Research Letters, v. 20, p. 49-52.

PRC Toups, 1983, Final submittal engineering study to evaluate potable water supply alternatives and groundwater yield at Diego Garcia, British Indian Ocean Territory, Volume II (prepared for U.S. Navy, Naval Facilities Engineering Command, Pacific Division, Pearl Harbor, Hawaii): Orange, Calif., PRC Toups, variously paged, 7 app.

Smith, S.V., Hollibaugh, J.T., Dollar, S.J., and Vink, S., 1991, Tomales Bay metabolism: C-N-P stoichiometry and ecosystem heterotrophy at the land-sea interface: Estuarine, Coastal and Shelf Science, v. 33, p. 223-257.

Sokal, R.R., and Rohlf, F.J., 1969, Biometry: San Francisco, Calif., W.H. Freeman, 776 p.

Tribble, G.W., 1997, Ground-water geochemistry of Kwajalein Island, Republic of the Marshall Islands, 1991: U.S. Geological Survey Water-Resources Investigations Report 97-4184, 47 p. 
Tribble, G.W., Sansone, F.J., and Smith, S.V., 1990, Stoichiometric modeling of carbon diagenesis within a coral reef framework: Geochimica et Cosmochimica Acta, v. 54, p. 2439-2449.

Tribble, G.W., Lee, R.W., Wydoski, D.S., Torikai, J.D., Hunt, C.D., Jr., 1996, Preliminary assessment of jet fuel contamination of an atoll aquifer, in Morganwalp, D.W., and Aronson, D.A., eds.: U.S. Geological Survey Toxic Substances Hydrology Program- Proceedings of the Technical Meeting, Colorado Springs, Colorado, September 20-24, 1993: U.S. Geological Survey Water-

Resources Investigations Report 94-4014.

Underwood, M.R., 1990, Atoll island hydrogeology: Conceptual and numerical models: Honolulu, Hawaii, University of Hawaii, Ph.D. dissertation, 205 p.

U.S. Environmental Protection Agency, 1989, Proposed rule, National primary and secondary drinking water regulations: U.S. Federal Register, v. 54, no. 97 , May 22, 1989, p. 22, 062-22, 160.

Vacher, H.L., and Quinn, T.M., eds., 1997, Geology and hydrogeology of carbonate islands. Developments in Sedimentology 54: Amsterdam, Elsevier, 933 p.

White, A.F., Peterson, M.L., and Solbau, R.D., 1990, Measurement and interpretation of low levels of dissolved oxygen in ground water: Ground Water, v. 28, p. 584590.

Wilson, J.T., Pfeffer, F.M., Weaver, J.W., Kampbell, D.H., Wiedemeier, T.H., Hansen, J.E., and Miller, R.N., 1994, Intrinsic bioremediation of JP-4 jet fuel, in Symposium on Intrinsic Bioremediation of Ground Water, Denver, Colorado, August 30-September 1, 1994: U.S Environmental Protection Agency Office of Research and Development EPA/540/R-94/515., August 1994, p. 60-72. 
Table 2. Field data and concentrations of dissolved $\mathrm{H}_{2} \mathrm{~S}$ and $\mathrm{O}_{2}$ in ground-water, rain, seawater, and pond samples, Diego Garcia Atoll

[Samples from above sea level at well sites $\mathrm{S} 1, \mathrm{~S} 2$, and $\mathrm{S} 5$ collected from the unsaturated zone using lysimeters; $\mathrm{ft}$, feet; gal, gallon; ${ }^{\circ} \mathrm{C}$, degrees Celsius; ppm, parts per million; --, not measured; n.a., not applicable]

\begin{tabular}{|c|c|c|c|c|c|c|c|c|}
\hline $\begin{array}{c}\text { Well site or } \\
\text { type of } \\
\text { sample } \\
\end{array}$ & $\begin{array}{c}\text { Altitude } \\
\text { (ft) }\end{array}$ & Date & Time & Volume (gal) & $\begin{array}{c}\text { Temperature } \\
\left({ }^{\circ} \mathrm{C}\right)\end{array}$ & pH & $\begin{array}{c}\mathrm{H}_{2} \mathrm{~S} \\
(\mathrm{ppm})\end{array}$ & $\begin{array}{c}\mathrm{O}_{2} \\
(\mathrm{ppm})\end{array}$ \\
\hline S1 & 6 & $2-2-93$ & 1555 & 0.04 & 30.9 & 7.12 & -- & -- \\
\hline S1 & 5 & $2-2-93$ & 1610 & 0.2 & 29.8 & 7.21 & -- & -- \\
\hline S1 & 5 & $8-21-93$ & 1440 & 0.2 & 30.2 & 7.07 & -- & -- \\
\hline S1 & 5 & $5-15-94$ & 1700 & 0.2 & 31.5 & 7.03 & -- & -- \\
\hline S1 & -9 & $1-30-93$ & 1105 & 9 & 28.9 & 6.88 & 2.3 & 0.6 \\
\hline S1 & -9 & $8-17-93$ & 1120 & 12 & 29.3 & 6.90 & 2.4 & 0.1 \\
\hline S1 & -9 & $5-8-94$ & 1158 & 9 & 29.0 & 6.76 & 2.4 & 0.1 \\
\hline S1 & -20 & $1-30-93$ & 1210 & 6 & 29.9 & 7.32 & 3.4 & 0.4 \\
\hline S1 & -20 & $8-17-93$ & 1015 & 9 & 29.1 & 7.29 & 5.4 & 0.2 \\
\hline S1 & -20 & $5-8-94$ & 1117 & 9 & 29.0 & 6.98 & 4.2 & 0.1 \\
\hline S1 & -31 & $1-30-93$ & 1310 & 8 & 29.2 & 7.47 & 5.2 & 0.3 \\
\hline S1 & -31 & $8-17-93$ & 930 & 12 & 28.8 & 7.54 & 6.4 & 0.2 \\
\hline S1 & -31 & $5-8-94$ & 1021 & 12 & 28.6 & 7.29 & 8.4 & 0.1 \\
\hline S1 & -39 & $1-30-93$ & 1415 & 8 & 29.3 & 7.58 & 3.8 & 0.4 \\
\hline S1 & -39 & $8-17-93$ & 840 & 9 & 28.7 & 7.59 & 5.2 & 0.1 \\
\hline S1 & -39 & $5-8-94$ & 928 & 9 & 28.2 & 7.48 & 7.6 & 0.1 \\
\hline S2 & 7 & $2-2-93$ & 1700 & 0.2 & 30.5 & 7.10 & -- & -- \\
\hline S2 & 7 & $8-21-93$ & 1455 & 0.2 & 30.1 & 6.85 & -- & -- \\
\hline S2 & 7 & $5-15-94$ & 1640 & 0.2 & 32.3 & 7.90 & -- & -- \\
\hline S2 & 6 & $2-2-93$ & 1720 & 0.2 & 30.5 & 7.16 & -- & -- \\
\hline S2 & 6 & $8-21-93$ & 1505 & 0.2 & 30.3 & 7.11 & -- & -- \\
\hline S2 & 6 & $5-15-94$ & 1620 & 0.3 & 31.9 & 6.96 & - & -- \\
\hline S2 & -9 & $2-2-93$ & 1100 & 12 & 29.2 & 6.79 & 2.0 & 0.1 \\
\hline S2 & -9 & 17-Aug-93 & 1402 & 9 & 29.2 & 6.85 & 2.6 & 0.1 \\
\hline S2 & -9 & 8-May-94 & 1543 & 9 & 29.8 & 6.72 & 2.3 & 0.1 \\
\hline S2 & -19 & $2-2-93$ & 1005 & 12 & 29.2 & 6.90 & 2.4 & 0.2 \\
\hline S2 & -19 & 17-Aug-93 & 1315 & 9 & 29.8 & 6.93 & 2.6 & 0.2 \\
\hline S2 & -19 & 8-May-94 & 1505 & 9 & 29.8 & 6.82 & 2.4 & 0.1 \\
\hline S2 & -29 & $2-2-93$ & 920 & 9 & 28.7 & 6.98 & 3.0 & 0.2 \\
\hline S2 & -29 & $8-17-93$ & 1222 & 9 & 29.6 & 6.96 & 3.7 & 0.2 \\
\hline S2 & -29 & $5-8-94$ & 1424 & 9 & 29.7 & 6.84 & 3.4 & 0.1 \\
\hline S3 & -11 & $2-1-93$ & 1350 & 12 & 31.4 & 6.92 & 7.2 & 0.1 \\
\hline S3 & -11 & $8-16-93$ & 1440 & 12 & 32.0 & 6.97 & 7.5 & 0.2 \\
\hline S3 & -11 & $5-7.94$ & 1311 & 12 & 32.1 & 6.90 & 7.4 & 0.1 \\
\hline S3 & -21 & $2-1-93$ & 1110 & 12 & 30.3 & 7.10 & 8.7 & 0.2 \\
\hline S3 & -21 & $8-16-93$ & 1348 & 15 & 31.1 & 7.07 & 8.8 & 0.1 \\
\hline S3 & -21 & $5-7-94$ & 1234 & 12 & 31.3 & 7.00 & 8.5 & 0.1 \\
\hline S3 & -30 & $2-1-93$ & 1000 & 10 & 29.9 & 7.12 & 10.0 & 0.1 \\
\hline S3 & -30 & $8-16-93$ & 1147 & 15 & 30.2 & 7.09 & 9.6 & 0.1 \\
\hline S3 & -30 & $5-7-94$ & 1148 & 12 & 30.7 & 7.02 & 9.4 & 0.1 \\
\hline S3 & -40 & $2-1-93$ & 1145 & 12 & 29.3 & 7.46 & 7.8 & 0.2 \\
\hline S3 & -40 & $8-16-93$ & 1026 & 15 & 29.1 & 7.33 & 8.9 & 0.1 \\
\hline
\end{tabular}


Table 2. Field data and concentrations of dissolved $\mathrm{H}_{2} \mathrm{~S}$ and $\mathrm{O}_{2}$ in ground-water, rain, seawater, and pond samples, Diego Garcia Atoll--Continued

[Samples from above sea level at well sites $\mathrm{S} 1, \mathrm{~S} 2$, and S5 collected from the unsaturated zone using lysimeters; ft, feet; gal, gallon; ${ }^{\circ} \mathrm{C}$, degrees Celsius; ppm, parts per million; --, not measured; n.a., not applicable]

\begin{tabular}{|c|c|c|c|c|c|c|c|c|}
\hline $\begin{array}{c}\text { Well site or } \\
\text { type of } \\
\text { sample }\end{array}$ & $\begin{array}{c}\text { Altitude } \\
\text { (ft) }\end{array}$ & Date & Time & Volume (gal) & $\begin{array}{c}\text { Temperature } \\
\left({ }^{\circ} \mathbf{C}\right)\end{array}$ & pH & $\begin{array}{c}\mathrm{H}_{2} \mathrm{~S} \\
(\mathrm{ppm})\end{array}$ & $\begin{array}{c}\mathrm{O}_{2} \\
(\mathrm{ppm})\end{array}$ \\
\hline S3 & -40 & $5-7-94$ & 1103 & 12 & 29.8 & 7.23 & 10.1 & 0.1 \\
\hline S4 & -11 & $1-30-93$ & 1745 & 9 & 30.6 & 7.34 & 3.6 & 0.1 \\
\hline S4 & -11 & $8-14-93$ & 1646 & 9 & 30.0 & 7.35 & 3.1 & 0.0 \\
\hline S4 & -11 & $5-7-94$ & 1019 & 12 & 30.4 & 7.35 & 2.8 & 0.1 \\
\hline S4 & -21 & $1-30-93$ & 1705 & 9 & 30.1 & 6.88 & 4.2 & 0.2 \\
\hline S4 & -21 & $8-14-93$ & 1602 & 11 & 30.0 & 7.10 & 3.8 & 0.0 \\
\hline S4 & -21 & $5-7-94$ & 941 & 9 & 30.1 & 7.18 & 3.4 & 0.1 \\
\hline S4 & -31 & $1-30-93$ & 1600 & 10 & 29.5 & 7.21 & 8.2 & 0.2 \\
\hline S4 & -31 & $8-14-93$ & 1450 & 9 & 28.9 & 7.31 & 6.5 & 0.1 \\
\hline S4 & -31 & $5-7-94$ & 907 & 12 & 29.4 & 7.33 & 5.2 & 0.1 \\
\hline S4 & -41 & $1-30-93$ & 1520 & 8 & 28.9 & 7.50 & 10.2 & 0.1 \\
\hline S4 & -41 & $8-14-93$ & 1340 & 9 & 28.5 & 7.40 & 7.7 & 0.1 \\
\hline S4 & -41 & $5-7-94$ & 825 & 12 & 28.9 & 7.48 & 8.6 & 0.1 \\
\hline S5 & 4 & $2-2-93$ & 1520 & 0.2 & 31.3 & 7.00 & -- & -- \\
\hline S5 & 4 & $8-21-93$ & 1518 & 0.2 & 28.7 & 7.47 & -- & -- \\
\hline S5 & 4 & $5-15-94$ & 1555 & 0.2 & 29.4 & 7.44 & -- & -- \\
\hline S5 & 3 & $2-2-93$ & 1535 & 0.2 & 30.6 & 6.91 & -- & -- \\
\hline S5 & 3 & $8-21-93$ & 1529 & 0.2 & 28.2 & 7.47 & $\ldots$ & -- \\
\hline S5 & 3 & $5-15-94$ & 1515 & 0.3 & 30.9 & 7.34 & -- & -- \\
\hline S5 & -12 & $1-31-93$ & 1315 & 12 & 27.5 & 7.36 & 1.0 & 0.1 \\
\hline S5 & -12 & $8-15-93$ & 1325 & 12 & 27.4 & 7.46 & 0.9 & 0.1 \\
\hline S5 & -12 & 5-6-94 & 1617 & 12 & 28.1 & 7.44 & 0.7 & 0.1 \\
\hline S5 & -18 & $1-31-93$ & 1215 & 12 & 27.8 & 7.16 & 1.1 & 0.1 \\
\hline S5 & -18 & $8-15-93$ & 1242 & 12 & 27.5 & 7.25 & 1.3 & 0.1 \\
\hline S5 & -18 & $5-6-94$ & 1435 & 12 & 28.0 & 7.22 & 1.1 & 0.1 \\
\hline S5 & -27 & $1-31-93$ & 1100 & 12 & 28.0 & 7.34 & 2.4 & 0.2 \\
\hline S5 & -27 & $8-15-93$ & 1130 & 12 & 27.4 & 7.39 & 2.2 & 0.1 \\
\hline S5 & -27 & $5-6-94$ & 1456 & 10 & 28.0 & 7.39 & 2.2 & 0.1 \\
\hline S5 & -37 & $1-31-93$ & 1000 & 10 & 27.7 & 7.41 & 1.3 & 0.1 \\
\hline S5 & -37 & $8-15-93$ & 1044 & 10 & 27.2 & 7.41 & 1.2 & 0.1 \\
\hline S5 & -37 & 5-6-94 & 1408 & 10 & 28.3 & 7.40 & 1.4 & 0.1 \\
\hline S5 & -46 & $1-31-93$ & 900 & 10 & 27.4 & 7.48 & 1.3 & 0.2 \\
\hline S5 & -46 & $8-15-93$ & 946 & 12 & 27.0 & 7.42 & 0.9 & 0.1 \\
\hline S5 & -46 & $5-6-94$ & 1317 & 10 & 28.3 & 7.40 & 1.2 & 0.1 \\
\hline BW21 & -8 & $2-3-93$ & 1420 & 60 & 27.6 & 7.41 & 0.3 & 0.2 \\
\hline BW21 & -8 & $8-21-93$ & 1032 & 60 & 27.6 & 7.39 & 0.2 & 0.9 \\
\hline BW21 & -8 & $5-9-94$ & 1101 & 12 & 29.5 & 7.40 & 0.1 & 0.4 \\
\hline BW21 & -23 & $2-3-93$ & 1400 & 60 & 27.7 & 7.49 & 0.4 & 0.2 \\
\hline BW21 & -23 & $8-21-93$ & 1126 & 70 & 27.8 & 7.44 & 0.3 & 0.6 \\
\hline BW21 & -23 & $5-9-94$ & 1112 & 24 & 28.9 & 7.50 & 0.3 & 0.3 \\
\hline BW21 & -48 & $2-3-93$ & 1320 & 60 & 27.4 & 7.82 & 1.3 & 0.2 \\
\hline BW21 & -48 & $8-21-93$ & 1218 & 84 & 27.5 & 7.78 & 1.3 & 0.6 \\
\hline BW21 & -48 & $5-9-94$ & 1117 & 36 & 28.4 & 7.82 & 1.3 & 0.2 \\
\hline
\end{tabular}


Table 2. Field data and concentrations of dissolved $\mathrm{H}_{2} \mathrm{~S}$ and $\mathrm{O}_{2}$ in ground-water, rain, seawater, and pond samples, Diego Garcia Atoll--Continued

[Samples from above sea level at well sites S1, S2, and S5 collected from the unsaturated zone using lysimeters; ft, feet; gal, gallon; ${ }^{\circ} \mathrm{C}$, degrees Celsius; ppm, parts per million; --, not measured; n.a., not applicable]

\begin{tabular}{|c|c|c|c|c|c|c|c|c|}
\hline $\begin{array}{l}\text { Well site or } \\
\text { type of } \\
\text { sample }\end{array}$ & $\begin{array}{c}\text { Altitude } \\
\text { (ft) }\end{array}$ & Date & Time & Volume (gal) & $\begin{array}{c}\text { Temperature } \\
\left({ }^{\circ} \mathbf{C}\right)\end{array}$ & $\mathrm{pH}$ & $\begin{array}{c}\mathrm{H}_{2} \mathrm{~S} \\
(\mathrm{ppm})\end{array}$ & $\begin{array}{c}\mathrm{O}_{2} \\
\text { (ppm) }\end{array}$ \\
\hline Rain & n.a. & $2-4-93$ & 740 & -- & 25.4 & 6.44 & 0.0 & 5.7 \\
\hline Rain & n.a. & $2-4-93$ & 1705 & -- & 29.4 & 6.87 & 0.0 & 5.4 \\
\hline Seawater & n.a. & $2-3-93$ & 950 & -- & 27.5 & 8.16 & 0.0 & 2.8 \\
\hline Seawater & n.a. & $2-7-93$ & 1700 & -- & 28.9 & 8.18 & 0.1 & 4.2 \\
\hline Seawater & n.a. & $8-22-93$ & 1000 & -- & 26.7 & 8.20 & 0.0 & 4.5 \\
\hline Seawater & n.a. & $8-22-93$ & 1056 & -- & 27.1 & 8.19 & 0.0 & 4.4 \\
\hline Seawater & n.a. & $5-9-94$ & 1630 & -- & 29.0 & 8.25 & 0.0 & 4.4 \\
\hline Pond & n.a. & $2-3-93$ & 910 & -- & 29.8 & 9.15 & 0.1 & 5.4 \\
\hline Pond & n.a. & $8-20-93$ & 1521 & -- & 27.6 & 8.86 & 0.0 & 6.1 \\
\hline Pond & n.a. & $5-9-94$ & 1800 & -- & 29.1 & 9.23 & 0.0 & 7.4 \\
\hline
\end{tabular}


Table 4. Concentrations of major dissolved ions in ground-water, rain, seawater, and pond samples, Diego Garcia Atoll [ft, feet; mg/L, milligrams per liter; meq/L, milliequivalents per liter; TA, titration alkalinity; n.a., not applicable]

\begin{tabular}{|c|c|c|c|c|c|c|c|c|c|c|}
\hline $\begin{array}{c}\text { Well site } \\
\text { or type of } \\
\text { sample }\end{array}$ & $\begin{array}{l}\text { Altitude } \\
\text { (ft) }\end{array}$ & Date & $\begin{array}{c}\mathrm{Ca}^{2+} \\
\text { (mg/L) }\end{array}$ & $\begin{array}{c}\mathrm{Mg}^{2+} \\
(\mathrm{mg} / \mathrm{L})\end{array}$ & $\begin{array}{c}\mathrm{Sr}^{2+} \\
(\mathrm{mg} / \mathrm{L})\end{array}$ & $\begin{array}{c}\mathrm{Na}^{+} \\
(\mathrm{mg} / \mathrm{L})\end{array}$ & $\begin{array}{c}K^{+} \\
(m g / L)\end{array}$ & $\underset{(\mathrm{mg} / \mathrm{L})}{\mathrm{Cl}^{-}}$ & $\begin{array}{l}\mathrm{SO}_{4}^{2-} \\
(\mathrm{mg} / \mathrm{L})\end{array}$ & $\begin{array}{c}\text { TA } \\
\text { (meq/L) }\end{array}$ \\
\hline S1 & 6 & $2-93$ & 123.0 & 40.8 & 2.74 & 18.5 & 1.4 & 2.6 & 4.5 & 8.48 \\
\hline S1 & 5 & $2-93$ & 128.0 & 48.7 & 2.75 & 22.3 & 1.0 & 3.1 & 2.0 & 10.38 \\
\hline S1 & 5 & $8-93$ & 147.0 & 64.2 & 2.84 & 35.4 & 2.4 & 32.4 & 6.2 & 11.23 \\
\hline S1 & 5 & $5-94$ & 168.0 & 72.3 & 2.82 & 15.4 & 0.7 & 7.6 & 9.8 & 13.75 \\
\hline S1 & -9 & $1-93$ & 112.0 & 102.0 & 2.47 & 21.8 & 1.4 & 16.6 & 1.0 & 14.43 \\
\hline S1 & -9 & $8-93$ & 114.3 & 99.0 & 2.55 & 18.8 & 0.9 & 9.6 & 0.8 & 14.16 \\
\hline S1 & -9 & $5-94$ & 136.0 & 108.0 & 2.81 & 20.3 & 0.5 & 10.4 & 0.9 & 16.33 \\
\hline $\mathrm{S} 1$ & -20 & $1-93$ & 56.4 & 69.8 & 2.29 & 15.7 & 1.1 & 9.8 & 4.1 & 8.70 \\
\hline S1 & -20 & $8-93$ & 52.2 & 79.0 & 2.21 & 21.7 & 1.3 & 10.1 & 1.9 & 9.55 \\
\hline S1 & -20 & $5-94$ & 82.8 & 109.0 & 3.54 & 20.8 & 1.2 & 9.6 & 1.0 & 13.69 \\
\hline S1 & -31 & $1-93$ & 37.9 & 62.9 & 1.89 & 21.4 & 1.6 & 14.8 & 14.7 & 7.11 \\
\hline S1 & -31 & 8-93 & 35.7 & 62.6 & 1.74 & 21.5 & 1.7 & 11.7 & 12.7 & 7.08 \\
\hline S1 & -31 & $5-94$ & 47.8 & 86.2 & 2.48 & 23.5 & 1.6 & 10.9 & 6.7 & 9.81 \\
\hline S1 & -39 & $1-93$ & 29.7 & 54.5 & 1.58 & 24.6 & 1.7 & 17.4 & 27.4 & 6.25 \\
\hline S1 & -39 & $8-93$ & 31.2 & 60.9 & 1.61 & 27.0 & 1.8 & 16.2 & 25.9 & 6.78 \\
\hline $\mathrm{S} 1$ & -39 & $5-94$ & 36.0 & 74.2 & 1.91 & 24.6 & 1.8 & 10.7 & 20.1 & 7.72 \\
\hline S2 & 7 & $2-93$ & 58.3 & 38.6 & 0.97 & 39.2 & 0.8 & 4.7 & 11.0 & 7.48 \\
\hline $\mathbf{S 2}$ & 7 & $8-93$ & 47.7 & 40.0 & 0.68 & 41.5 & 0.6 & 15.6 & 9.2 & 7.03 \\
\hline S2 & 7 & $5-94$ & 47.4 & 28.6 & 0.81 & 19.8 & 0.1 & 9.3 & 6.4 & 5.25 \\
\hline $\mathrm{S} 2$ & 6 & $2-93$ & 95.7 & 43.7 & 2.24 & 18.6 & 0.7 & 4.7 & 0.3 & 8.80 \\
\hline S2 & 6 & $8-93$ & 116.0 & 43.9 & 2.65 & 21.7 & 1.1 & 26.7 & 4.6 & 10.22 \\
\hline S2 & 6 & $5-94$ & 145.0 & 66.7 & 2.50 & 14.5 & 0.6 & 9.3 & 13.4 & 13.08 \\
\hline $\mathrm{S} 2$ & -9 & $2-93$ & 142.0 & 99.9 & 3.04 & 16.4 & 1.2 & 11.4 & 0.8 & 15.31 \\
\hline S2 & -9 & $8-93$ & 116.9 & 108.7 & 2.86 & 17.3 & 1.6 & 8.9 & 0.8 & 15.08 \\
\hline S2 & -9 & $5-94$ & 140.0 & 111.0 & 3.15 & 17.2 & 1.3 & 7.9 & 0.8 & 16.74 \\
\hline S2 & -19 & $2-93$ & 108.0 & 99.9 & 3.74 & 15.8 & 2.6 & 11.2 & 0.9 & 13.71 \\
\hline $\mathrm{S} 2$ & -19 & $8-93$ & 95.3 & 101.6 & 3.52 & 16.3 & 3.2 & 7.4 & 0.6 & 13.66 \\
\hline S2 & -19 & $5-94$ & 110.0 & 110.0 & 3.78 & 15.8 & 3.0 & 7.3 & 0.6 & 14.93 \\
\hline S2 & -29 & $2-93$ & 81.1 & 107.0 & 4.98 & 19.1 & 1.5 & 11.1 & 2.7 & 13.62 \\
\hline S2 & -29 & $8-93$ & 85.1 & 123.9 & 5.17 & 17.9 & 2.0 & 8.6 & 1.5 & 14.66 \\
\hline S2 & -29 & 5-94 & 95.9 & 135.0 & 5.60 & 17.8 & 2.1 & 8.4 & 1.0 & 16.18 \\
\hline S3 & -11 & $2-93$ & 99.8 & 65.5 & 3.29 & 37.5 & 13.4 & 39.3 & 2.1 & 10.83 \\
\hline S3 & -11 & $8-93$ & 94.1 & 71.6 & 3.26 & 37.5 & 14.3 & 37.1 & 2.7 & 11.18 \\
\hline S3 & -11 & $5-94$ & 98.8 & 71.7 & 3.31 & 39.6 & 14.6 & 36.3 & 2.3 & 11.74 \\
\hline S3 & -21 & $2-93$ & 80.2 & 59.4 & 3.11 & 39.4 & 14.0 & 39.2 & 3.2 & 9.57 \\
\hline S3 & -21 & $8-93$ & 79.9 & 64.4 & 3.21 & 42.4 & 14.7 & 38.9 & 2.2 & 10.10 \\
\hline S3 & -21 & $5-94$ & 89.0 & 69.3 & 3.28 & 41.4 & 14.9 & 38.7 & 2.2 & 10.67 \\
\hline S3 & -30 & $2-93$ & 69.8 & 59.5 & 3.19 & 40.7 & 12.8 & 41.6 & 4.6 & 9.15 \\
\hline S3 & -30 & $8-93$ & 76.7 & 67.4 & 3.14 & 43.3 & 14.4 & 41.5 & 1.7 & 10.06 \\
\hline S3 & -30 & $5-94$ & 78.8 & 71.9 & 3.40 & 42.3 & 14.3 & 41.4 & 2.4 & 10.66 \\
\hline S3 & -40 & $2-93$ & 42.1 & 66.8 & 1.88 & 44.8 & 11.3 & 54.6 & 12.6 & 7.89 \\
\hline S3 & -40 & $8-93$ & 45.7 & 70.6 & 2.24 & 44.6 & 12.6 & 46.3 & 10.3 & 8.56 \\
\hline S3 & -40 & $5-94$ & 54.1 & 78.9 & 2.65 & 45.5 & 13.1 & 46.2 & 6.8 & 9.62 \\
\hline
\end{tabular}


Table 4. Concentrations of major dissolved ions in ground-water, rain, seawater, and pond samples, Diego Garcia Atoll-Continued

\begin{tabular}{|c|c|c|c|c|c|c|c|c|c|c|}
\hline $\begin{array}{c}\text { Well site } \\
\text { or type of } \\
\text { sample }\end{array}$ & $\begin{array}{l}\text { Altitude } \\
\text { (ft) }\end{array}$ & Date & $\underset{(\mathrm{mg} / \mathrm{L})}{\mathrm{Ca}^{2+}}$ & $\begin{array}{c}\mathrm{Mg}^{2+} \\
(\mathrm{mg} / \mathrm{L})\end{array}$ & $\begin{array}{c}S r^{2+} \\
(\mathrm{mg} / \mathrm{L})\end{array}$ & $\begin{array}{c}\mathrm{Na}^{+} \\
(\mathrm{mg} / \mathrm{L})\end{array}$ & $\begin{array}{c}\mathrm{K}^{+} \\
(\mathbf{m g} / \mathrm{L})\end{array}$ & $\underset{(\mathrm{mg} / \mathrm{L})}{\mathrm{Cl}^{-}}$ & $\begin{array}{l}\mathrm{SO}_{4}^{2-} \\
(\mathrm{mg} / \mathrm{L})\end{array}$ & $\begin{array}{c}\text { TA } \\
\text { (meq/L) }\end{array}$ \\
\hline S4 & -11 & $1-93$ & 60.6 & 27.2 & 0.78 & 15.4 & 12.8 & 15.2 & 1.2 & 5.63 \\
\hline S4 & -11 & $8-93$ & 59.4 & 27.1 & 0.75 & 15.0 & 12.6 & 11.0 & 1.1 & 5.74 \\
\hline S4 & -11 & $5-94$ & 59.8 & 24.7 & 0.74 & 12.6 & 11.8 & 9.1 & 1.1 & 5.48 \\
\hline S4 & -21 & $1-93$ & 88.7 & 37.1 & 1.33 & 19.6 & 13.6 & 10.9 & 2.6 & 8.04 \\
\hline S4 & -21 & $8-93$ & 85.3 & 35.5 & 1.25 & 19.4 & 13.6 & 13.9 & 0.9 & 7.79 \\
\hline S4 & -21 & $5-94$ & 80.0 & 32.9 & 1.18 & 16.4 & 12.5 & 11.5 & 0.8 & 7.11 \\
\hline S4 & -31 & $1-93$ & 47.5 & 50.0 & 2.91 & 26.5 & 10.5 & 21.7 & 2.2 & 7.59 \\
\hline S4 & -31 & 8.93 & 48.9 & 51.6 & 2.63 & 22.7 & 12.1 & 15.8 & 1.4 & 7.44 \\
\hline S4 & -31 & $5-94$ & 51.0 & 49.0 & 2.80 & 19.5 & 12.5 & 12.9 & 0.8 & 6.96 \\
\hline S4 & -41 & $1-93$ & 37.9 & 67.7 & 4.60 & 37.0 & 6.4 & 36.8 & 4.3 & 8.07 \\
\hline S4 & -41 & $8-93$ & 36.7 & 68.4 & 4.55 & 33.5 & 8.2 & 30.8 & 2.9 & 7.95 \\
\hline S4 & -41 & $5-94$ & 35.9 & 63.8 & 4.55 & 29.1 & 10.6 & 21.4 & 1.6 & 7.52 \\
\hline S5 & 4 & $2-93$ & 74.6 & 13.9 & 0.79 & 61.1 & 1.9 & 7.5 & 9.0 & 7.11 \\
\hline S5 & 4 & $8-93$ & 100.2 & 27.2 & 0.90 & 21.5 & 1.7 & 9.0 & 10.0 & 7.93 \\
\hline S5 & 4 & $5-94$ & 122.0 & 24.7 & 1.13 & 14.4 & 0.2 & 4.3 & 3.5 & 8.03 \\
\hline S5 & 3 & $2-93$ & 80.8 & 18.1 & 0.84 & 16.6 & 2.0 & 6.4 & 3.8 & 5.86 \\
\hline S5 & 3 & $8-93$ & 88.9 & 38.9 & 0.90 & 6.9 & 0.2 & 6.0 & 5.4 & 7.62 \\
\hline S5 & 3 & $5-94$ & 110.0 & 25.1 & 0.87 & 3.4 & 0.2 & 3.4 & 3.6 & 7.33 \\
\hline S5 & -12 & $1-93$ & 69.6 & 13.3 & 1.21 & 6.2 & 2.5 & 7.5 & 1.6 & 4.54 \\
\hline S5 & -12 & $8-93$ & 66.0 & 13.1 & 1.08 & 5.0 & 2.2 & 6.0 & 2.0 & 4.36 \\
\hline S5 & -12 & $5-94$ & 68.9 & 11.9 & 1.10 & 4.8 & 1.7 & 5.3 & 1.8 & 4.42 \\
\hline S5 & -18 & $1-93$ & 74.2 & 25.6 & 1.86 & 6.1 & 1.7 & 8.6 & 3.1 & 5.62 \\
\hline S5 & -18 & 8.93 & 74.0 & 25.7 & 1.82 & 7.1 & 1.9 & 7.6 & 3.1 & 5.95 \\
\hline S5 & -18 & $5-94$ & 82.5 & 26.2 & 1.94 & 6.3 & 1.6 & 7.1 & 3.4 & 6.01 \\
\hline S5 & -27 & $1-93$ & 59.6 & 38.5 & 3.24 & 8.6 & 1.6 & 9.5 & 5.4 & 5.98 \\
\hline S5 & -27 & $8-93$ & 57.2 & 38.0 & 2.95 & 9.2 & 1.9 & 8.7 & 4.0 & 5.98 \\
\hline S5 & -27 & $5-94$ & 59.4 & 36.4 & 2.99 & 8.0 & 1.9 & 7.7 & 2.6 & 5.84 \\
\hline S5 & -37 & $1-93$ & 59.3 & 24.6 & 3.14 & 5.9 & 2.1 & 7.2 & 1.7 & 5.28 \\
\hline S5 & -37 & $8-93$ & 61.9 & 26.1 & 2.95 & 6.6 & 2.4 & 7.6 & 1.5 & 5.40 \\
\hline S5 & -37 & $5-94$ & 63.5 & 24.7 & 3.01 & 6.4 & 2.4 & 6.2 & 2.0 & 5.31 \\
\hline S5 & -46 & $1-93$ & 60.8 & 26.8 & 3.93 & 6.5 & 2.3 & 7.7 & 3.0 & 5.17 \\
\hline S5 & -46 & $8-93$ & 58.0 & 24.0 & 3.76 & 6.7 & 2.9 & 6.9 & 3.0 & 5.04 \\
\hline S5 & -46 & $5-94$ & 62.5 & 24.7 & 3.58 & 8.1 & 3.0 & 7.4 & 2.9 & 5.24 \\
\hline BW21 & -8 & $2-93$ & 69.1 & 17.6 & 1.47 & 7.2 & 1.1 & 9.5 & 6.2 & 4.79 \\
\hline BW21 & -8 & $8-93$ & 69.1 & 16.9 & 1.46 & 8.7 & 1.2 & 10.7 & 6.4 & 4.79 \\
\hline BW21 & -8 & $5-94$ & 73.4 & 16.9 & 1.41 & 8.5 & 1.5 & 10.5 & 7.3 & 4.87 \\
\hline BW21 & -23 & $2-93$ & 59.6 & 24.3 & 1.69 & 7.4 & 1.1 & 9.1 & 7.0 & 4.83 \\
\hline BW21 & -23 & $8-93$ & 64.3 & 21.2 & 1.66 & 8.1 & 1.2 & 9.8 & 7.3 & 4.83 \\
\hline BW21 & -23 & $5-94$ & 62.4 & 22.8 & 1.68 & 8.4 & 1.3 & 9.7 & 7.2 & 4.87 \\
\hline BW21 & -48 & $2-93$ & 26.2 & 47.7 & 1.41 & 26.4 & 2.2 & 29.7 & 27.9 & 5.03 \\
\hline BW21 & -48 & $8-93$ & 27.0 & 49.2 & 1.57 & 32.2 & 2.4 & 38.3 & 25.1 & 4.92 \\
\hline BW21 & -48 & $5-94$ & 25.4 & 46.0 & 1.41 & 23.6 & 2.1 & 31.3 & 23.8 & 4.84 \\
\hline Rain & n.a. & $2-93$ & 0.32 & 0.04 & 0.01 & 0.42 & 0.12 & 0.05 & 0.50 & 0.00 \\
\hline Rain & n.a. & $2-93$ & 0.35 & 0.12 & 0.00 & 1.03 & 0.14 & 0.05 & 0.51 & 0.02 \\
\hline
\end{tabular}


Table 4. Concentrations of major dissolved ions in ground-water, rain, seawater, and pond samples, Diego Garcia Atoll-Continued

\begin{tabular}{|c|c|c|c|c|c|c|c|c|c|c|}
\hline $\begin{array}{l}\text { Well site } \\
\text { or type of } \\
\text { sample }\end{array}$ & $\begin{array}{l}\text { Altitude } \\
\text { (ft) }\end{array}$ & Date & $\begin{array}{c}\mathrm{Ca}^{2+} \\
(\mathrm{mg} / \mathrm{L})\end{array}$ & $\begin{array}{c}\mathrm{Mg}^{2+} \\
(\mathrm{mg} / \mathrm{L})\end{array}$ & $\begin{array}{c}S r^{2+} \\
(m g / L)\end{array}$ & $\begin{array}{c}\mathrm{Na}^{+} \\
(\mathrm{mg} / \mathrm{L})\end{array}$ & $\begin{array}{c}K^{+} \\
(\mathrm{mg} / L)\end{array}$ & $\begin{array}{c}\mathrm{Cl}^{-} \\
(\mathrm{mg} / \mathrm{L})\end{array}$ & $\begin{array}{l}\mathrm{SO}_{4}{ }^{2-} \\
(\mathrm{mg} / \mathrm{L})\end{array}$ & $\begin{array}{c}\text { TA } \\
\text { (meq/L) }\end{array}$ \\
\hline Seawater & n.a. & $2-93$ & 404 & 1,263 & 6.00 & 10,913 & 410 & 19,040 & 2,675 & 2.31 \\
\hline Seawater & n.a. & $2-93$ & 392 & 1,230 & 6.97 & 10,438 & 405 & 18,110 & 2,586 & 2.59 \\
\hline Seawater & n.a. & $8-93$ & 425 & 1,318 & 7.92 & 11,280 & 408 & 19,271 & 2,705 & 2.35 \\
\hline Seawater & n.a. & $8-93$ & 420 & 1,298 & 7.84 & 11,260 & 410 & 19,379 & 2,724 & 2.27 \\
\hline Seawater & n.a. & $5-94$ & 402 & 1,267 & 7.29 & 11,610 & 397 & 21,212 & 2,806 & 2.24 \\
\hline Pond & n.a. & $2-93$ & 18.6 & 29.0 & 0.34 & 145.0 & 9.1 & 235.0 & 5.8 & 2.01 \\
\hline Pond & n.a. & 8.93 & 27.0 & 52.9 & 0.49 & 253.0 & 13.0 & 447.3 & 94.0 & 2.99 \\
\hline Pond & n.a. & $5-94$ & 26.3 & 59.3 & 0.44 & 354.0 & 15.8 & 634.5 & 10.0 & 2.13 \\
\hline
\end{tabular}


Table 5. Concentrations of dissolved inorganic and organic nutrients in ground-water, rain, seawater, and pond samples, Diego Garcia Atoll

[ft, feet; $\mu \mathrm{g} / \mathrm{L}$, micrograms per liter; mg/L, milligrams per liter; DOP, dissolved organic phosphorus; DON, dissolved organic nitrogen; DOC, dissolved organic carbon; n.a., not applicable]

\begin{tabular}{|c|c|c|c|c|c|c|c|c|c|}
\hline $\begin{array}{l}\text { Well site or } \\
\text { type of } \\
\text { sample }\end{array}$ & $\begin{array}{c}\text { Altitude } \\
\text { (ft) }\end{array}$ & Date & $\begin{array}{l}\mathbf{P O}_{4}^{-3} \\
\left(\mu g^{\prime} L\right)\end{array}$ & $\begin{array}{c}\mathrm{NO}_{3}^{-} \\
\left(\mu \mathrm{g}^{\prime} \mathrm{L}\right)\end{array}$ & $\underset{(\mu \mathrm{g} / L)}{\mathrm{NH}_{4}^{+}}$ & $\underset{(\mu \mathrm{g} / \mathrm{L})}{\mathrm{Si}(\mathrm{OH})_{4}}$ & $\begin{array}{c}\text { DOP } \\
(\mu \mathrm{g} / \mathrm{L})\end{array}$ & $\begin{array}{c}\text { DON } \\
(\mu g / L)\end{array}$ & $\begin{array}{c}\mathrm{DOC} \\
(\mathrm{mg} / \mathrm{L})\end{array}$ \\
\hline S1 & 6 & $2-93$ & 1.2 & 2.0 & 3,290 & 1,640 & 9.9 & 430 & 15.2 \\
\hline S1 & 5 & $2-93$ & 0.3 & 0.8 & 2,670 & 674 & 3.7 & 116 & 2.8 \\
\hline S1 & 5 & $8-93$ & 0 & 3.4 & 2,150 & 2,050 & 13.6 & 621 & 5.5 \\
\hline S1 & 5 & $5-94$ & 0 & 2.8 & 1,270 & 1,310 & 11.1 & 376 & 4.4 \\
\hline S1 & -9 & $1-93$ & 15.8 & 0.4 & 440 & 2,070 & 0.3 & 328 & 13.9 \\
\hline S1 & -9 & $8-93$ & 27.3 & 2.2 & 569 & 937 & 12.4 & 298 & 7.6 \\
\hline S1 & -9 & $5-94$ & 14.9 & 3.4 & 87.0 & 892 & 0 & 370 & 5.9 \\
\hline S1 & -20 & $1-93$ & 12.7 & 0.8 & 1,390 & 643 & 0.9 & 132 & 6.8 \\
\hline S1 & -20 & $8-93$ & 29.7 & 7.8 & 1,090 & 816 & 13.6 & 175 & 8.0 \\
\hline S1 & -20 & $5-94$ & 24.8 & 3.9 & 1,160 & 912 & 0 & 226 & 8.3 \\
\hline S1 & -31 & $1-93$ & 11.5 & 0.8 & 990 & 584 & 2.2 & 129 & 5.9 \\
\hline S1 & -31 & $8-93$ & 16.1 & 6.2 & 982 & 531 & 7.4 & 122 & 5.7 \\
\hline S1 & -31 & $5-94$ & 18.6 & 4.2 & 928 & 764 & 5.0 & 203 & 5.0 \\
\hline S1 & -39 & $1-93$ & 11.8 & 0.7 & 537 & 542 & 3.4 & 166 & 4.1 \\
\hline S1 & -39 & $8-93$ & 11.8 & 6.7 & 656 & 515 & 6.2 & 104 & 3.7 \\
\hline $\mathrm{S} 1$ & -39 & $5-94$ & 14.9 & 4.5 & 900 & 720 & 6.2 & 338 & 3.4 \\
\hline S2 & 7 & $2-93$ & 5.9 & 1,345 & 9.0 & 836 & 1.9 & 45.0 & 1.4 \\
\hline S2 & 7 & $8-93$ & 2.5 & 141 & 11.0 & 1,000 & 0 & 127 & 1.6 \\
\hline S2 & 7 & $5-94$ & 1.2 & 7.3 & 31.0 & 578 & 8.7 & 318 & 1.3 \\
\hline$S 2$ & 6 & $2-93$ & 0.3 & 7.3 & 1,730 & 1,110 & 2.8 & 189 & 7.9 \\
\hline S2 & 6 & $8-93$ & 0 & 1.1 & 6,020 & 1,910 & 9.9 & 320 & 6.1 \\
\hline S2 & 6 & $5-94$ & 0 & 2.8 & 5,220 & 1,180 & 8.7 & 436 & 8.7 \\
\hline S2 & -9 & $2-93$ & 16.1 & 6.4 & 434 & 1,350 & 0 & 112 & 10.9 \\
\hline S2 & -9 & $8-93$ & 35.9 & 1.1 & 744 & 1,340 & 0 & 337 & 8.5 \\
\hline S2 & -9 & $5-94$ & 19.8 & 2.8 & 239 & 1,270 & 6.2 & 436 & 8.9 \\
\hline S2 & -19 & $2-93$ & 14.9 & 1.1 & 1,300 & 1,670 & 1.9 & 182 & 8.3 \\
\hline S2 & -19 & $8-93$ & 29.7 & 1.1 & 832 & 1,750 & 0 & 189 & 6.3 \\
\hline S2 & -19 & $5-94$ & 22.3 & 2.2 & 310 & 1,380 & 8.7 & 205 & 5.7 \\
\hline S2 & -29 & $2-93$ & 15.5 & 0.3 & 1,030 & 1,050 & 1.5 & 295 & 11.6 \\
\hline S2 & -29 & $8-93$ & 23.5 & 1.1 & 860 & 1,240 & 3.7 & 180 & 8.4 \\
\hline S2 & -29 & 5.94 & 27.3 & 2.8 & 363 & 1,430 & 8.7 & 178 & 6.9 \\
\hline S3 & -11 & $2-93$ & 35.6 & 0.8 & 472 & 2,200 & 2.8 & 537 & 17.6 \\
\hline S3 & -11 & $8-93$ & 50.8 & 2.8 & 698 & 2,260 & 1.2 & 245 & 15.4 \\
\hline S3 & -11 & $5-94$ & 35.9 & 3.4 & 590 & 2,210 & 8.7 & 225 & 13.0 \\
\hline S3 & -21 & $2-93$ & 18.0 & 0.6 & 375 & 1,860 & 2.8 & 279 & 11.0 \\
\hline S3 & -21 & $8-93$ & 28.5 & 5.0 & 502 & 2,190 & 2.5 & 186 & 11.3 \\
\hline S3 & -21 & $5-94$ & 21.1 & 2.8 & 447 & 2,180 & 8.7 & 160 & 9.4 \\
\hline S3 & -30 & $2-93$ & 18.0 & 0.3 & 388 & 1,960 & 1.9 & 146 & 9.9 \\
\hline S3 & -30 & $8-93$ & 18.6 & 6.7 & 487 & 2,160 & 7.4 & 183 & 11.2 \\
\hline S3 & -30 & $5-94$ & 13.6 & 2.8 & 488 & 2,200 & 6.2 & 177 & 9.7 \\
\hline S3 & -40 & $2-93$ & 14.6 & 0.1 & 287 & 1,700 & 2.5 & 72 & 4.6 \\
\hline S3 & -40 & $8-93$ & 16.1 & 6.2 & 356 & 1,890 & 5.0 & 123 & 7.0 \\
\hline S3 & -40 & $5-94$ & 14.9 & 3.4 & 411 & 2,150 & 6.2 & 150 & 7.4 \\
\hline
\end{tabular}


Table 5. Concentrations of dissolved inorganic and organic nutrients in ground-water, rain, seawater, and pond samples, Diego Garcia Atoll--Continued

[ft, feet; $\mu \mathrm{g} / \mathrm{L}$, micrograms per liter; $\mathrm{mg} / \mathrm{L}$, milligrams per liter; DOP, dissolved organic phosphorus; DON, dissolved organic nitrogen; DOC, dissolved organic carbon; n.a., not applicable]

\begin{tabular}{|c|c|c|c|c|c|c|c|c|c|}
\hline $\begin{array}{c}\text { Well site or } \\
\text { type of } \\
\text { sample } \\
\end{array}$ & $\begin{array}{c}\text { Altitude } \\
\text { (ft) }\end{array}$ & Date & $\begin{array}{l}\mathrm{PO}^{-3} \\
\left(\mu g^{\prime} L\right)\end{array}$ & $\begin{array}{c}\mathrm{NO}_{3}^{-} \\
(\mu \mathrm{g} / \mathrm{L})\end{array}$ & $\begin{array}{c}\mathrm{NH}_{4}^{+} \\
\left(\mu \mathrm{g}^{\prime}\right)\end{array}$ & $\begin{array}{c}\mathrm{Si}(\mathrm{OH})_{4} \\
(\mu \mathrm{g} / \mathrm{L})\end{array}$ & $\begin{array}{c}\text { DOP } \\
(\mu g / L)\end{array}$ & $\begin{array}{c}\text { DON } \\
(\mu g / L)\end{array}$ & $\begin{array}{c}\text { DOC } \\
\text { (mg/L) }\end{array}$ \\
\hline $\begin{array}{l}\text { S4 } \\
\text { S4 } \\
\text { S4 }\end{array}$ & $\begin{array}{l}-11 \\
-11 \\
-11\end{array}$ & $\begin{array}{l}1-93 \\
8-93 \\
5-94\end{array}$ & $\begin{array}{l}16.4 \\
21.1 \\
11.1\end{array}$ & $\begin{array}{l}0.1 \\
0.6 \\
2.8\end{array}$ & $\begin{array}{r}1,500 \\
1,280 \\
848\end{array}$ & $\begin{array}{r}1,060 \\
969 \\
893\end{array}$ & $\begin{array}{l}1.9 \\
5.0 \\
7.4\end{array}$ & $\begin{array}{r}45 \\
209 \\
214\end{array}$ & $\begin{array}{l}4.1 \\
4.5 \\
3.4\end{array}$ \\
\hline $\begin{array}{l}\text { S4 } \\
\text { S4 } \\
\text { S4 }\end{array}$ & $\begin{array}{l}-21 \\
-21 \\
-21\end{array}$ & $\begin{array}{l}1-93 \\
8-93 \\
5-94\end{array}$ & $\begin{array}{l}17.3 \\
23.5 \\
12.4\end{array}$ & $\begin{array}{l}0.1 \\
1.7 \\
2.8\end{array}$ & $\begin{array}{l}2,770 \\
3,000 \\
2,000\end{array}$ & $\begin{array}{l}1,600 \\
1,510 \\
1,210\end{array}$ & $\begin{array}{l}0.9 \\
5.0 \\
7.4\end{array}$ & $\begin{array}{r}70 \\
150 \\
148\end{array}$ & $\begin{array}{l}4.5 \\
4.9 \\
3.8\end{array}$ \\
\hline $\begin{array}{l}\text { S4 } \\
\text { S4 } \\
\text { S4 }\end{array}$ & $\begin{array}{l}-31 \\
-31 \\
-31\end{array}$ & $\begin{array}{l}1-93 \\
8-93 \\
5-94\end{array}$ & $\begin{array}{l}16.4 \\
14.9 \\
11.1\end{array}$ & $\begin{array}{l}0.1 \\
7.8 \\
2.2\end{array}$ & $\begin{array}{l}2,360 \\
2,540 \\
1,860\end{array}$ & $\begin{array}{l}2,070 \\
1,750 \\
1,380\end{array}$ & $\begin{array}{r}2.2 \\
12.4 \\
13.6\end{array}$ & $\begin{array}{c}56.0 \\
144 \\
83.0\end{array}$ & $\begin{array}{l}2.8 \\
3.2 \\
2.3\end{array}$ \\
\hline $\begin{array}{l}\text { S4 } \\
\text { S4 } \\
\text { S4 }\end{array}$ & $\begin{array}{l}-41 \\
-41 \\
-41\end{array}$ & $\begin{array}{l}1-93 \\
8-93 \\
5-94\end{array}$ & $\begin{array}{l}18.3 \\
18.6 \\
14.9\end{array}$ & $\begin{array}{l}0.4 \\
7.3 \\
2.8\end{array}$ & $\begin{array}{l}2,010 \\
2,180 \\
2,200\end{array}$ & $\begin{array}{l}2,410 \\
2,210 \\
2,050\end{array}$ & $\begin{array}{l}2.2 \\
3.7 \\
6.2\end{array}$ & $\begin{array}{c}64.0 \\
137 \\
79.0\end{array}$ & $\begin{array}{l}2.5 \\
2.9 \\
2.3\end{array}$ \\
\hline $\begin{array}{l}\text { S5 } \\
\text { S5 } \\
\text { S5 }\end{array}$ & $\begin{array}{l}4 \\
4 \\
4\end{array}$ & $\begin{array}{l}2-93 \\
8-93 \\
5-94\end{array}$ & $\begin{array}{l}7.4 \\
7.4 \\
5.0\end{array}$ & $\begin{array}{l}109 \\
1.1 \\
5.0\end{array}$ & $\begin{array}{r}3.0 \\
25.0 \\
36.0\end{array}$ & $\begin{array}{l}781 \\
608 \\
343\end{array}$ & $\begin{array}{r}2.5 \\
11.1 \\
8.7\end{array}$ & $\begin{array}{l}188 \\
168 \\
246\end{array}$ & $\begin{array}{l}2.1 \\
2.3 \\
2\end{array}$ \\
\hline $\begin{array}{l}\text { S5 } \\
\text { S5 } \\
\text { S5 }\end{array}$ & $\begin{array}{l}3 \\
3 \\
3\end{array}$ & $\begin{array}{l}2-93 \\
8-93 \\
5-94\end{array}$ & $\begin{array}{r}6.2 \\
9.9 \\
13.6\end{array}$ & $\begin{array}{r}72.0 \\
2.8 \\
3.9\end{array}$ & $\begin{array}{r}2.0 \\
7.0 \\
11.0\end{array}$ & $\begin{array}{l}335 \\
169 \\
229\end{array}$ & $\begin{array}{l}3.4 \\
6.2 \\
7.4\end{array}$ & $\begin{array}{l}177 \\
161 \\
256\end{array}$ & $\begin{array}{l}2.7 \\
2.6 \\
3.3\end{array}$ \\
\hline $\begin{array}{l}\text { S5 } \\
\text { S5 } \\
\text { S5 }\end{array}$ & $\begin{array}{l}-12 \\
-12 \\
-12\end{array}$ & $\begin{array}{l}1-93 \\
8-93 \\
5-94\end{array}$ & $\begin{array}{l}28.8 \\
39.6 \\
43.4\end{array}$ & $\begin{array}{l}0.6 \\
1.1 \\
1.7\end{array}$ & $\begin{array}{c}51.0 \\
104 \\
60\end{array}$ & $\begin{array}{l}479 \\
378 \\
387\end{array}$ & $\begin{array}{l}0 \\
9.9 \\
9.9\end{array}$ & $\begin{array}{l}168 \\
172 \\
218\end{array}$ & $\begin{array}{l}3.3 \\
3.4 \\
2.4\end{array}$ \\
\hline $\begin{array}{l}\text { S5 } \\
\text { S5 } \\
\text { S5 }\end{array}$ & $\begin{array}{l}-18 \\
-18 \\
-18\end{array}$ & $\begin{array}{l}1-93 \\
8-93 \\
5-94\end{array}$ & $\begin{array}{l}24.2 \\
24.8 \\
21.1\end{array}$ & $\begin{array}{l}0.3 \\
1.1 \\
1.1\end{array}$ & $\begin{array}{c}92.0 \\
125 \\
94\end{array}$ & $\begin{array}{l}387 \\
539 \\
442\end{array}$ & $\begin{array}{l}0.3 \\
5.0 \\
7.4\end{array}$ & $\begin{array}{l}153 \\
176 \\
195\end{array}$ & $\begin{array}{l}2.8 \\
3.1 \\
2.4\end{array}$ \\
\hline $\begin{array}{l}\text { S5 } \\
\text { S5 } \\
\text { S5 }\end{array}$ & $\begin{array}{l}-27 \\
-27 \\
-27\end{array}$ & $\begin{array}{l}1-93 \\
8-93 \\
5-94\end{array}$ & $\begin{array}{l}15.5 \\
19.8 \\
12.4\end{array}$ & $\begin{array}{l}0.3 \\
1.7 \\
1.1\end{array}$ & $\begin{array}{l}194 \\
250 \\
217\end{array}$ & $\begin{array}{l}498 \\
498 \\
528\end{array}$ & $\begin{array}{l}0.6 \\
8.7 \\
8.7\end{array}$ & $\begin{array}{l}115 \\
187 \\
201\end{array}$ & $\begin{array}{l}2.1 \\
2.6 \\
2.1\end{array}$ \\
\hline $\begin{array}{l}\text { S5 } \\
\text { S5 } \\
\text { S5 }\end{array}$ & $\begin{array}{l}-37 \\
-37 \\
-37\end{array}$ & $\begin{array}{l}1-93 \\
8-93 \\
5-94\end{array}$ & $\begin{array}{r}12.1 \\
18.6 \\
9.9\end{array}$ & $\begin{array}{l}0.1 \\
1.7 \\
0.6\end{array}$ & $\begin{array}{l}196 \\
227 \\
178\end{array}$ & $\begin{array}{l}502 \\
563 \\
496\end{array}$ & $\begin{array}{l}1.9 \\
1.2 \\
8.7\end{array}$ & $\begin{array}{l}94.0 \\
132 \\
183\end{array}$ & $\begin{array}{l}1.9 \\
2.5 \\
1.7\end{array}$ \\
\hline $\begin{array}{l}\text { S5 } \\
\text { S5 } \\
\text { S5 }\end{array}$ & $\begin{array}{l}-46 \\
-46 \\
-46\end{array}$ & $\begin{array}{l}1-93 \\
8-93 \\
5-94\end{array}$ & $\begin{array}{r}7.7 \\
11.1 \\
6.2\end{array}$ & $\begin{array}{l}0.3 \\
0.0 \\
0.0\end{array}$ & $\begin{array}{l}227 \\
167 \\
153\end{array}$ & $\begin{array}{l}524 \\
531 \\
631\end{array}$ & $\begin{array}{l}2.2 \\
3.7 \\
7.4\end{array}$ & $\begin{array}{c}86.0 \\
114 \\
161\end{array}$ & $\begin{array}{l}1.8 \\
2.2 \\
1.8\end{array}$ \\
\hline $\begin{array}{l}\text { BW21 } \\
\text { BW21 } \\
\text { BW21 }\end{array}$ & $\begin{array}{l}-8 \\
-8 \\
-8\end{array}$ & $\begin{array}{l}2-93 \\
8-93 \\
5-94\end{array}$ & $\begin{array}{l}16.4 \\
24.8 \\
18.6\end{array}$ & $\begin{array}{r}0.1 \\
0.0 \\
134\end{array}$ & $\begin{array}{r}13.0 \\
18.0 \\
6.0\end{array}$ & $\begin{array}{l}486 \\
596 \\
448\end{array}$ & $\begin{array}{l}3.7 \\
2.5 \\
6.2\end{array}$ & $\begin{array}{l}162 \\
170 \\
290\end{array}$ & $\begin{array}{l}2.1 \\
2.7 \\
2.4\end{array}$ \\
\hline $\begin{array}{l}\text { BW21 } \\
\text { BW21 } \\
\text { BW21 }\end{array}$ & $\begin{array}{l}-23 \\
-23 \\
-23\end{array}$ & $\begin{array}{l}2-93 \\
8-93 \\
5-94\end{array}$ & $\begin{array}{r}10.8 \\
8.7 \\
11.1\end{array}$ & $\begin{array}{l}1.3 \\
0.0 \\
2.8\end{array}$ & $\begin{array}{r}19.0 \\
21.0 \\
6.0\end{array}$ & $\begin{array}{l}461 \\
385 \\
484\end{array}$ & $\begin{array}{r}4.0 \\
5.0 \\
11.1\end{array}$ & $\begin{array}{l}159 \\
160 \\
262\end{array}$ & $\begin{array}{l}1.9 \\
2.4 \\
1.8\end{array}$ \\
\hline $\begin{array}{l}\text { BW21 } \\
\text { BW21 } \\
\text { BW21 }\end{array}$ & $\begin{array}{l}-48 \\
-48 \\
-48\end{array}$ & $\begin{array}{l}2-93 \\
8-93 \\
5-94\end{array}$ & $\begin{array}{l}8.1 \\
7.4 \\
7.4\end{array}$ & $\begin{array}{l}1.3 \\
2.2 \\
2.8\end{array}$ & $\begin{array}{l}148 \\
165 \\
110\end{array}$ & $\begin{array}{l}629 \\
549 \\
608\end{array}$ & $\begin{array}{r}3.4 \\
9.9 \\
11.1\end{array}$ & $\begin{array}{l}109 \\
101 \\
220\end{array}$ & $\begin{array}{l}1.3 \\
1.7 \\
1.2\end{array}$ \\
\hline Rain & n.a. & $2-93$ & 3.1 & 12.5 & 7.0 & 6.0 & 3.4 & 88 & 0.7 \\
\hline
\end{tabular}


Table 5. Concentrations of dissolved inorganic and organic nutrients in ground-water, rain, seawater, and pond samples, Diego Garcia Atoll--Continued

[ft, feet; $\mu \mathrm{g} / \mathrm{L}$, micrograms per liter; $\mathrm{mg} / \mathrm{L}$, milligrams per liter; DOP, dissolved organic phosphorus; DON, dissolved organic nitrogen; DOC, dissolved organic carbon; n.a., not applicable]

\begin{tabular}{|c|c|c|c|c|c|c|c|c|c|}
\hline $\begin{array}{l}\text { Well site or } \\
\text { type of } \\
\text { sample }\end{array}$ & $\begin{array}{l}\text { Altitude } \\
\text { (ft) }\end{array}$ & Date & $\begin{array}{l}\mathrm{PO}_{4}^{-3} \\
(\mu \mathrm{g} / L)\end{array}$ & $\underset{\left(\mu \mathrm{g}^{\prime}\left(\mathbf{L}^{-}\right)\right.}{\mathrm{NO}^{-}}$ & $\underset{\left(\mu \mathrm{g} / \mathbf{L}^{+}\right.}{\mathrm{NH}^{+}}$ & $\underset{(\mu \mathrm{g} / \mathrm{L})_{4}}{\mathrm{Si}(\mathrm{OH})_{4}}$ & $\begin{array}{c}\text { DOP } \\
(\mu g / L)\end{array}$ & $\begin{array}{c}\text { DON } \\
(\mu g / L)\end{array}$ & $\begin{array}{c}\mathrm{DOC} \\
(\mathrm{mg} / \mathrm{L})\end{array}$ \\
\hline Rain & n.a. & $2-93$ & 2.5 & 16.5 & 10.0 & 6.0 & 5.3 & 102 & 0.8 \\
\hline Seawater & n.a. & $2-93$ & 8.4 & 3.2 & 4.0 & 99.0 & 5.0 & 77.0 & 0.4 \\
\hline Seawater & n.a. & $2-93$ & 5.3 & 2.5 & 56.0 & 206 & 8.1 & 139 & 0.5 \\
\hline Seawater & n.a. & $8-93$ & 6.8 & 5.6 & 4.0 & 23.0 & 7.4 & 88.0 & 0.3 \\
\hline Seawater & n.a. & $8-93$ & 7.7 & 11.5 & 11.0 & 42.0 & 4.6 & 118 & 0.3 \\
\hline Seawater & n.a. & $5-94$ & 5.3 & 2.8 & 3.0 & 63 & 5.0 & 109 & 0.3 \\
\hline Pond & n.a. & $2-93$ & 0.6 & 0.4 & 44.0 & 389 & 5.9 & 312 & 4.9 \\
\hline Pond & n.a. & $8-93$ & 0.9 & 0.8 & 2.0 & 634 & 5.6 & 386 & 5.3 \\
\hline Pond & n.a. & $5-94$ & 1.1 & 0.6 & 28.0 & 397 & 2.3 & 357 & 5.8 \\
\hline
\end{tabular}


Table 10. Charge balance, saturation index with respect ot aragonite, and total dissolved inorganic carbon in groundwater samples, Diego Garcia Atoll

[Calculations done using WATEQ4F (Ball and Nordstrom, 1991)]

\begin{tabular}{|c|c|c|c|c|c|c|c|}
\hline \multirow[b]{2}{*}{$\begin{array}{l}\text { Well } \\
\text { site }\end{array}$} & \multirow[b]{2}{*}{$\begin{array}{c}\text { Altitude of } \\
\text { sample } \\
\text { (feet) }\end{array}$} & \multirow[b]{2}{*}{ Date } & \multirow[b]{2}{*}{$\begin{array}{c}\text { Charge } \\
\text { balance } \\
\text { (percent) }\end{array}$} & \multirow[b]{2}{*}{$\begin{array}{l}\text { Dissolved } \\
\text { inorganic } \\
\text { carbon } \\
\text { (mM) }\end{array}$} & \multirow[b]{2}{*}{$\begin{array}{l}\text { Saturation } \\
\text { index with } \\
\text { respect to } \\
\text { aragonite }\end{array}$} & \multicolumn{2}{|c|}{$\begin{array}{l}\text { Calculated contributions to } \\
\text { total dissolved inorganic } \\
\text { carbon from: }\end{array}$} \\
\hline & & & & & & $\begin{array}{c}\text { Carbonate } \\
\text { mineral } \\
\text { dissolution } \\
\text { (mM) }\end{array}$ & $\begin{array}{c}\text { Organic } \\
\text { respiration } \\
\text { (mM) }\end{array}$ \\
\hline S1 & 6 & $2-93$ & 20.6 & 9.6 & 0.33 & 4.8 & 4.8 \\
\hline S1 & 5 & $2-93$ & 10.3 & 11.5 & 0.49 & 5.2 & 6.3 \\
\hline S1 & 5 & $8-93$ & 16.2 & 12.9 & 0.43 & 6.3 & 6.6 \\
\hline S1 & 5 & 5-94 & 6.9 & 15.9 & 0.53 & 7.2 & 8.7 \\
\hline S1 & -9 & $1-93$ & 0.9 & 17.7 & 0.19 & 7.0 & 10.7 \\
\hline S1 & -9 & $8-93$ & 2.3 & 17.4 & 0.19 & 7.0 & 10.4 \\
\hline SI & -9 & $5-94$ & 0.0 & 21.2 & 0.19 & 7.9 & 13.3 \\
\hline S1 & -20 & $1-93$ & 3.8 & 9.3 & 0.19 & 4.3 & 5.0 \\
\hline S1 & -20 & $8-93$ & 3.3 & 10.2 & 0.10 & 4.6 & 5.6 \\
\hline S1 & -20 & 5-94 & 1.5 & 16.1 & 0.14 & 6.6 & 9.5 \\
\hline S1 & -31 & $1-93$ & 3.9 & 7.3 & 0.07 & 3.6 & 3.7 \\
\hline S1 & -31 & $8-93$ & 4.4 & 7.1 & 0.07 & 3.5 & 3.6 \\
\hline S1 & -31 & $5-94$ & 3.9 & 10.3 & 0.09 & 4.8 & 5.5 \\
\hline S1 & -39 & $1-93$ & -2.2 & 6.3 & 0.04 & 3.0 & 3.3 \\
\hline S1 & -39 & $8-93$ & 1.2 & 6.8 & 0.04 & 3.3 & 3.5 \\
\hline S1 & -39 & 5-94 & 7.7 & 7.8 & 0.21 & 4.0 & 3.8 \\
\hline S2 & 7 & $2-93$ & -1.3 & 8.6 & -0.04 & 3.1 & 5.5 \\
\hline S2 & 7 & $8-93$ & -2.2 & 8.9 & -0.40 & 2.8 & 6.0 \\
\hline S2 & 7 & $5-94$ & -0.8 & 5.3 & 0.57 & 2.4 & 2.9 \\
\hline S2 & 6 & $2-93$ & 4.8 & 9.9 & 0.28 & 4.2 & 5.7 \\
\hline S2 & 6 & $8-93$ & -1.8 & 11.6 & 0.35 & 4.7 & 6.9 \\
\hline S2 & 6 & $5-94$ & 1.4 & 15.5 & 0.39 & 6.4 & 9.1 \\
\hline S2 & -9 & $2-93$ & 3.2 & 19.6 & 0.22 & 7.7 & 11.9 \\
\hline S2 & -9 & $8-93$ & 2.2 & 17.4 & 0.37 & 7.4 & 10.0 \\
\hline S2 & -9 & $5-94$ & 0.1 & 22.2 & 0.18 & 8.1 & 14.1 \\
\hline S2 & -19 & $2-93$ & 3.5 & 16.7 & 0.18 & 6.8 & 9.9 \\
\hline S2 & -19 & $8-93$ & 1.2 & 16.6 & 0.14 & 6.6 & 10.0 \\
\hline S2 & -19 & $5-94$ & 1.7 & 18.8 & 0.14 & 7.3 & 11.5 \\
\hline S2 & -29 & $2-93$ & -0.6 & 16.0 & 0.13 & 6.5 & 9.5 \\
\hline S2 & -29 & $8-93$ & 3.4 & 17.5 & 0.13 & 7.3 & 10.2 \\
\hline S2 & -29 & $5-94$ & 2.6 & 20.1 & 0.12 & 8.0 & 12.1 \\
\hline S3 & -11 & $2-93$ & 3.9 & 12.8 & 0.12 & 5.2 & 7.6 \\
\hline S3 & -11 & $8-93$ & 3.4 & 12.9 & 0.16 & 5.3 & 7.6 \\
\hline S3 & -11 & $5-94$ & 1.8 & 14.1 & 0.12 & 5.5 & 8.6 \\
\hline S3 & -21 & $2-93$ & 3.0 & 10.5 & 0.14 & 4.5 & 6.0 \\
\hline S3 & -21 & $8-93$ & 3.2 & 11.2 & 0.14 & 4.7 & 6.5 \\
\hline S3 & -21 & $5-94$ & 5.2 & 12.2 & 0.14 & 5.1 & 7.1 \\
\hline S3 & -30 & $2-93$ & 1.5 & 9.9 & 0.08 & 4.2 & 5.7 \\
\hline S3 & -30 & $8-93$ & 4.1 & 11.0 & 0.14 & 4.7 & 6.3 \\
\hline S3 & -30 & $5-94$ & 2.4 & 12.0 & 0.11 & 5.0 & 7.0 \\
\hline S3 & -40 & $2-93$ & 2.1 & 7.9 & 0.13 & 3.8 & 4.1 \\
\hline S3 & -40 & $8-93$ & 3.4 & 8.8 & 0.08 & 4.1 & 4.7 \\
\hline S3 & -40 & $5-94$ & 4.7 & 10.1 & 0.08 & 4.6 & 5.5 \\
\hline
\end{tabular}


Table 10. Charge balance, saturation index with respect ot aragonite, and total dissolved inorganic carbon in groundwater samples, Diego Garcia Atoll--Continued

[Calculations done using WATEQ4F (Ball and Nordstrom, 1991)]

\begin{tabular}{|c|c|c|c|c|c|c|c|}
\hline \multirow[b]{2}{*}{$\begin{array}{l}\text { Well } \\
\text { site }\end{array}$} & \multirow[b]{2}{*}{$\begin{array}{c}\text { Altitude of } \\
\text { sample } \\
\text { (feet) }\end{array}$} & \multirow[b]{2}{*}{ Date } & \multirow[b]{2}{*}{$\begin{array}{c}\text { Charge } \\
\text { balance } \\
\text { (percent) }\end{array}$} & \multirow[b]{2}{*}{$\begin{array}{c}\text { Dissolved } \\
\text { inorganic } \\
\text { carbon } \\
\text { (mM) }\end{array}$} & \multirow[b]{2}{*}{$\begin{array}{l}\text { Saturation } \\
\text { index with } \\
\text { respect to } \\
\text { aragonite }\end{array}$} & \multicolumn{2}{|c|}{$\begin{array}{l}\text { Calculated contributions to } \\
\text { total dissolved inorganic } \\
\text { carbon from: }\end{array}$} \\
\hline & & & & & & $\begin{array}{c}\text { Carbonate } \\
\text { mineral } \\
\text { dissolution } \\
\text { (mM) }\end{array}$ & $\begin{array}{c}\text { Organic } \\
\text { respiration } \\
(\mathrm{mM})\end{array}$ \\
\hline S4 & -11 & $1-93$ & 4.9 & 5.9 & 0.10 & 2.6 & 3.3 \\
\hline S4 & -11 & $8-93$ & 3.2 & 6.0 & 0.14 & 2.6 & 3.4 \\
\hline S4 & -11 & $5-94$ & 3.1 & 5.8 & 0.10 & 2.5 & 3.3 \\
\hline S4 & -21 & $1-93$ & 5.9 & 9.8 & -0.07 & 3.8 & 6.1 \\
\hline S4 & -21 & 8-93 & 4.9 & 8.7 & 0.15 & 3.6 & 5.1 \\
\hline S4 & -21 & $5-94$ & 5.9 & 7.8 & 0.14 & 3.4 & 4.4 \\
\hline S4 & -31 & $1-93$ & -1.3 & 8.0 & -0.05 & 3.3 & 4.8 \\
\hline S4 & -31 & $8-93$ & 3.9 & 7.7 & 0.07 & 3.4 & 4.3 \\
\hline S4 & -31 & $5-94$ & 7.9 & 7.3 & 0.07 & 3.3 & 4.0 \\
\hline S4 & -41 & $1-93$ & 3.1 & 8.0 & 0.13 & 3.8 & 4.2 \\
\hline S4 & -41 & $8-93$ & 5.5 & 8.1 & 0.05 & 3.8 & 4.3 \\
\hline S4 & -41 & $5-94$ & 8.0 & 7.5 & 0.07 & 3.6 & 3.9 \\
\hline S5 & 4 & 2.93 & 1.0 & 8.4 & -0.04 & 2.4 & 6.0 \\
\hline S5 & 4 & $8-93$ & -1.9 & 8.4 & 0.55 & 3.6 & 4.8 \\
\hline S5 & 4 & $5-94$ & 6.5 & 8.5 & 0.61 & 4.1 & 4.4 \\
\hline S5 & 3 & $2-93$ & 3.0 & 7.2 & -0.17 & 2.8 & 4.4 \\
\hline S5 & 3 & $8-93$ & 0.7 & 8.1 & 0.47 & 3.8 & 4.2 \\
\hline S5 & 3 & $5-94$ & 2.9 & 7.9 & 0.46 & 3.8 & 4.1 \\
\hline S5 & -11 & $1-93$ & 3.1 & 4.9 & 0.08 & 2.3 & 2.6 \\
\hline S5 & -11 & $8-93$ & 2.4 & 4.6 & 0.15 & 2.2 & 2.4 \\
\hline S5 & -11 & $5-94$ & 1.9 & 4.7 & 0.16 & 2.2 & 2.4 \\
\hline S5 & -18 & $1-93$ & 3.9 & 6.3 & -0.02 & 2.9 & 3.4 \\
\hline S5 & -18 & $8-93$ & -0.3 & 6.5 & 0.10 & 2.9 & 3.6 \\
\hline S5 & -18 & $5-94$ & 5.6 & 6.6 & 0.11 & 3.2 & 3.5 \\
\hline S5 & -27 & $1-93$ & 4.5 & 6.4 & 0.08 & 3.1 & 3.2 \\
\hline S5 & -27 & $8-93$ & 3.3 & 6.3 & 0.12 & 3.0 & 3.3 \\
\hline S5 & -27 & $5-94$ & 5.2 & 6.2 & 0.13 & 3.0 & 3.1 \\
\hline S5 & -37 & $1-93$ & -2.5 & 5.6 & 0.11 & 2.5 & 3.1 \\
\hline S5 & -37 & $8-93$ & 0.5 & 5.7 & 0.14 & 2.7 & 3.1 \\
\hline S5 & -37 & $5-94$ & 1.8 & 5.6 & 0.14 & 2.6 & 3.0 \\
\hline S5 & -46 & $1-93$ & 4.2 & 5.4 & 0.18 & 2.7 & 2.7 \\
\hline S5 & -46 & $8-93$ & 0.5 & 5.3 & 0.10 & 2.5 & 2.9 \\
\hline S5 & -46 & $5-94$ & 2.9 & 5.6 & 0.13 & 2.6 & 2.9 \\
\hline BW21 & -8 & $2-93$ & 1.6 & 5.1 & 0.14 & 2.5 & 2.7 \\
\hline BW21 & -8 & $8-93$ & 1.1 & 5.1 & 0.13 & 2.4 & 2.7 \\
\hline BW21 & -8 & $5-94$ & 3.0 & 5.2 & 0.19 & 2.5 & 2.7 \\
\hline BW21 & -23 & $2-93$ & 2.4 & 5.1 & 0.16 & 2.5 & 2.6 \\
\hline BW21 & -23 & $8-93$ & 2.1 & 5.1 & 0.16 & 2.5 & 2.6 \\
\hline BW21 & -23 & $5-94$ & 2.5 & 5.2 & 0.20 & 2.5 & 2.6 \\
\hline BW21 & -48 & $2-93$ & 0.5 & 5.1 & 0.12 & 2.6 & 2.4 \\
\hline BW21 & -48 & $8-93$ & 5.7 & 5.0 & 0.09 & 27 & 2.2 \\
\hline BW21 & -48 & $5-94$ & -0.8 & 4.9 & 0.11 & 2.5 & 2.4 \\
\hline
\end{tabular}

